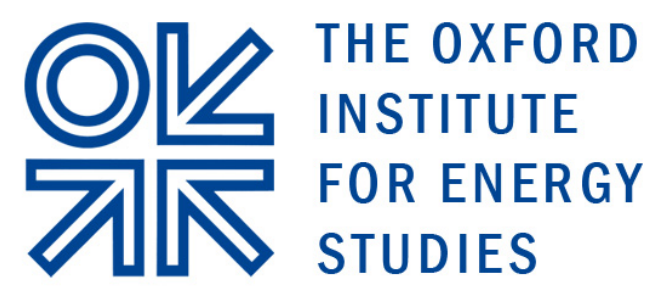

A RECOGNIZED INDEPENDENT CENTRE OF THE UNIVERSITY OF OXFORD

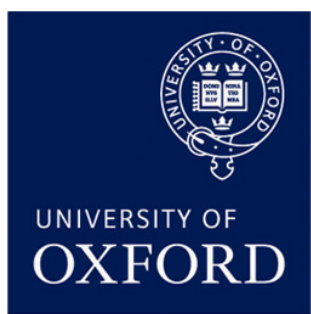

\title{
The Strategic Implications of Russia's Eastern Oil Resources
}

\author{
James Henderson ${ }^{1}$
}

\author{
WPM 41
}

January 2011

\footnotetext{
${ }^{1}$ Dr. James Henderson has been analysing the Russian oil and gas industry for the past 15 years. Having been Head of Energy for Wood Mackenzie Consultants in the mid-1990s he moved to Moscow as Head of Oil \& Gas Research for Renaissance Capital in 1997 and in 1999 became Head of Equity Research. He returned to the UK in 2002 and is currently Head of Russia for Lambert Energy Advisory in London as well as a Senior Visiting Research Fellow at OIES. He completed his doctoral thesis on partnership in the Russian oil and gas industry at the University of London and received his PhD in 2010.
} 
The contents of this paper are the authors' sole responsibility. They do not necessarily represent the views of the Oxford Institute for Energy Studies or any of its members.

Copyright C 2011

Oxford Institute for Energy Studies

(Registered Charity, No. 286084)

This publication may be reproduced in part for educational or non-profit purposes without special permission from the copyright holder, provided acknowledgment of the source is made. No use of this publication may be made for resale or for any other commercial purpose whatsoever without prior permission in writing from the Oxford Institute for Energy Studies.

ISBN

$978-1-907555-23-7$ 


\section{Contents}

Acknowledgements ...................................................................................................................vi

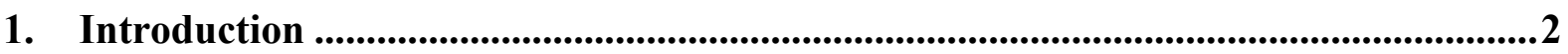

2. Russia's Energy Relations with the Asia-Pacific Region .........................................3

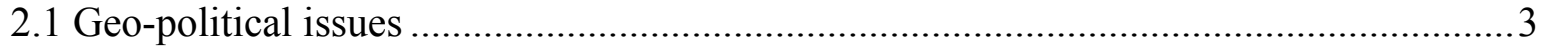

2.2 Supply and Demand for Oil in the Asia-Pacific Region .............................................. 4

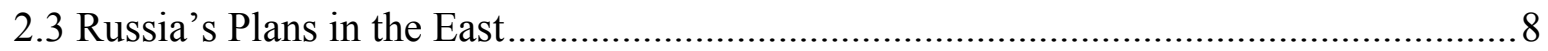

3. The History of the East Siberia-Pacific Ocean Pipeline (ESPO) ..................................11

4. Russian Oil Company Strategies in the East to Date ...................................................14

5. Government support for East Siberia hydrocarbon developments.............................16

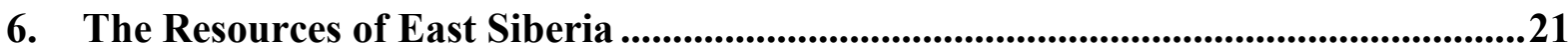

7. The Activities and Assets of Key Corporate Players in East Siberia and the Far

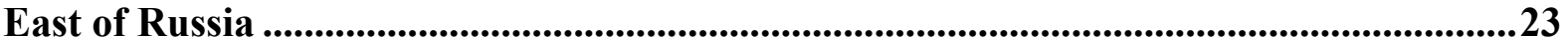

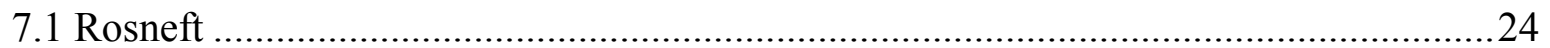

Vankor: Rosneft and Eastern Russia's most important upstream asset ..........................27

Rosneft's other East Siberian and Far East assets.........................................................29

Rosneft represents Russia's oil interests on Sakhalin Island ............................................ 31

Conclusions on Rosneft in East Siberia and the Far East................................................. 33

Other Key Oil Players in East Siberia and the Far East................................................ 35

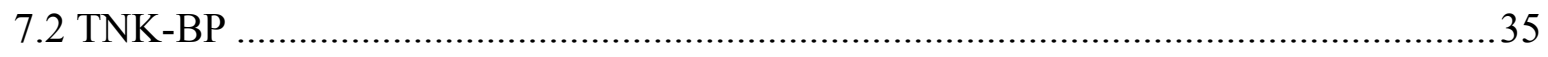

Conclusions on TNK-BP as an East Siberian oil producer............................................... 38

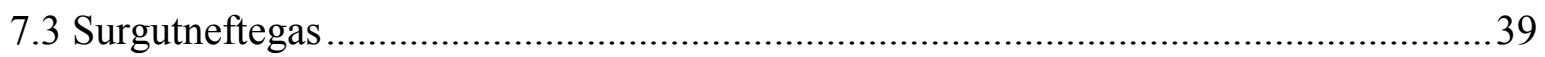

Conclusions on Surgutneftegas in East Siberia ................................................................ 41

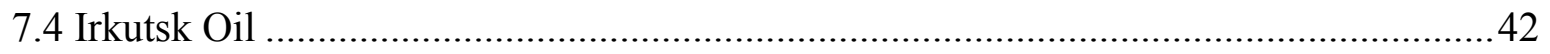

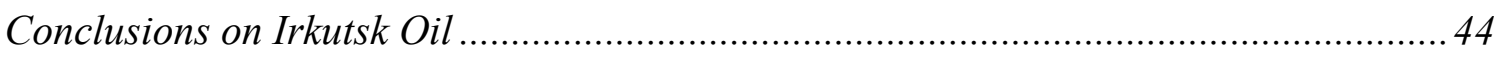

7.5 Slavneft (jointly owned by GazpromNeft and TNK-BP as a 50:50 Joint Venture).......45

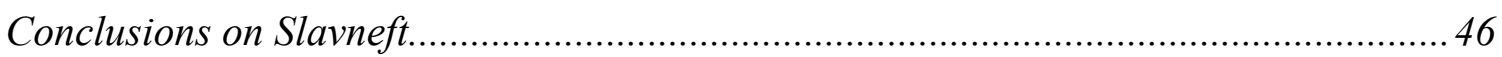

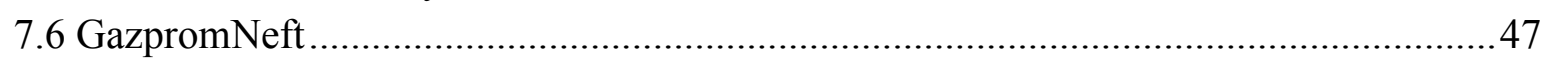

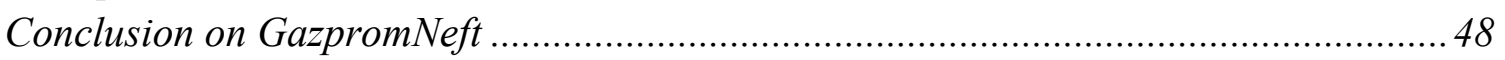

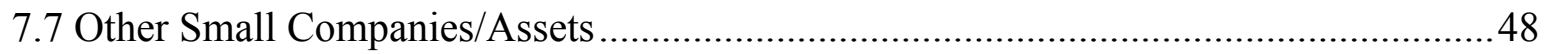

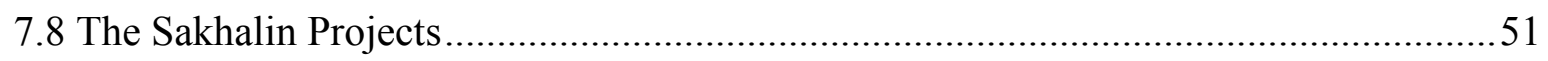

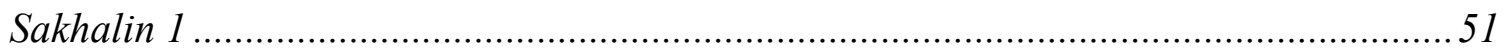

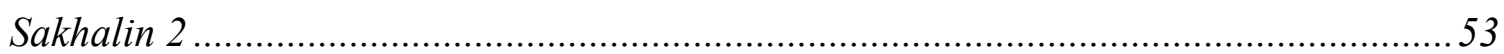

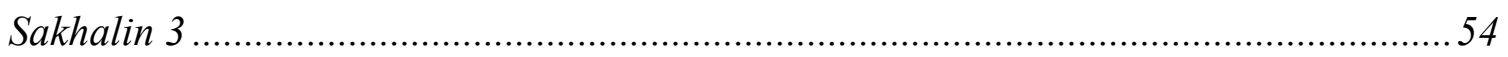

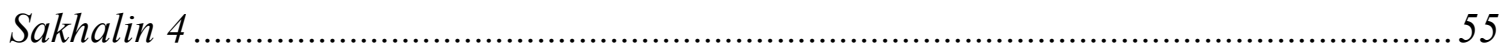

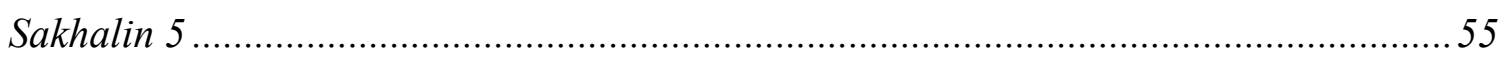

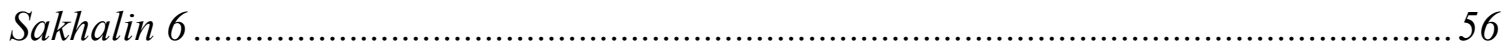

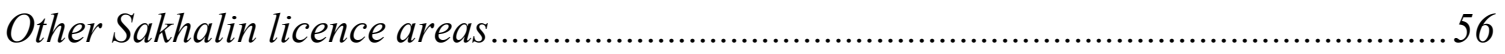

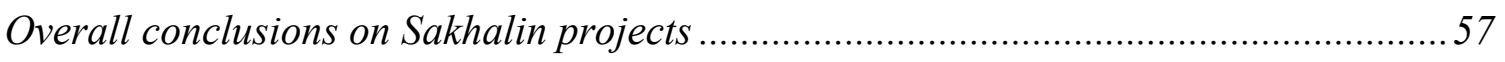

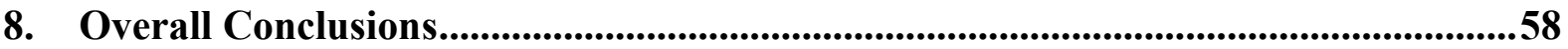


8.1 Russian Oil Supply from East Siberia and the Far East regions .................................58

8.2 Key risks to the potential growth of oil production in the Russian East ........................63

8.3 The potential impact of East Siberian crude on Russia's overall production and exports

Appendix 1: Definitions of East Siberia and Far East of Russia ....................................70

Appendix 2: Reserve Classification in Russia .................................................................................72

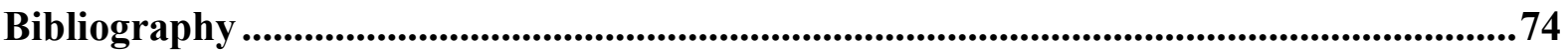

\section{Figures}

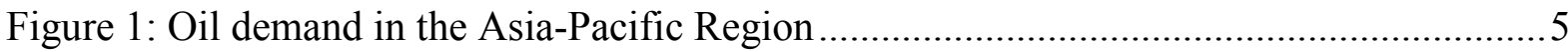

Figure 2: Oil supply, demand and imports in the Asia-Pacific Region ..................................6

Figure 3: Forecast of growing oil import requirements in the Asia-Pacific region ..................6

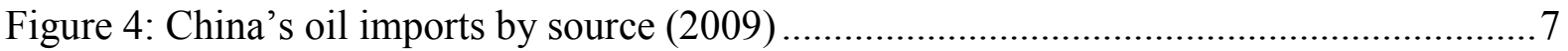

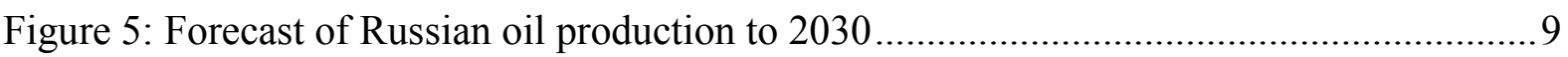

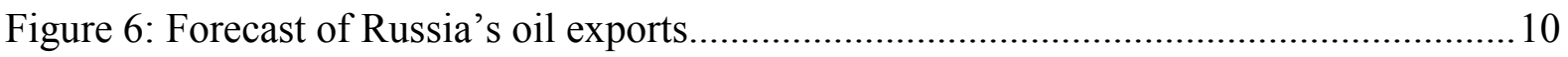

Figure 7: Split of Russia's crude oil exports to Asia in 2009 ............................................. 10

Figure 8: Sources of Russian crude volumes exported to Asia-Pacific market ...................... 11

Figure 9: Sources of Rosneft's East-facing crude oil exports............................................. 15

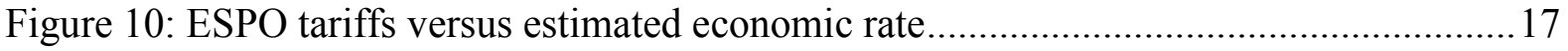

Figure 11: East Siberia refineries' 2009 throughput and total capacity................................. 19

Figure 12: Impact of recent tax changes on economics of East Siberia oil exports ...............21

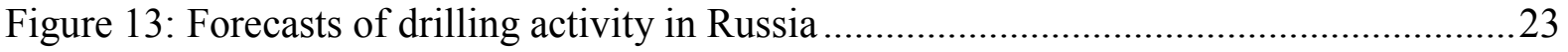

Figure 14: Split of Rosneft's reserves and resources in East Siberia and the Far East............26

Figure 15: Split of Rosneft's Russian refining capacity (mm tonnes per annum) ..................26

Figure 16: Rosneft's potential production from East Siberia and the Far East to 2030 ..........34

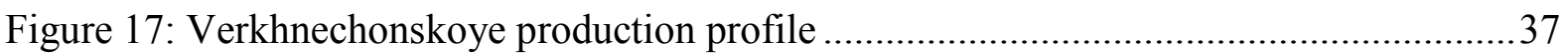

Figure 18: TNK-BP's production potential from East Siberia ............................................ 39

Figure 19: Potential output from Surgutneftegas' East Siberian fields ................................. 41

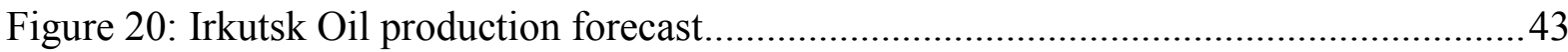

Figure 21: Slavneft's potential East Siberian oil production .............................................. 47

Figure 22: Potential output from Dulisma and Sredne Botuobinskoye fields ........................50

Figure 23: Potential output from Sakhalin Island projects ..................................................57

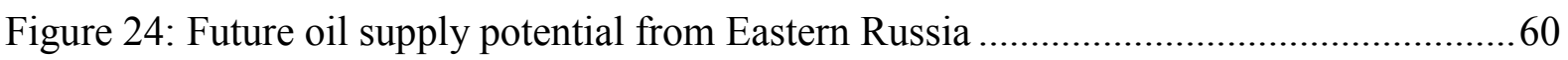


Figure 25: Eastern Russia oil production by company 62

Figure 26: Eastern Siberia oil production and ESPO capacity .............................................66

Figure 28: ESPO crude exports by destination (December 2009 to October 2010) ................68

\section{Tables}

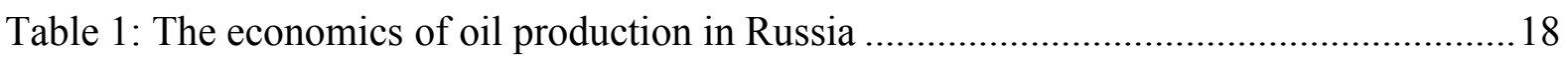

Table 2: Reserve estimates for East Siberia and the Far East of Russia...............................22

Table 3: Fields in East Siberia granted export tax reduction ................................................2

Table 4: Rosneft's Upstream Asset Base in Eastern Russia .................................................25

Table A-1: Key differences between Russian and international reserve methodologies..........73

\section{Maps}

Map 1: The route of the East Siberia-Pacific Ocean (ESPO) pipeline.................................. 13

Map 2: Vankor field location with surrounding Rosneft licences .......................................29

Map 3: Rosneft's portfolio of assets in the South of East Siberia ..........................................30

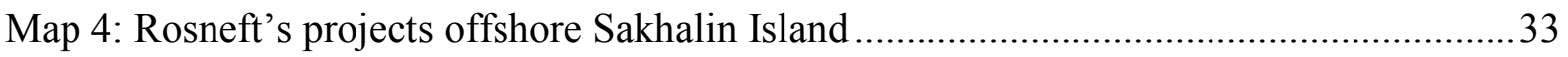

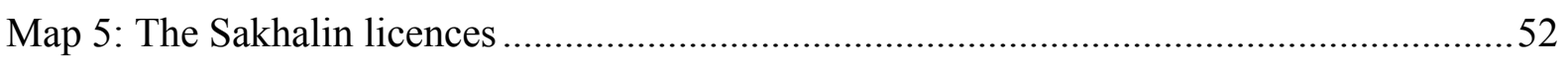

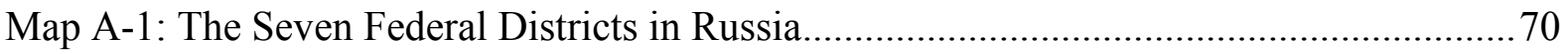

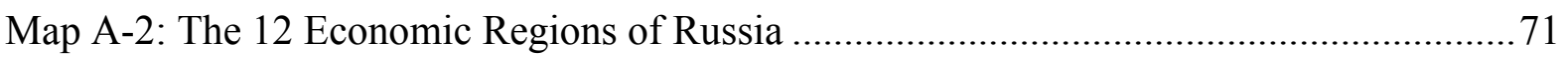




\section{Abbreviations and Units of Measurement}

$\begin{array}{ll}\text { bbls } & \text { Barrels } \\ \text { bcm } & \text { Billion cubic metres } \\ \text { bcma } & \text { Billion cubic metres per annum } \\ \text { bn bbls } & \text { Billion barrels } \\ \text { boepd } & \text { Barrels of oil equivalent per day } \\ \text { bpd } & \text { Barrels per day } \\ \text { E\&P } & \text { Exploration and Production } \\ \text { ESPO } & \text { East Siberia - Pacific Ocean (Pipeline) } \\ \text { FSU } & \text { Former Soviet Union } \\ \text { IOC } & \text { International Oil Company } \\ \text { kboepd } & \text { Thousands of barrels of oil equivalent per day } \\ \text { kbpd } & \text { Thousands of barrels per day } \\ \text { km } & \text { Kilometres } \\ \text { mm bbls } & \text { Million barrels } \\ \text { mcm } & \text { Thousands of cubic metres } \\ \text { mmboepd } & \text { Millions of barrels of oil equivalent per day] } \\ \text { mmbpd } & \text { Millions of barrels per day } \\ \text { mmcm } & \text { Millions of cubic metres } \\ \text { mmt } & \text { Millions of tonnes } \\ \text { mmtpa } & \text { Millions of tonnes per annum } \\ \text { P\&P } & \text { Proved and Probable } \\ \text { PSA } & \text { Production Sharing Agreement } \\ \text { ROC } & \text { Russian Oil Company } \\ \text { RUR } & \text { Russian roubles } \\ \text { tcm } & \text { Trillion cubic metres } \\ & \end{array}$

\section{Conversion Factors}

\begin{tabular}{|clcl|}
\hline & & Equals & \\
\hline 1 & tonne oil & 7.3 & barrels of oil equivalent \\
1 & tonne condensate & 8.0 & barrels of oil equivalent \\
& & & \\
1 & bcm gas & 6.6 & mm barrels of oil equivalent \\
1 & bcm gas & 35.3 & billion cubic feet of gas \\
1 & bcm gas & 0.9 & mm tonnes of oil equivalent \\
\hline
\end{tabular}

Source: BP Statistical Review 


\section{Acknowledgements}

I would like to thank my colleagues at the OIES for their help with this research. In particular I am very grateful for the support and comments provided by Bassam Fattouh, the Director of the Oil Programme at OIES, and also for the suggestions made by Jonathan Stern, Shamil Yenikeyeff and Keun-Wook Paik. I would also like to thank my editor, Judy Mabro, for her detailed corrections and comments.

I would also like to acknowledge the contribution of my colleagues at Lambert Energy Advisory, who as always have been generous with their time and support. In particular, I would thank, Olga Mordvinova for her contribution and for reading and commenting on an entire first draft of the paper.

Thanks also to the many industry executives, consultants and analysts with whom I have discussed this topic, but as always the results of the analysis remain entirely my responsibility. 


\section{Introduction}

Russian oil exports have historically been focused on western markets, with the country's huge trunk pipelines taking all the crude not used in domestic refineries from Siberia into the heart of Europe or to Russia's Baltic or Black Sea coasts for onward transport into the global oil markets. However, Russia's position in European and other western markets has now matured to a level where further expansion will be difficult to achieve, and as a result the rapid growth of the Asia-Pacific economies, and in particular China, over the past two decades has led to a re-focusing of Russia's strategic and energy interests. The oil and gas resources of East Siberia and the Far East of Russia have long been known about, but a lack of investment in them in the post-Soviet era has reflected a general sense of the decline in those regions over the past twenty years. However, a number of factors have now led the Russian Administration to change its strategy in the East. Firstly, at a geo-political level there is a clear desire to promote economic activity in the Russian East in order to halt the depopulation of the region and to counter the strategic vulnerability caused by the perceived threat from a rapidly growing superpower on the southern borders. Secondly, from an oil industry perspective, there is a need to supplement production from other (western) regions of Russia, which is forecast to go into gradual decline over the next twenty years. And thirdly, there is a clear economic incentive to exploit the potential for a significant boost to hydrocarbon export sales that is offered by the rapidly expanding energy demand in the AsiaPacific region, and in particular in China.

This paper therefore examines the renewed interest in investment in the oil resources in East Siberia and the Far East. The key catalyst required to encourage increased activity in the sector has always been regarded as the construction of pipeline infrastructure to allow any oil from new fields to be moved to market, and the Russian State has now provided this incentive via its wholly owned transport company Transneft, which opened the East SiberiaPacific Ocean pipeline in December 2009. This pipe not only provides a link to Russia's Pacific coast, but as of January 2011 has also provided a direct link to the world's fastest growing oil market, China. Although the initial capacity of the ESPO is only 600,000 bpd it has an ultimate planned capacity of $1.6 \mathrm{mmbpd}$, of which $300,000 \mathrm{bpd}$ will initially flow to China, rising to $600,000 \mathrm{bpd}$ over the next decade. This paper will examine the strategic importance of this new pipeline route, both in terms of Russia's relations with China but also in the context of the impact of newly emerging Russian crude on the Asia-Pacific oil market. In particular it will focus on the ability of Russia to increase production from its eastern regions to fill the full capacity of the ESPO, and will examine the plans of all the companies 
involved in the development of licences and fields from Krasnoyarsk in the west to Sakhalin Island in the east, looking in detail at the specific assets that will provide the bulk of Russia's oil exports to eastern markets. The paper will also discuss the fiscal incentives that the Russian State is starting to provide in order to encourage companies to make the long-term investment decisions needed to develop oil fields in the region, and will also provide estimates by company of the potential amount and timing of oil production that could possibly emerge as a result. The overall goal will therefore be to analyse the potential for Russia's eastern territories to produce sufficient oil to balance the gradual decline expected in the west of the country, thereby allowing the Russian oil industry to meet the government's overall target for production in 2030 of c. $10 \mathrm{mmbpd}$. Further it will also explore the opportunity for Russian exports to make a greater contribution to the crude mix supplying demand in the Asia-Pacific region as the country's crude oil is transported from its eastern borders via the expanding pipeline infrastructure.

\section{Russia's Energy Relations with the Asia-Pacific Region}

\subsection{Geo-political issues}

Discussion about exports of oil and gas from Eastern Russia to the countries of the AsiaPacific region has been ongoing since the 1970s, when the Soviet authorities recognised the potential for its eastern territories to provide a significant supplement to the country's West Siberian output (Poussenkova N. , 2007, p. 7). However, the catalyst for action did not occur until the late 1990s when the Yukos oil company, then controlled and run by Mikhail Khodorkovsky, first anticipated the opportunity to initiate an eastern export programme (Olcott \& Petrov, 2009, p. 18). Despite disagreements on the exact direction of a pipeline route, by 2001 the development of a feasibility study on a Russia-China pipeline had been sanctioned by Yukos, Transneft and CNPC, although Transneft was also keen to consider a pipe stretching the entire distance to Russia's Pacific coast. The debate was finally concluded by then Prime Minister Kasyanov, who in 2003 opted to effectively do both projects, approving the construction of a pipeline from Angarsk in Irkutsk to Nakhodka on the Pacific Coast, with a branch line built to the Chinese border as a spur. However, the subsequent fall of the Kasyanov government and the arrest of Khodorkovsky combined with the bankruptcy of Yukos almost immediately undermined any implementation plans.

The problems created by instability in the domestic political arena were compounded by uncertainties surrounding Russia's east-facing foreign policy, in particular with regard to two of the major potential customers of Russian energy resources, Japan and China. The situation 
with Japan is easier to describe, but harder to resolve as it centres on a territorial dispute that has prevented the two countries signing the peace treaty that ended the Second World War. In summary Soviet forces occupied the South Kuril Islands to the north of Japan in 1945, claiming to have re-taken lands lost to Japan at the end of the Russia-Japan war of 1904/05, but Japan has always argued that the treaties signed after the Second World War did not grant sovereignty to the Soviet Union. The dispute was inherited by Russia after the fall of the Soviet Union and is focused on four islands regarded by Japan as the "Northern Territories" but which are now formally governed as part of the Sakhalin oblast. Although the diplomatic debate might appear somewhat minimal, it has nevertheless provided an under-current of unease in Russo-Japanese relations and has inhibited economic relations between the countries, undermining, for example, a Japanese offer to finance the ESPO pipeline route to the Pacific Ocean in the mid-2000s. Indeed, even as recently as November 2010 a visit by Russian president Dmitry Medvedev to the South Kuril island of Kunashir ${ }^{2}$ caused a diplomatic scandal, with politicians in both countries keenly aware of the need to play to a domestic audience which would regard any concession as a sign of unacceptable weakness. As a result, Russia has always been reluctant to commit to the development of its Eastern resources if Japan has been the likely major customer.

The growth of the Chinese economy should have provided the comfort that a diverse customer base was available, but Russia's relations with its southern neighbour have also been riddled with complications based on geo-political and territorial concerns. China's economic growth has dwarfed that achieved by Russia, and the latter has always been concerned that in supplying the energy to fuel further growth it could just become a "resource appendage" providing further strength to its historic rival (Itoh, 2010). In addition, the demographic imbalance between the 6.5 million population of Eastern Russia compared with the 130 million people living in the Chinese regions directly across the border has encouraged fears about a gradual infiltration of Chinese influence into Russian territory. An ongoing border dispute that was not resolved until 2004 provided further ammunition for those politicians keen to emphasise the risks of growing Chinese strength in the region.

\subsection{Supply and Demand for Oil in the Asia-Pacific Region}

However, the growing commercial logic of exploiting the benefits of a link between a potentially huge supply of energy resources and a region with rapidly expanding energy

\footnotetext{
${ }^{2}$ Itar Tass World Service, 15 November 2010, RF-Japan relations normal again, territory dispute needs resolution, Moscow
} 
demand has finally become overwhelming. Data from the BP Statistical Review of World Energy 2010 demonstrates the dramatic growth in demand for oil in the Asia-Pacific region since 2000 , driven in particular by non-OECD countries. As Figure 1 shows, China has been the leading source of demand growth. With an economy expanding at $10 \%$ per annum between 2000 and 2008, oil demand has jumped by $81 \%$ over the past decade from 4.8 to 8.7 mmbpd. Indian oil demand has also leapt by $41 \%$ to $3.2 \mathrm{mmbpd}$ and, when combined with the growth in other non-OECD countries, this has more than offset stagnant or declining demand in Korea and Japan. As a result the Asia-Pacific region as a whole has seen oil demand grow by an average annual rate of $2.3 \%$ per annum to reach $26 \mathrm{mmbpd}$.

\section{Figure 1: Oil demand in the Asia-Pacific Region}

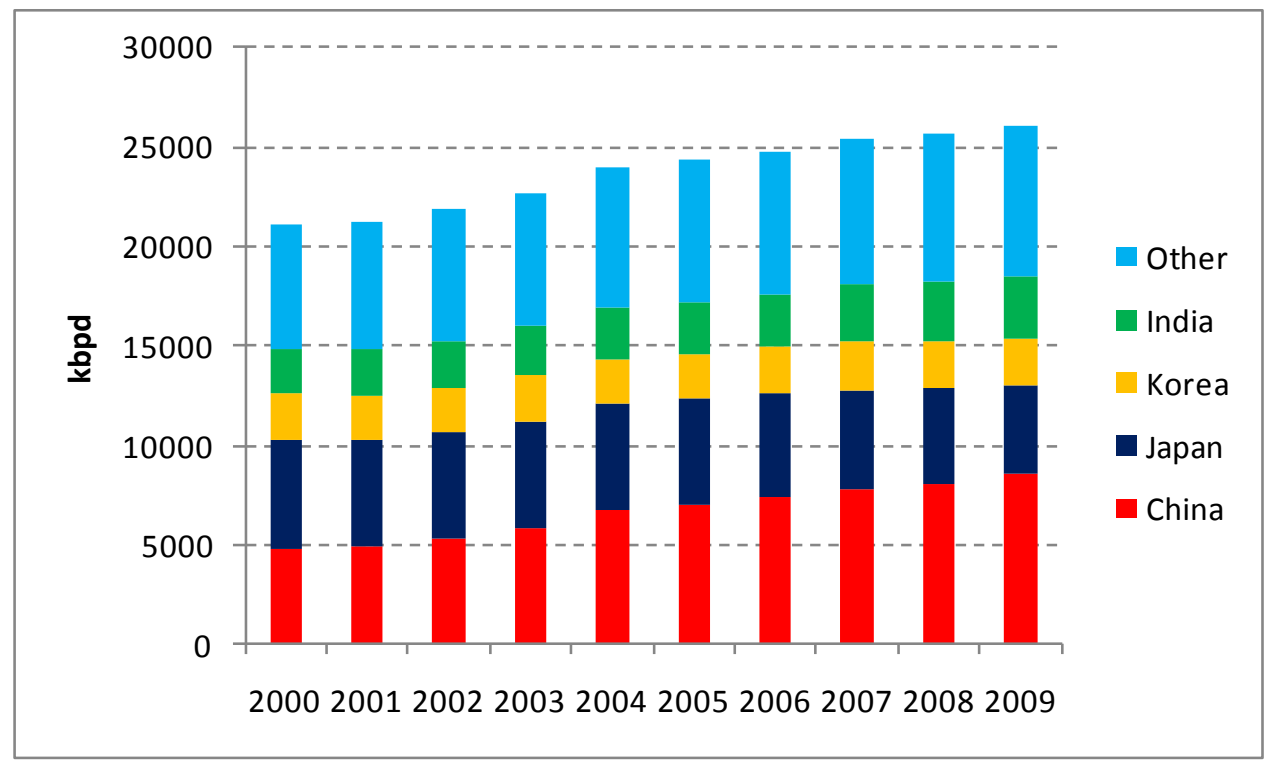

Source: BP Statistical Review of World Energy 2010

Over the same period oil production in Asia has remained almost flat, increasing by just $2 \%$ overall to $8 \mathrm{mmbpd}$, meaning that the region's import requirement has jumped dramatically. As shown in Figure 2, average annual growth of $3.4 \%$ per annum has seen total oil imports to Asia now reaching $18 \mathrm{mmbpd}$, with China both the region's largest consumer and importer, having overtaken Japan in 2009. 
Figure 2: Oil supply, demand and imports in the Asia-Pacific Region

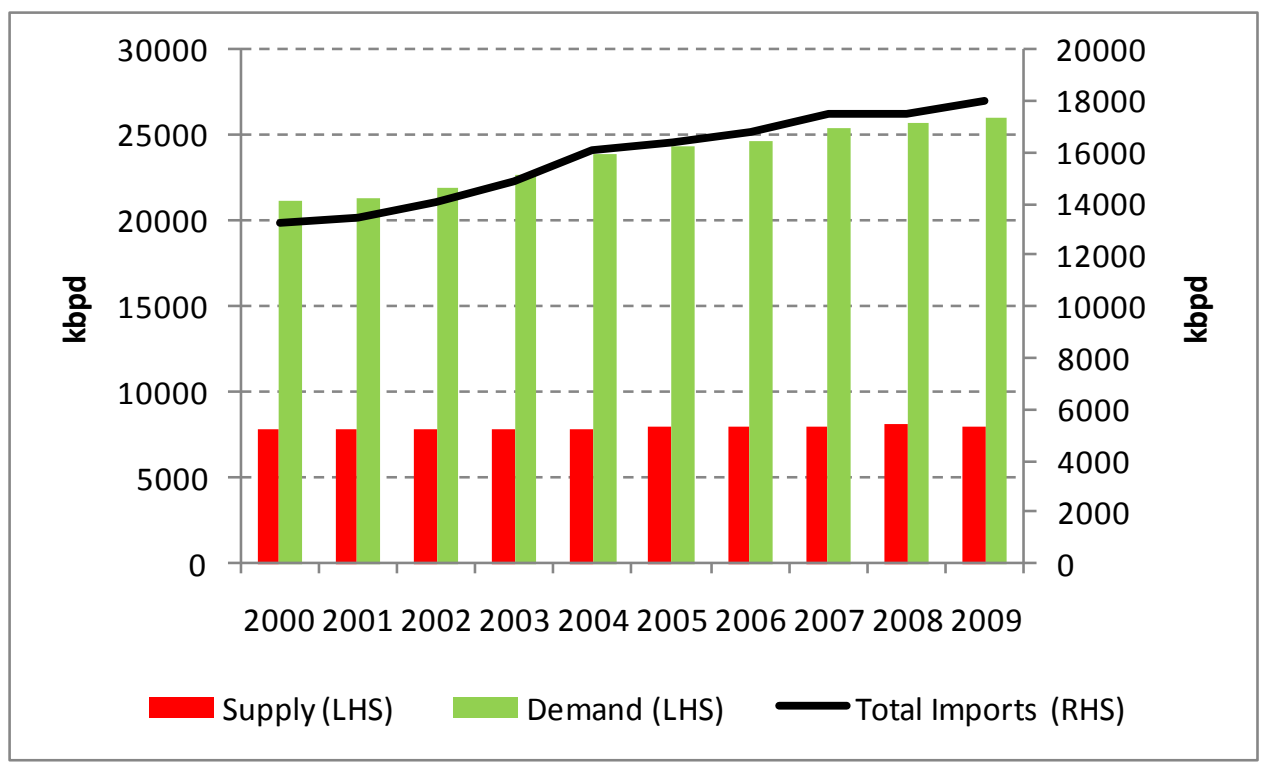

Source: Derived from data in the BP Statistical Review for World Energy 2010

Forecasts from the Energy information Administration (EIA) in the US suggest that this growth in import requirement is set to continue consistently over the next two decades or more. Figure 3 shows that, although OECD Asia oil demand is expected to remain flat, nonOECD Asia demand growth of $2.3 \%$ per annum combined with a $0.6 \%$ p.a. decline in oil production will lead to a doubling of the region's oil import requirement to over $33 \mathrm{mmbpd}$ during the period 2007- 2035.

Figure 3: Forecast of growing oil import requirements in the Asia-Pacific region

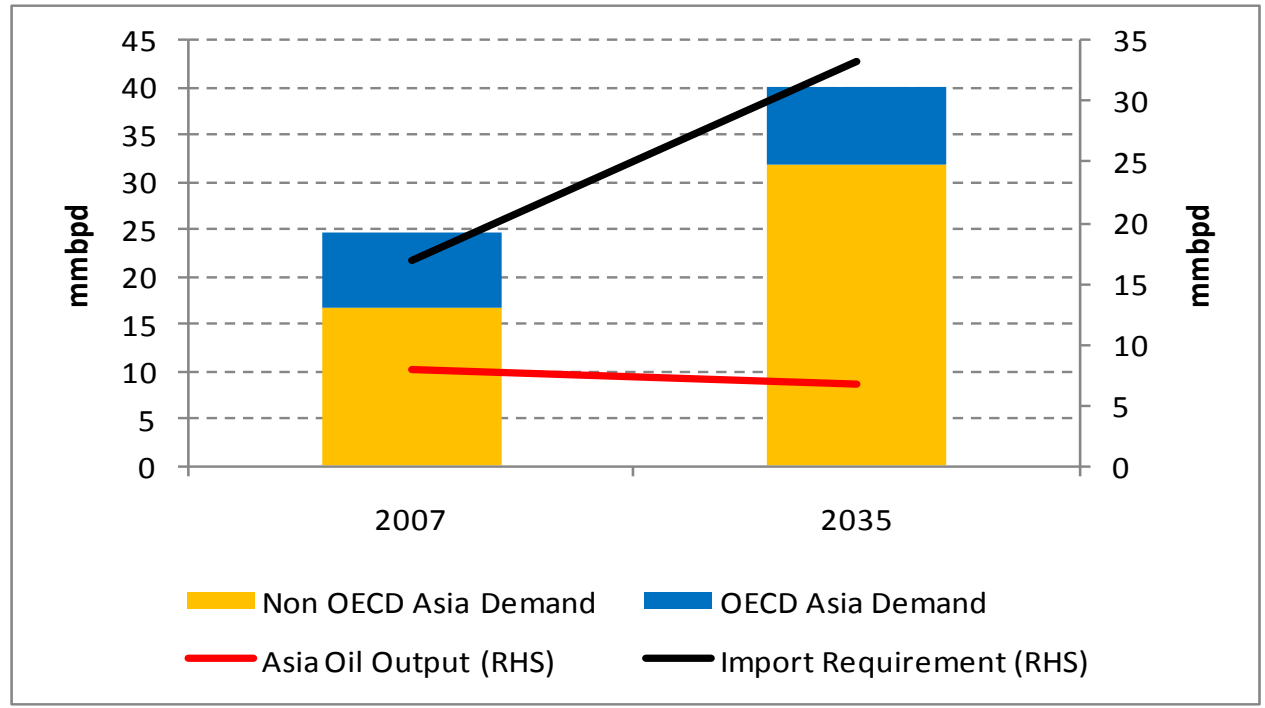

Source: EIA International Energy Outlook 2010 
The importance of China in this growth picture can hardly be understated. Over the two-year period between 2009-2011 Chinese oil demand is expected to have risen by $1.2 \mathrm{mmbpd}$, accounting for $37 \%$ of the global increase in demand, and by 2035 China's total oil demand could have more than doubled to $17 \mathrm{mmbpd}$. Given the limited scope for increased domestic upstream output, which has driven the recent surge in international expansion by the Chinese oil companies, the result could be a tripling of the country's import requirement to $13 \mathrm{mmbpd}$ over the next 25 years. A strategic focus of China's energy strategy has therefore been to establish secure and diverse sources of import supplies, with a particular focus on avoiding over-reliance on the Middle East. As shown in Figure 4, China already imports half of its oil from this region (EIA, 2010b, p. 7), while the OECD Pacific countries take an even higher $82 \%$ from the same source, making diversification of supply routes a key focus of energy strategy. International upstream investment is one potential tactic, with Chinese state oil companies aiming to have 4 mmbpd of overseas equity oil output by 2020 , while the offer of bi-lateral loans to secure oil supplies has also been used in partnership with Russia, Brazil, Venezuela, Kazakhstan and Ecuador. However, the availability of secure import infrastructure will also be vital, and as a result the construction of import pipelines has become a key goal, with the ESPO from Russia potentially being complemented by an additional 400,000 bpd line in the south from Myanmar (EIA, 2010b, p. 9).

Figure 4: China's oil imports by source (2009)

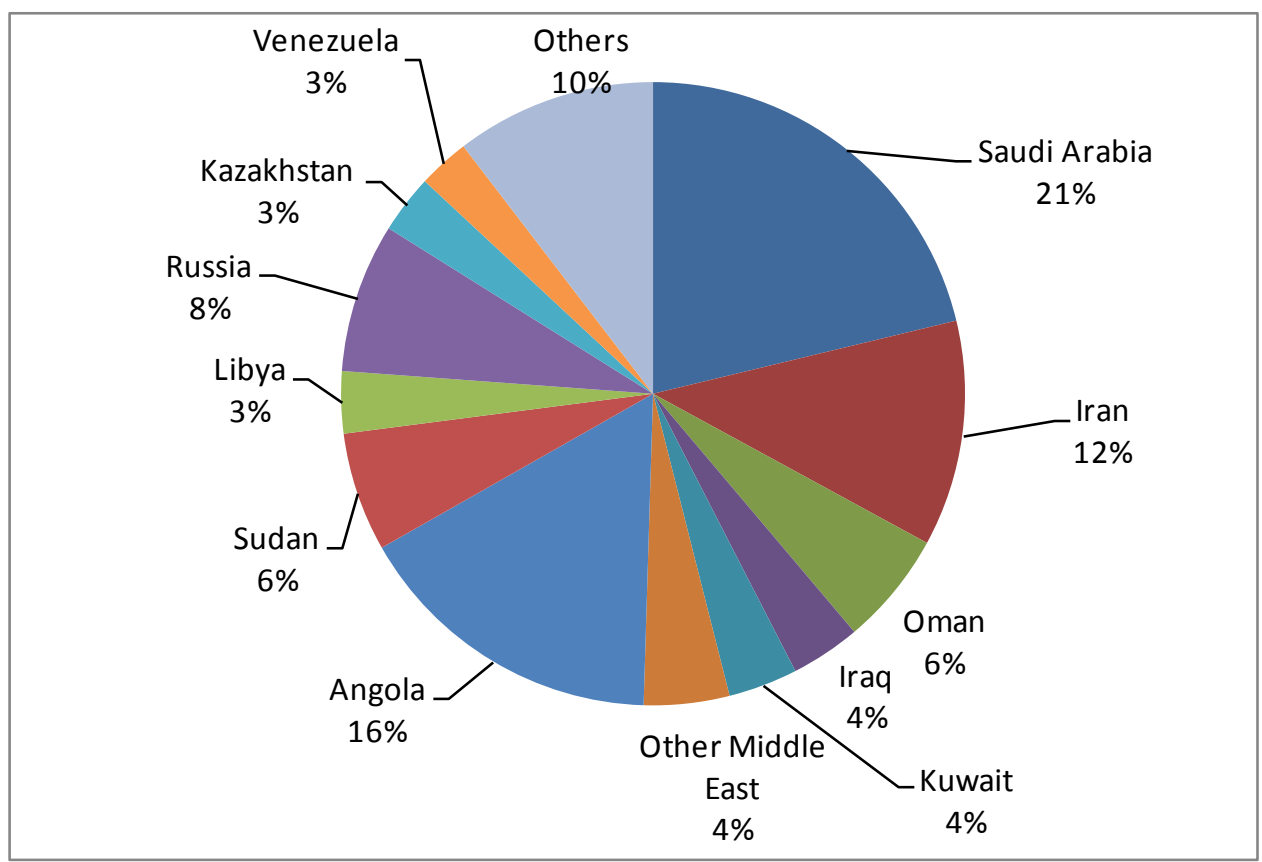

Source: EIA China Brief 


\subsection{Russia's Plans in the East}

The commercial logic of Russia playing a greater role in China and Asia's energy supply mix has become stronger not only because of a desire for the region to diversify its oil imports but also because of a balancing desire of the Russian Administration to reduce its reliance on western markets and to diversify east. This strategy has been driven by a number of factors including a) the need to balance the natural decline of oil output in West Siberia with growth from other regions; b) the political imperative to maintain Russia's domestic strength in its eastern regions in order to pre-empt any potential long-term issues of de-coupling from Moscow towards Beijing; c) the goal of re-generating Russia's eastern regions through investment in infrastructure, with the energy industry being at the forefront of this move; d) a desire to promote a multi-polar global geo-political order through closer ties with Asian countries, and in particular China, in order to balance the power of the US; e) a belief that the centre of global economic power is shifting east and that Russia has an opportunity to become a leading player in the region; and f) a realisation that economic and commercial relations can be an ideal way to underpin increased political links.

The regional aspect of this strategy was acknowledged by Russian President Dmitry Medvedev when he visited Khabarovsk near Vladivostok in July 2010 and stated that "the Asia-Pacific region possesses huge technological and investment potential, but it faces a deficit of raw materials and energy resources. Demand is growing. All this could give the eastern districts of Russia everything they badly need for their internal development." Meanwhile the specific numerical evidence was provided at the end of 2009 in the Russian Energy Strategy to 2030, a document that provides an official guide to government policy and direction. In it the growing importance of East Siberia and the Far East ${ }^{3}$ is very clear, as can be seen in Figure 5, which shows the forecast for Russian oil production to 2030.

Overall Russian oil output is forecast to grow by approximately $10 \%$ (from 9.75 to 10.75 mmbpd), but the split of that output is expected to change dramatically. The decline in core producing areas such as West Siberia and European Russia will to some extent be compensated for by growth in other western regions such as Timan Pechora and the Russian sector of the Caspian, but overall oil production in western Russia is expected to decline by around $1 \mathrm{mmbpd}$ over the next 20 years. Eastern Russia will therefore be the most important source of production growth, with output in East Siberia rising from zero in 2008 to 1.4-1.5 mmbpd by 2030 and with Far East Russia adding a further 600-700 kbpd. Overall Eastern

\footnotetext{
${ }^{3}$ For a specific definition of the East Siberia and Far East regions see Appendix 1
} 
Russia is expected to provide $20 \%$ of Russia's total oil production by 2030 , up from $3 \%$ in 2008.

Figure 5: Forecast of Russian oil production to 2030

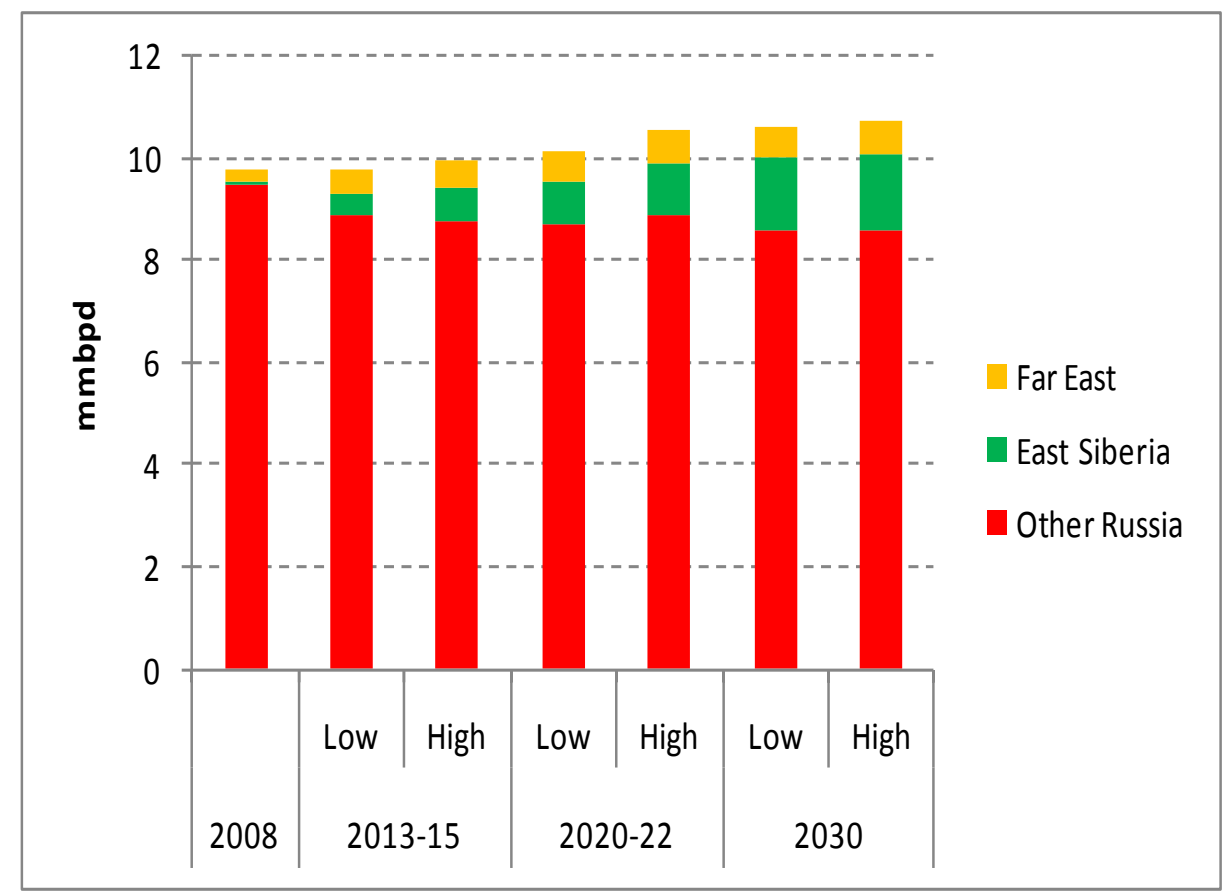

Source: Russian Energy Strategy to 2030

Even more significant will be the contribution of eastern markets for Russia's oil export sales, as their share of the total is expected to rise from $8 \%$ in 2008 to $25 \%$ by 2030 . Essentially, while overall exports are forecast to remain flat at around $5 \mathrm{mmbpd}$ (in the High Case Scenario ${ }^{4}$ ), east-facing exports will rise to $1.3 \mathrm{mmbpd}$ while west-facing sales will fall to $3.7 \mathrm{mmbpd}$ in a potentially clear demonstration of the re-focusing of Russia's commercial ties.

In 2009 Russia exported just under $500 \mathrm{kbpd}$ of crude oil to the Asia-Pacific market, equivalent to $12 \%$ of the country's total crude oil exports of $4.3 \mathrm{mmbpd}$. As shown in Figure 7 below, almost half of these exports went to China, with Korea and Japan being the other two key markets. The delivery methods for these various markets differed markedly, however, with the Chinese sales being sent via rail and supplied mainly by Rosneft, which in 2005/06 took over the export relationship with China (that had been started by Yukos) at the same time as it acquired Yukos' producing assets in the bankruptcy auctions. Other

\footnotetext{
${ }^{4}$ The Russian Energy Strategy provides High and Low Case forecasts for the periods 2013-2015, 2020-2022 and 2030. Figures 5 and 6 show the two forecasts for each time period as well as the historical data for 2008
} 
contributors to the Chinese sales included LUKoil and TNK-BP, but of the $241 \mathrm{kbpd}$ of total sales almost $180 \mathrm{kbpd}$ was accounted for by Rosneft.

Figure 6: Forecast of Russia's oil exports

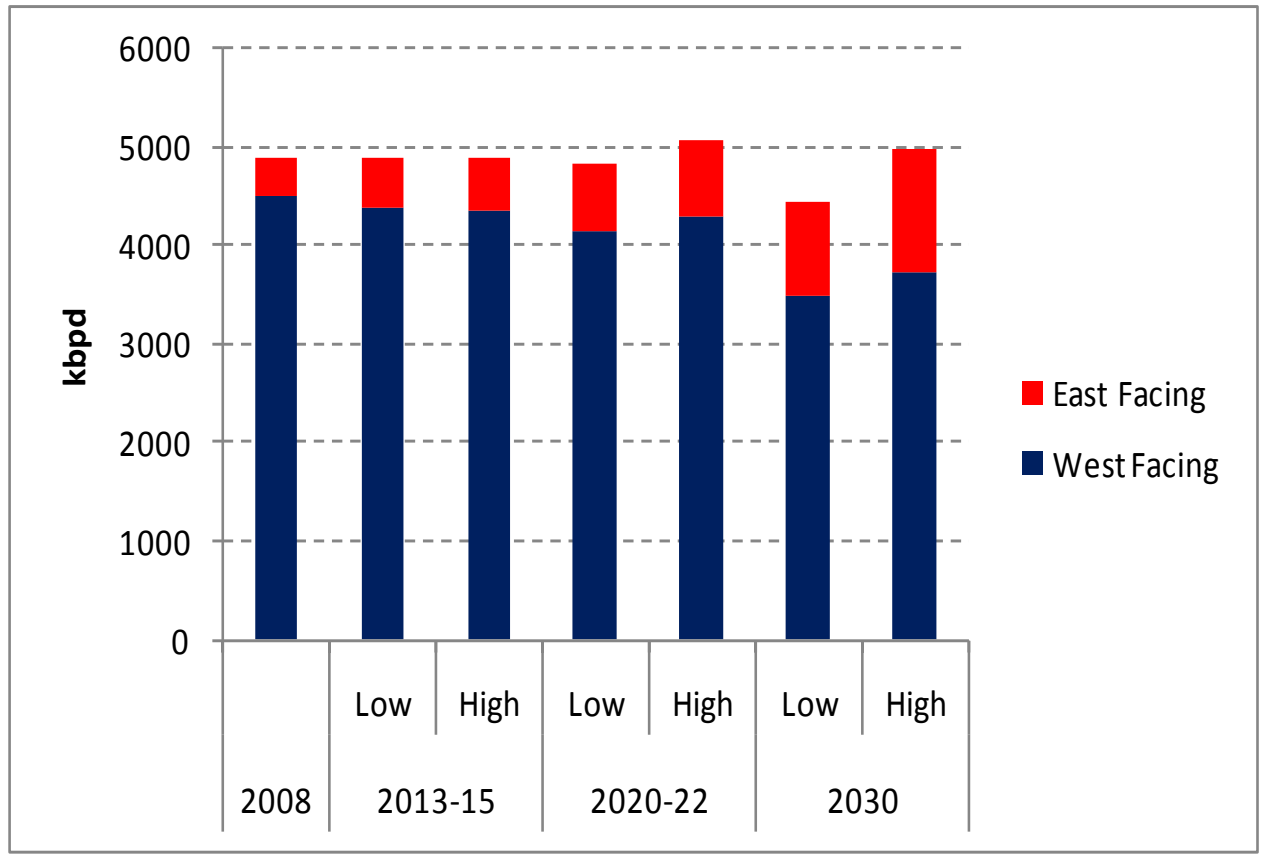

Source: Russian Energy Strategy to 2030

Figure 7: Split of Russia's crude oil exports to Asia in 2009

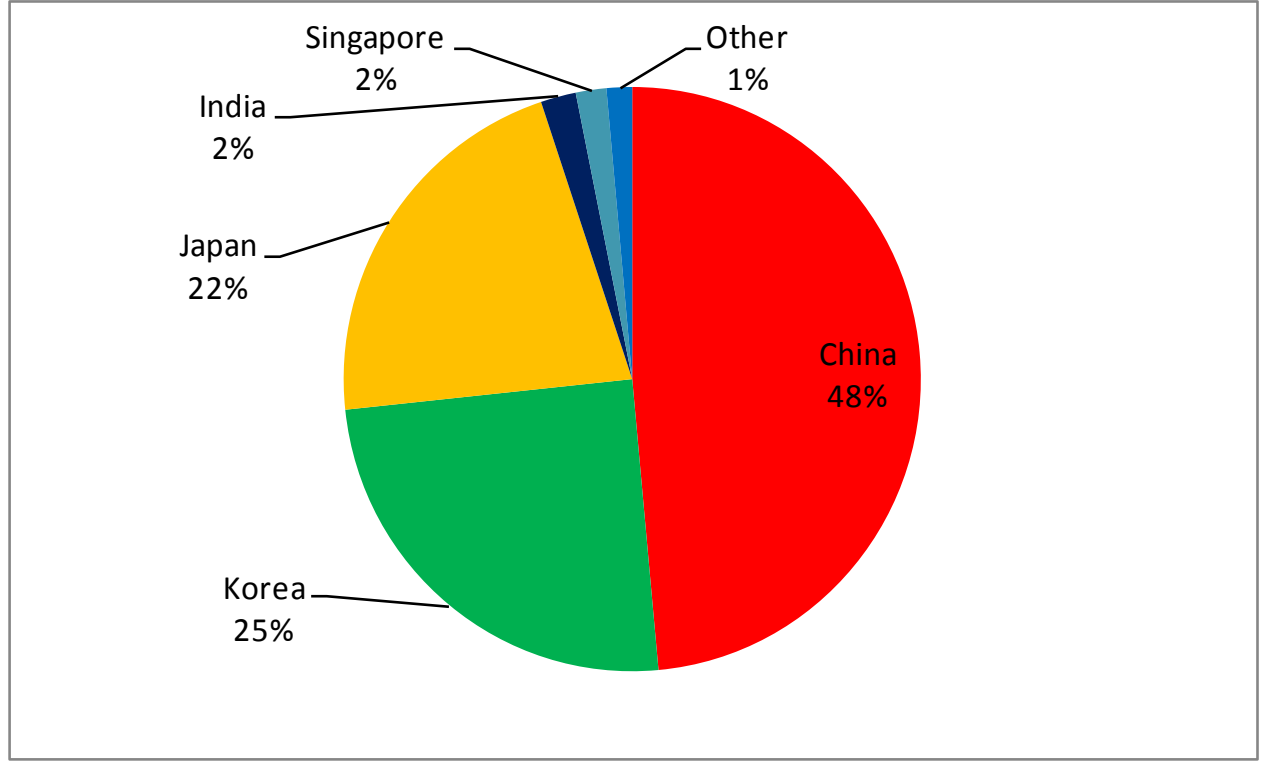

Source: Russian Federal Export Agency

The remainder of Rosneft's crude exports to Asian markets come from its $20 \%$ stake in the Sakhalin 1 project, where $165 \mathrm{kbpd}$ was produced and exported in 2009. This reflects the fact that Russia's exports to the rest of Asia (outside China) are sourced entirely from Sakhalin, 
where total oil production reached over $275 \mathrm{kbpd}$ in 2009 thanks to additional output from Gazprom and Shell's Sakhalin 2 project. Crude from the island is sent via tanker largely to the Korean and Japanese markets, and makes up more than half of Russia's total export volumes to the Far East (see Figure 8).

\section{Figure 8: Sources of Russian crude volumes exported to Asia-Pacific market}

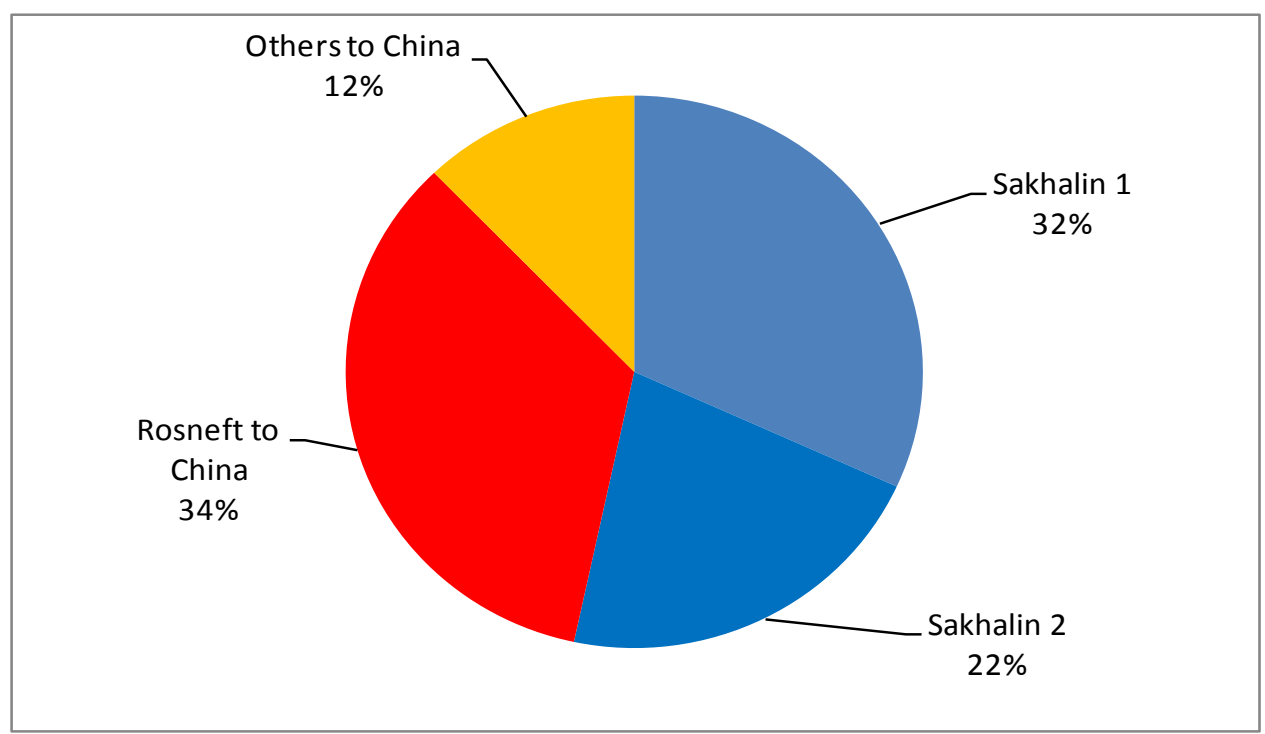

Source: Author's estimates based on data from Rosneft and Wood Mackenzie Consultants

The combination of Russia and Rosneft's desire to increase eastern production and sales with the willingness of China to increase its exposure to Russian imports and provide financing for their development and transport is likely to lead to the transformation of this export picture over the next decade. In particular the ongoing construction and expansion of the East Siberia-Pacific Ocean (ESPO) pipeline will mean that the overall level of exports could treble by 2020 , if the full capacity is utilised.

\section{The History of the East Siberia-Pacific Ocean Pipeline (ESPO)}

Following the fall of Yukos, the initial sponsor of the pipeline to China concept, Transneft was handed responsibility for the construction and management of the project. However, this confirmation concerning the operatorship of the pipeline did not end the controversy over its routing, with the debate focused on two issues - environmental and market access. The environmental issue, which concerned the proximity of the original route to Lake Baikal, was resolved in 2006 when then President Putin ordered the pipe to be moved $400 \mathrm{~km}$ to the north (Olcott \& Petrov, 2009, p. 20). This had the double advantage of reducing the contamination risk for the region's key source of fresh water and moving the pipeline route closer to some 
of the key fields that would help to fill it. However, the extra $120 \mathrm{~km}$ added to the overall distance did increase the cost by approximately $\$ 850$ million.

The question of market access and the priority of pipeline routing continued to hang over the project, however. Transneft had generally favoured a route to the far eastern coast of Russia, with an initial terminating point at Perevoznaia Bay, based on the logical argument that this would provide access to competing Asia-Pacific markets. Japan announced its support for this route as early as January 2003 (Itoh, 2010, p. 10), but Moscow's uncertain relationship with the Japanese authorities led to constant prevarication and a refusal to commit to a confirmed construction timetable. In the meantime, China's expanding oil import requirement, the growing reliance of Russian state oil company Rosneft on an expensive rail link for its Chinese exports, the increasing warmth of political relations between China and Russia and the attraction for Transneft of a shorter pipeline route all pointed towards a growing acceptance that China would need to be part of any export solution. This realisation was crystallised during the economic crisis of 2008/09 when the Chinese Administration provided a total of $\$ 25$ billion of loans to Russia (\$15 billion to Rosneft and \$10 billion to Transneft) to help alleviate short-tem financial concerns and to help fund long-term investments in oil infrastructure to supply eastern markets. Indeed the commitment to eastern exports was underwritten in the loan agreement, which Rosneft and Transneft agreed to repay in oil supply over a 20 -year period from $2011 .^{5}$ It was agreed that an average of 15 million tonnes per annum (mmtpa) would be supplied over two decades, with 9 mmtpa being provided by Rosneft and 6 mmtpa coming from Transneft. ${ }^{6}$ It was also agreed that, in order to ensure secure delivery of this crude, a spur of the ESPO would be built by Transneft from Skovorodino to the Russia-China border, and then China would finance the further extension of the line from the border to Daqing.

Once this agreement had been signed the routing of and commitment to the ESPO was essentially set in stone. As can be seen in Map 1, the pipeline starts from Taishet as an offshoot from the existing pipe from West Siberia via Tomsk to Angarsk. Phase 1, which was completed in December 2009, travels $2757 \mathrm{~km}$ as far as Skovorodino in the Amur region of Russia, and currently has a capacity of 600 kbpd (Platts, 2009, p. 2). From Skovorodino a 64 $\mathrm{km}$ spur line to the Russian border was completed in mid 2010, with a $960 \mathrm{~km}$ line inside

\footnotetext{
${ }^{5}$ Interfax Russia and CIS Oil \& Gas Weekly, 23 Feb 2009, “Russia, China sign \$25bn loans-for-crude deal”, Moscow

'Interfax China Weekly, 21 Sept 2010, "China not mulling changes to ESPO branch oil deliveries from 2011", Tianjin
} 
China then completing the route to Daqing with a capacity at present of $300 \mathrm{kbpd} .^{7}$ The line was tested in November 2010 and received first deliveries under the contract between CNPC and Rosneft as of January 1st 2011.

\section{Map 1: The route of the East Siberia-Pacific Ocean (ESPO) pipeline}

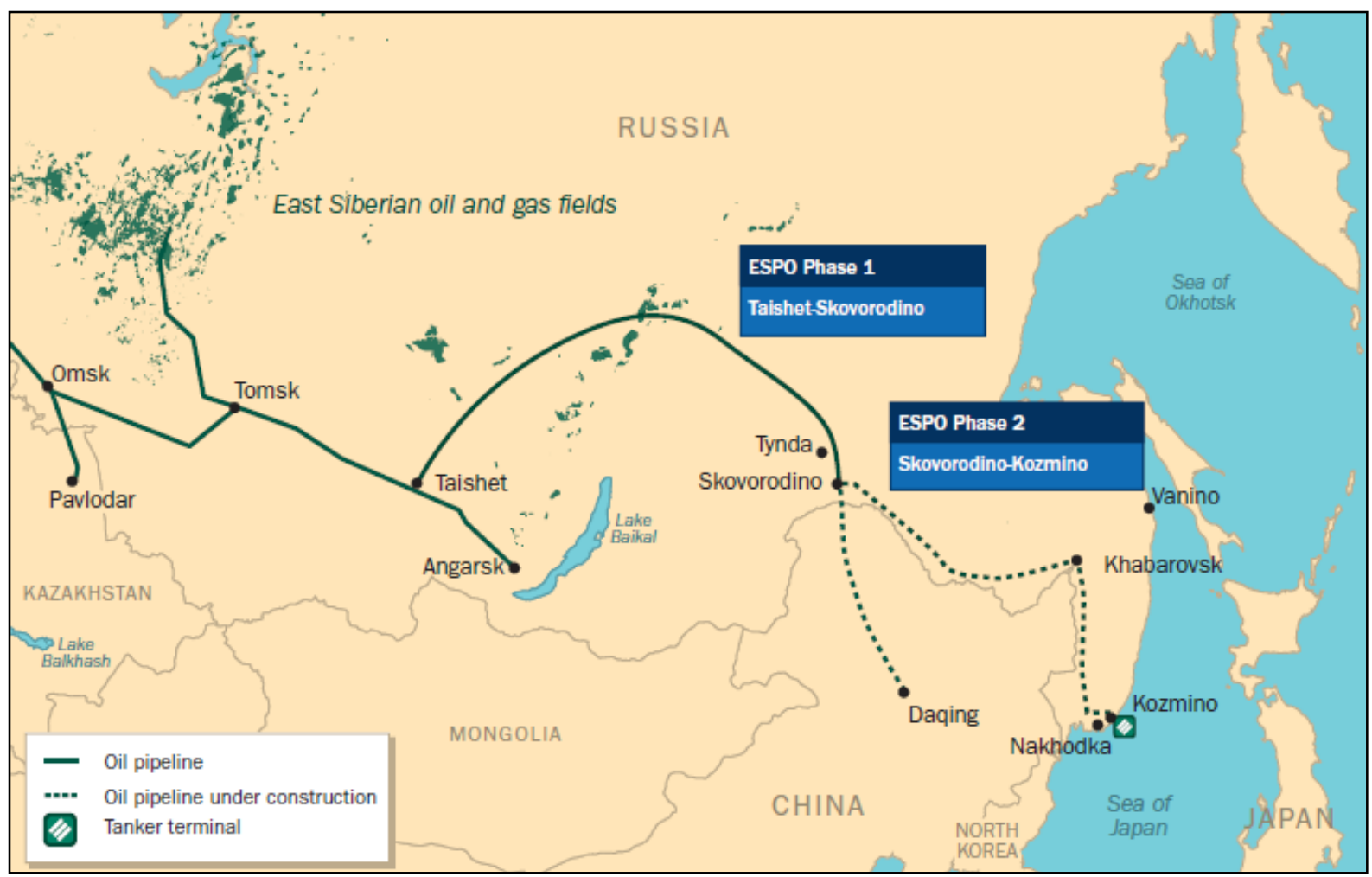

Source: Platts, ERINA

With $300 \mathrm{kbpd}$ of oil allocated to China from 2011, any remaining exports up to the current capacity at Skovorodino are transported to Kozmino Bay on the Pacific Coast by rail. The port facilities at Kozmino Bay exactly match the $300 \mathrm{kbpd}$ that could be available under Phase 1 of the ESPO construction plan, but Phase 2 is already under construction with a plan to extend the pipeline a further $2100 \mathrm{~km}$ from Skovorodino to the Pacific Coast and to expand the total capacity of the line to $1 \mathrm{mmbpd}$ (Platts, 2009). As of December 2010 half the pipeline had been laid, and the expectation is that by 2013 the full expansion of the new and existing line will have been completed. ${ }^{8}$ At the same time the option to expand the spur line into China is also available, with a doubling of throughput capacity to $600 \mathrm{kbpd}$ having been planned, although the Chinese authorities have stated that they are not yet ready to sanction

\footnotetext{
${ }^{7}$ Interfax Russia and CIS Oil \& Gas Weekly, 27 Oct 2010, "Transneft ready to pump processed oil to China through ESPO", Moscow

${ }^{8}$ Interfax Russia and CIS Oil \& Gas Weekly, 3 Dec 2010, "ESPO-2 pipeline nears half-way mark", Moscow
} 
any firm increase in their import commitment in the near term. ${ }^{9}$ Beyond 2013 the potential also exists to further expand the capacity of the entire system to $1.6 \mathrm{mmbpd}$, although this will be subject both to the availability of sufficient Russian production and to the levels of demand in China and the rest of the Asia-Pacific market.

\section{Russian Oil Company Strategies in the East to Date}

As has been noted in Figure 8, to date Russian crude supplies to Asian markets have come largely from two sources - the two current Sakhalin projects and Rosneft. Some other Russian oil companies, such as LUKoil and TNK-BP, have also contributed, but it is the example of Rosneft, as the largest East Siberian onshore supplier, which demonstrates how Russia's strategy towards supplying eastern markets is changing.

When Yukos first established itself as Russia's oil exporter to China in the early 2000s, its plans to sell up to $200 \mathrm{kbpd}$ were based on the production base that it established in the Tomsk region (via the acquisition of Tomskneft) supplemented in the early stages by oil from West Siberia (supplied by Yuganskneftegaz). ${ }^{10}$ The longer-term strategy was then to develop the fields acquired with East Siberian Oil in the Yurubcheno-Takhomskoye Zone and to replace rail-borne West Siberian oil with eastern crude transported through a new pipeline from Irkutsk to China (Allen \& Henderson, 2001, pp. 11-15).

Rosneft, having acquired Yukos' assets in 2005, has essentially continued this industrial strategy in anticipation of the completion of the ESPO pipeline. As can be seen in Figure 9 Rosneft's exports to Asia were largely sourced from West Siberia (in particular Tomskneft) from 2005-2008, but since then the gradual development of the company's East Siberian portfolio has seen production from the Vankor and Verkhnechonskoye fields take a larger share of export sales. Indeed with the inclusion of exports from Sakhalin 1 Rosneft now sources more than half of its eastern exports from fields in East Siberia and the Far East of Russia.

\footnotetext{
${ }^{9}$ Interfax Russia and CIS Oil \& Gas Weekly, 9 Sept 2010, “China not yet planning to take full 30mmtpa of ESPO branch oil", Moscow

${ }^{10}$ Interfax Russia and CIS Oil \& Gas Weekly, 4 Feb 2004, “CNPC, Yukos renew oil import contract at 10mmtpa from 2006", Moscow
} 


\section{Figure 9: Sources of Rosneft's East-facing crude oil exports}

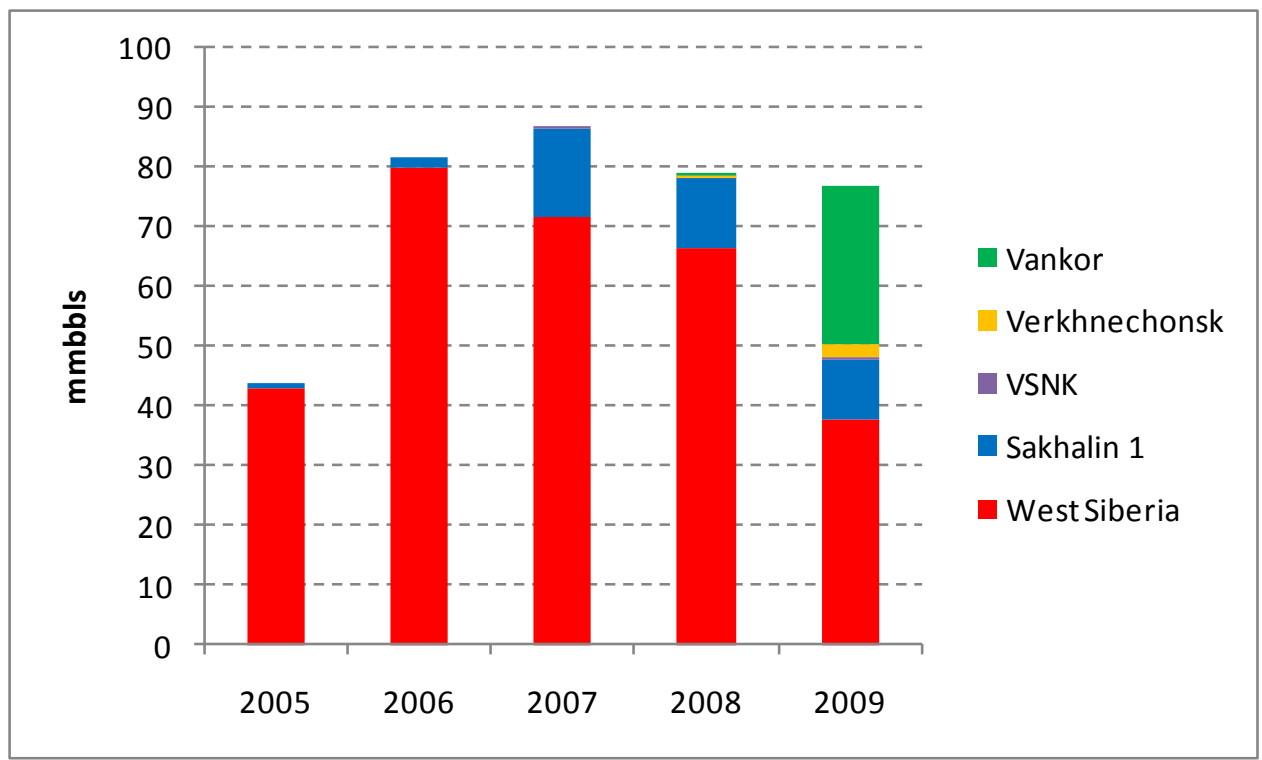

Source: Rosneft Databook Q3 2010

However, despite the apparent success of Rosneft's eastern expansion, the company's investment strategy towards the Vankor and Verkhnechonskoye fields has also reflected a wider industry view that the development of hydrocarbon resources in East Siberia requires significant government support to ensure its financial robustness. Former Rosneft CEO Sergei Bogdanchikov stated in June 2010 that peak production from the Vankor field would be limited to only half its potential 510,000 bpd if tax breaks were not introduced, ${ }^{11}$ while Sergei Brezitsky, a Vice President at TNK-BP, has noted that the difficulties of operating in East Siberia, including geological complexity as well as a lack of existing infrastructure, point towards the need for "tax incentive possibilities". ${ }^{12}$ A number of industry players have also noted that it is not only the level of tax incentives that is an issue, but also the length of time for which they will be applied. A quote from the Financial Times in September 2010 summarises the prevalent mood: "Uncertainty about the tax regime in East Siberia could slow investments that are essential if the oil industry, and the ESPO, are to flourish...We can't proceed with investment decisions without more clarity, says Peter O'Brien, vice president for finance and investment at Rosneft.",13

\footnotetext{
${ }^{11}$ Interfax Russia and CIS Oil \& Gas Weekly, 9 June 2010, “Oil cos. won't revise investment plans over increase in East Siberian export duty", Moscow

${ }^{12}$ Interfax Russia and CIS Oil \& Gas Weekly, 6 Sept 2010, "TNK-BP says developing East Siberia oil, gas deposits will require tax incentives", Moscow

${ }^{13}$ Financial Times, 12 Sept 2010, “Russia: Rising taxes cast shadow over eastern expansion”, Isabel Gorst, Moscow
} 


\section{Government support for East Siberia hydrocarbon developments}

Although Russian oil companies have mainly focused on tax relief as the most important form of government support needed in East Siberia, in fact the Russian Administration has provided a broader range of encouragement to the industry. Perhaps most importantly it has catalysed the strengthening of bilateral relations with China, the largest market for potential Russian oil and gas exports, with numerous visits and meetings over the past two to three years, including the symbolic choice of China as the first foreign visit by the newly elected Russian president Dmitry Medvedev in May 2008 (Portyakov, 2010). The celebration of 60 years of diplomatic relations between the two countries in 2009 also acted as a positive dynamic, with cultural and societal exchanges now underpinning a more pragmatic commercial relationship. Indeed a number of events that might previously have destabilised relations (the purchase of gas by China from Central Asia, the closing of the Cherkizov markets in Moscow, the sinking of a cargo ship with a Chinese crew near Nakhodka) have been dealt with in a calm and stable atmosphere, suggesting that much of the emotion has been taken out of the government-to-government dealings (Huasheng, 2010). It is certainly clear that from the Russian side the reason for this pragmatism is to encourage the hydrocarbon industry, with Prime Minister Putin stating of East Siberian oil developments and the ESPO "This is a vital project for us as we begin to diversify our sales of strategic raw materials." 14

A second strand of government support for the East Siberian oil industry has been in the development of the pipeline infrastructure that was essential to catalyse oil production. As described by TNK-BP in a review of its own East Siberia strategy, the decision to build the ESPO was a "milestone for East Siberian oil" (TNK-BP, 2008), with state-owned company Transneft playing the key role and investing 381 billion roubles (c. $\$ 12.5$ billion) in the first stage alone. ${ }^{15}$ However, the state has not only financed the construction of the pipe but has also arranged for the tariffs for its use to be set at subsidised levels. Transneft has estimated that the economic cost of transporting 1 tonne of oil through the ESPO system for a distance of $4857 \mathrm{~km}$ from Taishet to Kozmino Bay (including the $2100 \mathrm{~km}$ section that currently uses the railway) is approximately $\$ 130$, but this price has essentially been subsidised by the users of the entire Transneft system as they now pay a slightly higher tariff for the use of the

\footnotetext{
${ }^{14}$ Ibid

${ }^{15}$ Interfax Russia and CIS Oil \& Gas Weekly, 4 May 2010, “ESPO-1 costs 318bn roubles, ESPO-2 planned at 323bn", Moscow
} 
western part of the Russian oil pipeline system. ${ }^{16}$ The net result has been that the ESPO tariff (for the entire length of the route) was initially set at 1598RR/tonne (\$53/tonne), and although it rose to $1815 \mathrm{RR} /$ tonne (\$61/tonne) from December 12010 it still stands at a level less than half Transneft's estimated economic cost (see Figure 10).

\section{Figure 10: ESPO tariffs versus estimated economic rate}

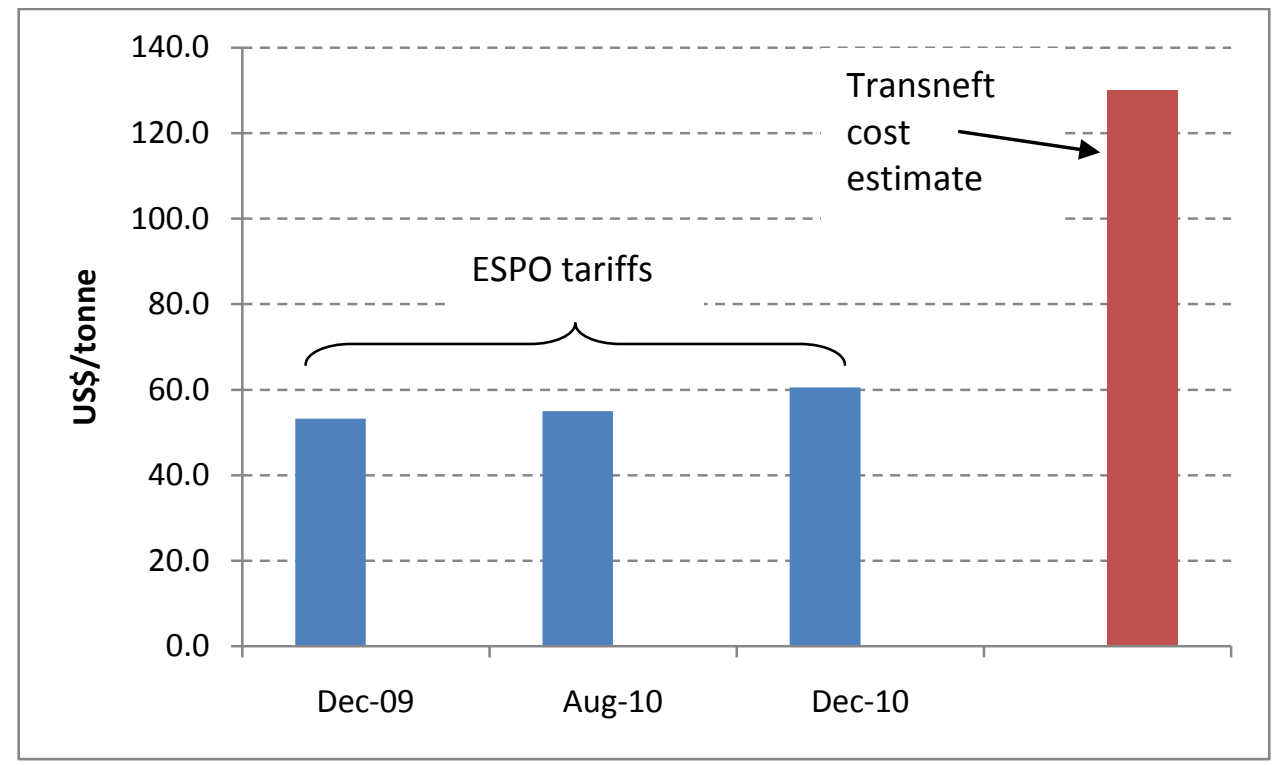

Source: Interfax

However, despite the significance of geo-political relations and transport infrastructure as necessary conditions for the development of East Siberian oil, the most "important step to encourage Greenfield development in the region [has been that] the government approved tax concessions for East Siberian oil and gas projects" (TNK-BP, 2008). These concessions are essentially focused on two major taxes on the oil industry, Mineral Extraction Tax (MET) and Export Tax, both of which have a significant impact on the economics of oil production in Russia. As can be seen from Table 1, MET has an impact on the economics of all oil produced in the country, whether it is sold domestically or overseas, whereas the Export Tax only impacts the $35-40 \%$ of Russian oil that is sold outside the country. Its impact is much higher than MET on the crude sales it affects, but MET has a much broader impact over $100 \%$ of Russian production.

\footnotetext{
${ }^{16}$ Interfax Russia and CIS Oil \& Gas Weekly, 24 Dec 2009, "Regulator approves ESPO network tariff at 1,598 roubles per tonne", Moscow
} 
Table 1: The economics of oil production in Russia

\begin{tabular}{|c|c|c|c|}
\hline \multicolumn{4}{|c|}{ Economics of Russian Oil Production } \\
\hline US\$/bbl & $\begin{array}{c}\text { Export } \\
40 \%\end{array}$ & $\begin{array}{c}\text { Domestic } \\
60 \%\end{array}$ & Average \\
\hline Revenues & 80 & 40 & 56 \\
\hline Export Tax & 39.75 & 0.00 & 15.90 \\
\hline Net Revenues & 40.25 & 40.00 & 40.10 \\
\hline Average opex (inc. expl) & 4.46 & 4.46 & 4.46 \\
\hline Average DD\&A & 3.39 & 3.39 & 3.39 \\
\hline Transport & 6.57 & 3.29 & 4.60 \\
\hline MET & 14.24 & 14.24 & 14.24 \\
\hline Other Costs & 0.80 & 0.40 & 0.56 \\
\hline Pre-tax Profits & 10.79 & 14.23 & 12.86 \\
\hline Corporate Tax & 2.16 & 2.85 & 2.57 \\
\hline Net Income & 8.64 & 11.38 & 10.28 \\
\hline Total Tax Take & 56.94 & 17.48 & 33.27 \\
\hline Tax as \% of Revenues & $71 \%$ & $\mathbf{4 4 \%}$ & $59 \%$ \\
\hline
\end{tabular}

Source: Author's calculations based on Company Data and RF Ministry of Energy data

As can be seen from Table 1, the Export Tax accounts for around 50\% of total export revenues and $70 \%$ of the tax burden on an exported barrel (at an $\$ 80 /$ barrel export price), but in an environment when only $40 \%$ of production is actually sold overseas its impact on an average barrel is reduced to $28 \%$ of total revenues and less than half the total tax burden. The domestic sales are only affected by MET and corporation tax (plus some minor "other" taxes), with MET accounting for over $80 \%$ of the domestic tax burden.

However, the key issue for East Siberia is that the split of its oil sales will not be the same as the average Russian barrel, because domestic demand from a small regional population is relatively low and export sales will therefore contribute a much higher, and growing, proportion of sales as the capacity of the ESPO expands. Oil demand data for East Siberia are difficult to obtain, but one proxy that can be used is the throughput of the four main refineries in the region, Achinsk, Angarsk, Komsomolsk and Khabarovsk. As can be seen in Figure 11, the combined throughput of these plants in 2009 was approximately $550 \mathrm{kbpd}$, while their total combined throughput capacity (and therefore potential future demand) is around 100 kbpd more. When this is put in the context of likely export sales, the capacity of the pipeline to China alone (30 mmtpa) will match domestic demand at $600 \mathrm{kbpd}$, while any extra sales 
via Kozmino Bay, where current loading capacity is $300 \mathrm{kbpd}$, will take the share of export sales well in excess of $65 \%$. Indeed when the ESPO reaches its full capacity of $1.6 \mathrm{mmbpd}$ Transneft foresees a split of domestic and export sales of approximately 600-700 kbpd for internal use and 900-1000 kbpd for exports (Platts, 2010), implying an approximate 60\% export share via the pipe with the potential for further exports to China via the existing rail route.

\section{Figure 11: East Siberia refineries' 2009 throughput and total capacity}

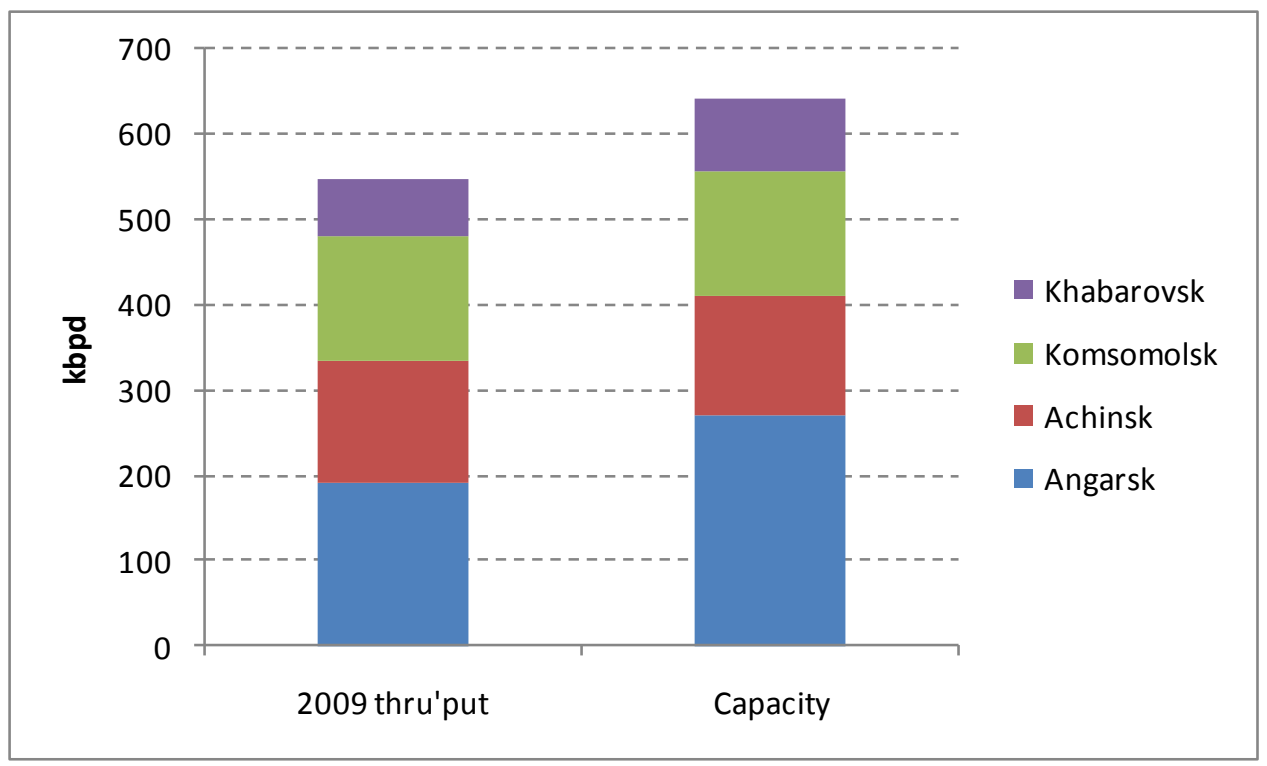

Source: Company Data, Renaissance Capital Oil \& Gas Yearbook 2010

As a result the introduction of a tax exemption covering MET on East Siberian oilfields in $2007,{ }^{17}$ which was the Russian Administration's first attempt to provide a tax incentive for East Siberian oil development, was helpful and in an era of high oil prices was enough to catalyse investment in three major fields, Vankor, Verkhnechonskoye and Talakanskoye, which came onstream in 2008 and 2009. However, when oil prices fell from their high of $\$ 147$ per barrel in 2008 to a low of below $\$ 40$ per barrel in early 2009 the Russian oil companies dramatically reduced spending on all fields that were not close to first production, thus curtailing the medium to long-term growth prospects for the East Siberian and Far East regions. As a result the Russian Administration introduced a series of changes to the export tax charged on East Siberian fields which has had a much more dramatic effect on the economics of oil production in the region.

\footnotetext{
${ }^{17}$ New fields in the region are exempt from MET for 10 years or the first $25 \mathrm{~mm}$ tonnes of production.
} 
On 1 December 2009 a temporary export tax holiday was introduced for exports from East Siberia, with a list of 13 fields approved to receive this new exemption. This list was then extended to a further nine fields on 19 January 2010 (see Table 3), although the total number of 22 fields is somewhat theoretical as only four of them are actually producing and generating export revenues. Furthermore no timeline was given for the tax holiday and once introduced it was essentially re-confirmed on an ad hoc basis, generally once a month, leading to the call noted above for a more consistent and long-term set of rules that could be used as a basis for investment decisions. ${ }^{18}$

An additional complaint about the effective zero tax regime came from the Ministry of Finance, which objected that too much revenue was being given back to the oil industry at a time when Russia as a whole was financially constrained as a result of the 2008/09 crisis. $^{19}$ Indeed the Ministry believed that a continuation of the zero export tax rate for East Siberia would cost the budget 150 billion roubles ( $\$ 5$ billion) in 2010 as a whole, and as a result an adjustment was made in June 2010 to re-introduce a marginal 45\% export tax rate at an oil price above $\$ 50$ per barrel.

Figure 12 shows the impact of the various changes in the tax regime on export sales from East Siberian fields over the past few years. The first column clearly demonstrates that under the general oil industry scheme of full export tax and MET East Siberian fields hardly breakeven at an export price of $\$ 80$ per barrel, meaning that during the lows seen in 2009 significant losses were being made. Column 2 shows the impact of the reduction in MET to a zero rate, while column 3 shows the dramatic change with a zero export tax rate also added. At an export price of $\$ 40$ per barrel this removal of both taxes clearly allows a reasonable profit to be made, but at a price of $\$ 80$ per barrel the Russian Ministry of Finance has strong grounds to raise concerns about excessive profits being generated, with a net margin of $58 \%$ and a profit per barrel of $\$ 47$ per barrel. Even the current tax regime, with the re-introduction of a $45 \%$ export tax at $\$ 50$ per barrel, offers a generous return to oil producers in the region, although the oil companies argue that this return is needed in order to justify investment in new fields. However, even this new regime is somewhat temporary and flexible, as the discounted rates only apply until a $15 \%$ rate of return has been achieved at a field. This is due to occur at various producing fields in the region between 2011 and 2013, but already Rosneft, the field operator at Vankor, has opened negotiations to extend the tax break as far

\footnotetext{
${ }^{18}$ Renaissance Capital Morning Monitor, 15 Feb 2010, "East Siberia zero crude export tax regime still in limbo", A. Burgansky, Moscow

${ }^{19}$ Interfax Russia and CIS Oil \& Gas Weekly, 16 June 2010, “New tax treatment for East Siberian oil to add $353.2 \mathrm{bn}$ roubles in revenue", Moscow
} 
as 2015. Company chairman and Deputy Prime Minister Igor Sechin has announced that the incentives will remain in place until May 1, 2011, ${ }^{20}$ but further negotiations could also then be tied into the ongoing debate about general oil sector taxation that aims to reduce the impact of export tax and MET but to introduce a new excess profits tax. ${ }^{21}$ As a result, although the Russian State has clearly provided a significant short-term tax incentive to the oil industry in East Siberia, the lack of longer-term certainty remains a disincentive to investment in large new fields with high capital expenditure profiles.

\section{Figure 12: Impact of recent tax changes on economics of East Siberia oil exports}

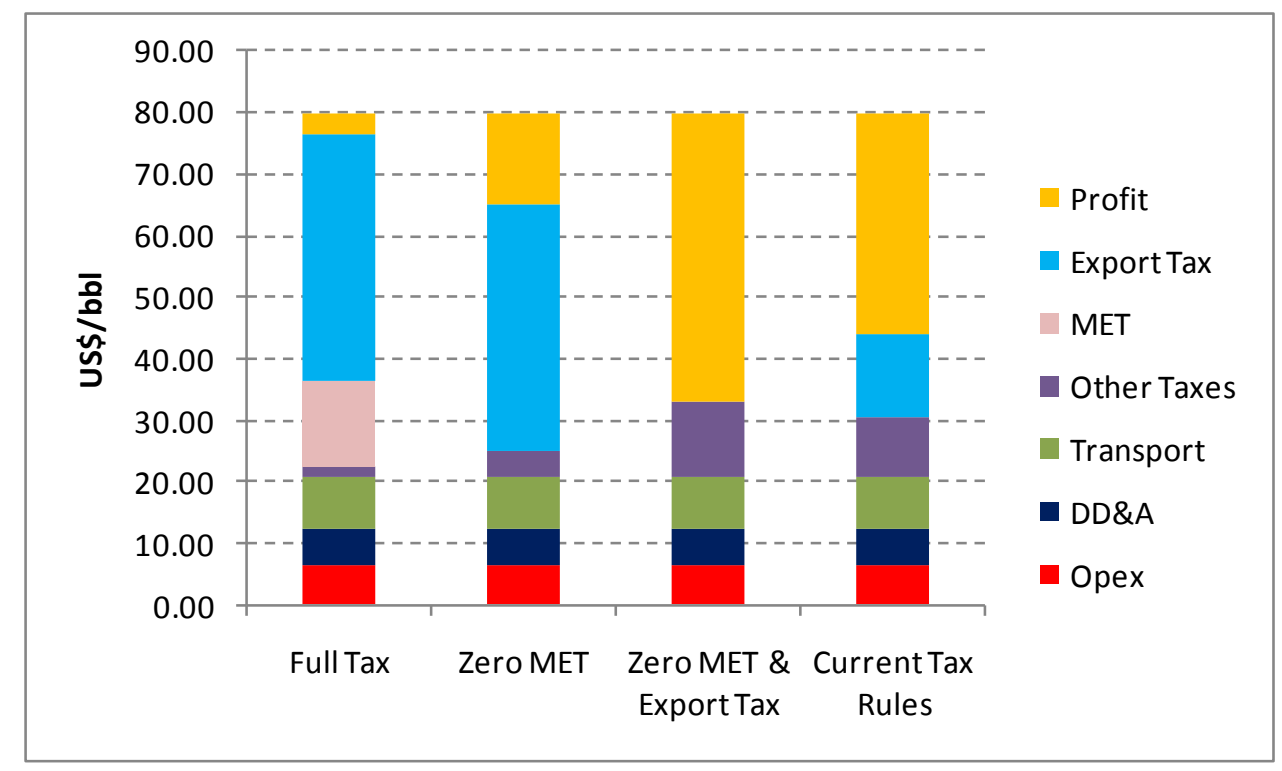

Source: Author's estimates based on Company Data and Data from RF Ministry of Energy

\section{The Resources of East Siberia}

Resource estimates for East Siberia and the Far East vary widely, although most commentators agree that the region accounts for approximately $13 \%$ of Russia's total hydrocarbon reserves. Minina (2007) cites a recoverable reserve estimate for East Siberia alone of 8 billion tonnes of oil plus 1.5 billion tonnes of condensate (for a total of 71 billion barrels of liquids) while other analysts cite a total figure as high as 20-22 billion tonnes (147-161 billion barrels) for East Siberia and the Far East (Poussenkova N., 2007, p. 13). These figures must of course be treated with caution, not least because Russia's eastern regions have only been lightly explored, with an average well drilling density of 2 metres per square kilometre compared with a Russian average density of 23 metres per sq. km

\footnotetext{
${ }^{20}$ Interfax Russia and CIS Oil \& Gas Weekly, 12 Nov 2010, “Discount export duty on Vankor oil to be maintained due to lower production", Moscow

${ }^{21}$ Interfax Russia and CIS Oil \& Gas Weekly, 29 Oct 2010, "Oil sector taxation to 2020: excess profit tax, NRET, export duty - Shmatko", Moscow
} 
(Poussenkova N. , 2008). Furthermore much of the identified resource was discovered in the Soviet era and is located in the Arctic regions, and as a result is unlikely to be commercially recoverable in the near term. Nevertheless, the resource potential is clearly very large, and only a fraction of it would need to be turned into proved reserves to make the region a very important part of Russia and Asia's energy future.

An alternative method of identifying the minimum reserve potential in the region is to sum the company estimates for their main assets located in Eastern Russia. Table 2 contains the data for seven known fields in East Siberia and the Far East, and although the estimates are not exactly comparable they approximate to an estimate of proved and probable reserves for existing assets in the region of just under 10 billion barrels.

Table 2: Reserve estimates for East Siberia and the Far East of Russia

\begin{tabular}{|l|cl|}
\hline & mm bbls & Source \\
\hline Regional Estimates & & \\
Total East Siberia & 71000 & Russian Academy of Sciences (Minina 2007) \\
Total East Siberia and Far East & 161000 & Russian Academy of Sciences (Poussenkova 2007) \\
Field Estimates & & \\
Vankor & 2854 & P\&P oil reserves from Rosneft \\
Verkhnechonskoye & 1323 & P\&P oil reserves from Rosneft \\
Talakanskoye & 909 & C1+C2 oil reserves (Minina, 2007) \\
Yurubcheno-Takhomskoye & 754 & P\&P oil reserves from Rosneft \\
Kuyumbinskoye & 1539 & C1+C2 oil reserves (Minina, 2007) \\
Sakhalin 1 & 1080 & P\&P oil reserves from Rosneft \\
Sakhalin 2 & 1246 & Gazprom Estimate \\
Total & 9705 & Approximate Proved \& Probable Reserves \\
\hline
\end{tabular}

Looking forward from these existing assets to future discoveries, the Russian Energy Strategy includes a forecast of expected increases in oil reserves by region (RF Ministry of Energy, 2009) which foresees growth in East Siberia alone of $165 \mathrm{~mm}$ tonnes in Stage 1 (to 2013), $1200 \mathrm{~mm}$ tonnes in Stage 2 (to 2020-22) and a further 1200mm tonnes in Stage 3 (to 2030). This would imply a total increase in reserves over the next 20 years of 19 billion barrels of oil, which when combined with the existing total identified in the field analysis above (but excluding Sakhalin because it is in the Far East region) would yield reserves of 26.5 billion barrels by 2030 , or approximately $37 \%$ of the total estimated potential of the region. Interestingly the Russian Energy Strategy sees this goal of new discoveries being achieved because East Siberia will become the most active region for drilling over the next two decades, overtaking West Siberia by 2015 (see Figure 13). Although this will clearly only be 
achieved if oil companies see an incentive to invest in the region, it nevertheless confirms the Russian state's enthusiasm for the development of oil and gas activity in the East.

\section{Figure 13: Forecasts of drilling activity in Russia}

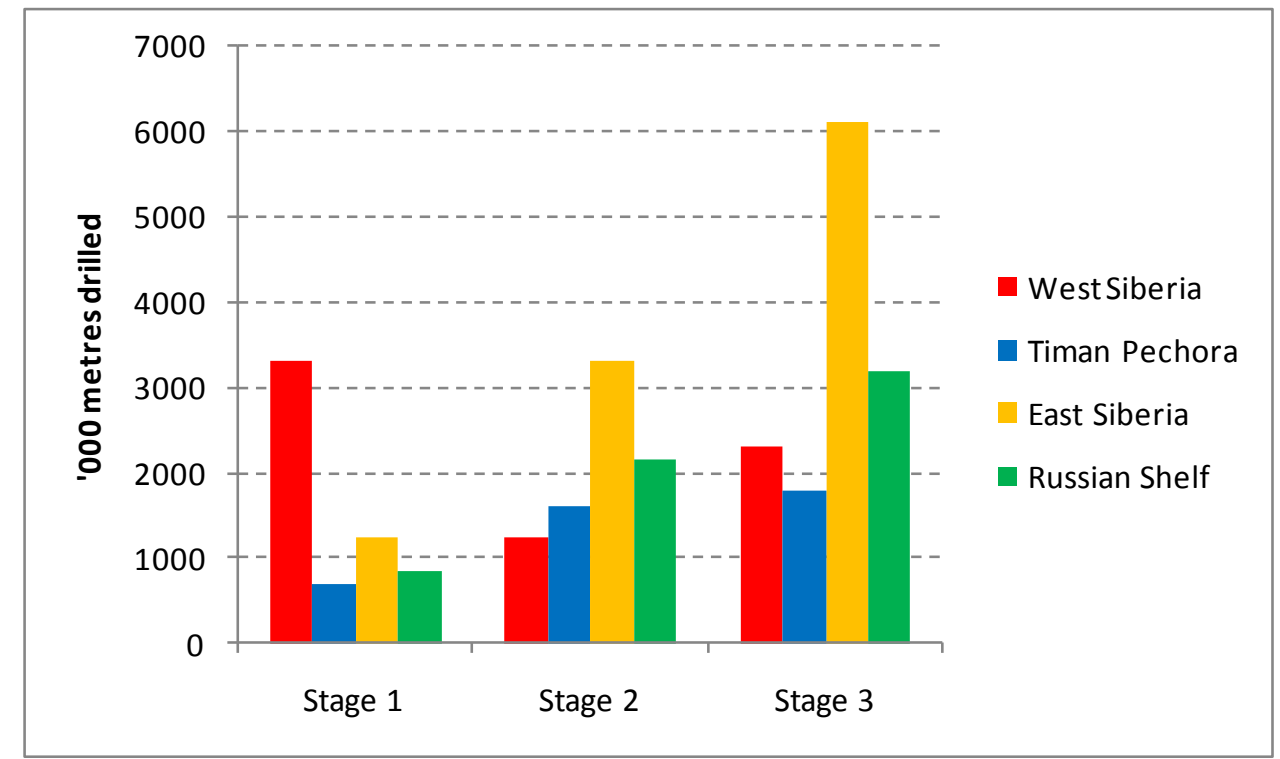

Source: Russian Energy Strategy to 2030 (NB: Stage 1 is up to 2013-2015, Stage 2 is to 2020-22 and Stage 3 is to 2030)

\section{The Activities and Assets of Key Corporate Players in East Siberia and the Far East of Russia}

As has been noted above, the development of Russia's eastern regions has become a national priority, with the energy sector being used as one of the foundations on which to build the development process. As such it is no great surprise that, as Poussenkova $(2008$, p. 14) points out, "the government believes that the monumental task of revitalizing the region and foreign energy ties with Asia can be entrusted only to loyal companies. Therefore, Moscow is creating conditions for displacing private actors in this territory with state-owned corporations and for limiting the role of global actors." As a result, in the gas sector Gazprom has naturally come to dominate, becoming the largest shareholder of the Sakhalin 2 project in the Far East, the leading player in negotiations on gas sales to China, the main developer of gas assets in East Siberia and the new owner of the Kovykta gas field previously controlled by TNK-BP. In the oil sector, however, the situation is slightly more diverse. State-owned Rosneft is certainly the leading player in the region, and is the largest producer of oil, but a number of other Russian and international companies are also active and, as will be described below, could have an important ongoing role given the huge capital investment that will be required over the next 20 years. Indeed it is noteworthy that of the 22 fields on the 
government list for export tax exemptions in the region (see Table 3) only three have Rosneft involvement, with Surgutneftegas, TNK-BP and Irkutsk Oil being the other major players.

Table 3: Fields in East Siberia granted export tax reduction

\begin{tabular}{|cll|lll|}
\hline \multicolumn{2}{|l|}{ Original 13 Fields } & License Holder & & 9 New Fields & License Holder \\
1 & Vankor & Rosneft & 1 & Yaraktinskoye & Irkutsk Oil \\
2 & Yurubcheno-Takhomskoye & Rosneft & 2 & Danilovskoye & Irkutsk Oil \\
3 & Talakanskoye (incl Talakan East) & Surgutneftegas & 3 & Markovskoye & Irkutsk Oil \\
4 & Alinskoye & Surgutneftegas & 4 & Zapadno-Ayanskoye & Irkutsk Oil \\
5 & Srednebotuobinskoye & Sberbank & 5 & Tagulskoye & TNK-BP \\
6 & Dulisminskoye & Sberbank & 6 & Suzunskoye & TNK-BP \\
7 & Verkhnechonskoye & TNK-BP/Rosneft & 7 & Yuzhno-Talakanskoye & Surgutneftegas \\
8 & Kuyumbinskoye & Slavneft & 8 & Vakunaiskoye & GazpromNeft \\
9 & Severo-Talakanskoye & Surgutneftegas & 9 & Chayandinskoye & Gazprom \\
10 & Vostochno-Alinskoye & Surgutneftegas & & & \\
11 & Pilyudinskoye & Surgutneftegas & & & \\
12 & Stanakhskoye & Surgutneftegas & & & \\
13 & Verkhnepeleduiskoye & Surgutneftegas & & & \\
\hline
\end{tabular}

Source: Interfax, 19 November 2009, "Number of East Siberian fields exempt from export duty may rise to 22”, Moscow

\subsection{Rosneft}

The strategic importance of implementing "an urgent, efficient program of economic development for East Siberia and the Far East", as recognised by Vladimir Putin during his presidency (Poussenkova N., 2007, p. 12), has meant that the state-owned companies have been given significant responsibility for the development of energy resources there. In 2002 Gazprom was appointed by the Russian government as the co-ordinator for implementing the state's eastern gas policy with instructions to create a "program for creating in East Siberia and the Far East a single system of gas production, transportation and supplies with due account for possible gas exports to China and other Asia-Pacific countries". In an oil context Rosneft, as the state-owned National Oil Company, has also taken on the role of catalyst for industry development, and indeed East Siberia and the Far East have now become a core part of the company's growth strategy. In its 2009 Annual Report the company recognised that "growth of output in the short and medium term will be determined mainly by fields in East Siberia" and that "long-term production growth by Rosneft will depend on projects in East Siberia and the Far East" (Rosneft, 2010, p. 38), and the extent of the company's reliance on the East for its growth in both the upstream and downstream sectors is becoming ever more obvious.

Rosneft's involvement in Eastern Russia initially stemmed from its ownership of subsidiary Sakhalinmorneftegaz, which owns onshore fields on Sakhalin Island and is also the vehicle 
through which Rosneft owns $11.5 \%$ of its $20 \%$ interest in the offshore Sakhalin 1 project. However, as can be seen from Table 4, the company's eastern asset base now extends well beyond Sakhalin Island and accounts for 11\% of Rosneft's total proved oil reserves.

Table 4: Rosneft's Upstream Asset Base in Eastern Russia

\begin{tabular}{|c|c|c|c|c|c|}
\hline Oil reserves & $\begin{array}{l}\text { Proved } \\
\text { mmbbls }\end{array}$ & $\begin{array}{c}\text { Probable } \\
\text { mmbbls }\end{array}$ & $\begin{array}{l}\text { Possible } \\
\text { mmbbls }\end{array}$ & $\begin{array}{c}2 \mathrm{P} \\
\mathrm{mmbbls}\end{array}$ & $\begin{array}{c}3 P \\
\text { mmbbls }\end{array}$ \\
\hline \multicolumn{6}{|l|}{ Far East } \\
\hline SMNG & 132 & 73 & 46 & 205 & 251 \\
\hline Sak 1 (net 20\%) & 38 & 178 & 158 & 216 & 374 \\
\hline Sub-Total & 170 & 251 & 204 & 421 & 625 \\
\hline \multicolumn{6}{|l|}{ East Siberia } \\
\hline Vankor & 1381 & 1473 & 741 & 2854 & 3595 \\
\hline Verkhnechonsk (net 25.9\%) & 200 & 143 & 133 & 343 & 476 \\
\hline East Siberian O\&G Co. & 208 & 546 & 1107 & 754 & 1861 \\
\hline Sub-Total & 1789 & 2162 & 1981 & 3951 & 5932 \\
\hline Total East & 1959 & 2413 & 2185 & 4372 & 6557 \\
\hline East as \% of Total Rosneft & $11 \%$ & $22 \%$ & $26 \%$ & $15 \%$ & $17 \%$ \\
\hline
\end{tabular}

Source: Rosneft company data from www.rosneft.com

The growth potential of the region is emphasised by the fact that Rosneft's eastern oilfields account for $22 \%$ of the company's probable reserves and more than a quarter of its possible reserves, demonstrating the potential upside from further appraisal and development work at existing assets. Beyond the exploitation of current reserves Rosneft also has further significant growth potential in its exploration portfolio. As shown in Figure 14, recent exploration success combined with estimated future resources offer a further possible 11.5 billion barrels of future oil reserves, assuming that a successful drilling campaign is carried out over the next decade. To put this potential into context, this could give Rosneft total eastern oil reserves of 18 billion barrels, equivalent to the company's entire proved oil reserves today.

Rosneft's commitment to the region is also underlined by the level of its downstream investments there, as it owns three refineries and is expanding its retail and marketing activities. Indeed Figure 15 shows that almost half of the company's refining capacity is located in Eastern Russia, and this will be further enhanced if plans to build an additional 400,000 bpd plant on the Pacific Coast at the end of the ESPO are fulfilled. Only one other 
company owns any refining capacity in Eastern Russia (Alliance Oil with the Khabarovsk plant), further underlining Rosneft's dominance in this sector.

\section{Figure 14: Split of Rosneft's reserves and resources in East Siberia and the Far East}

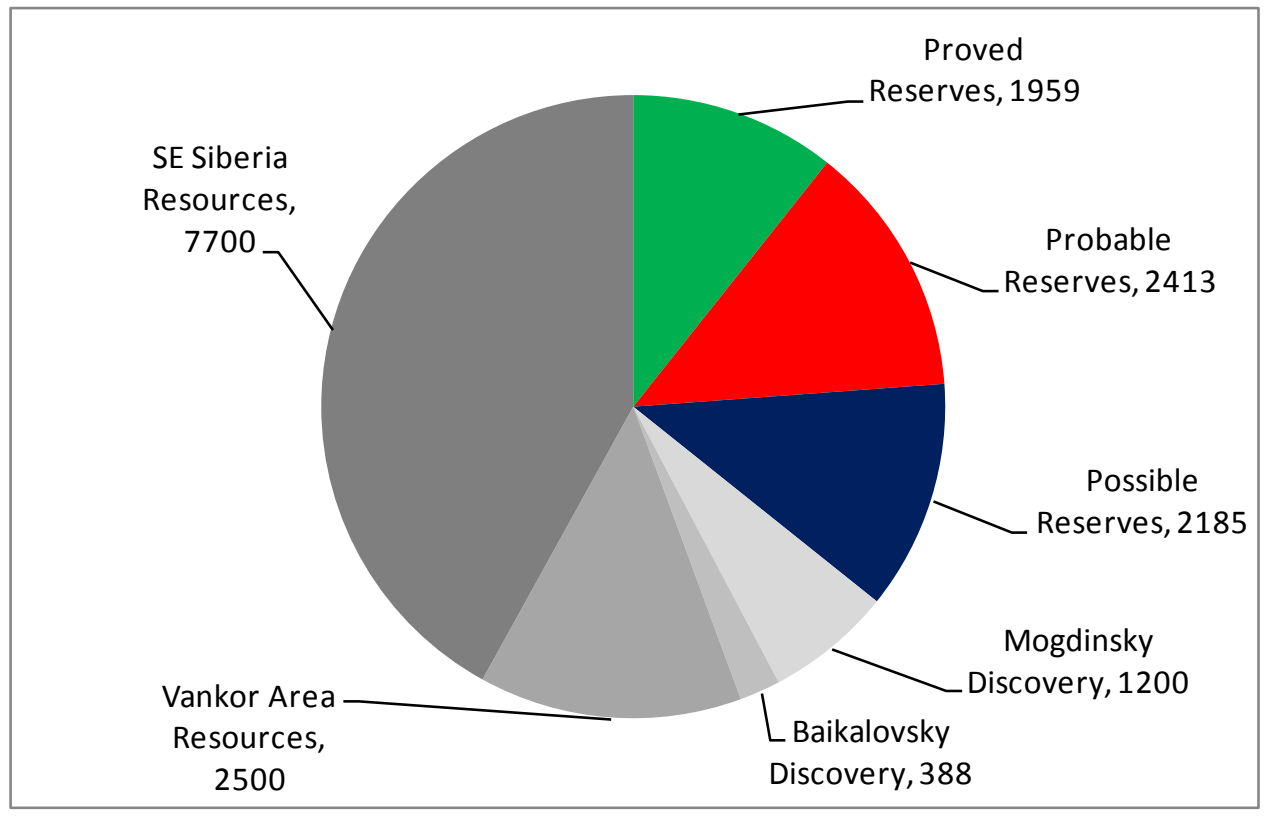

Source: Rosneft company data from www.rosneft.com; all figures are million barrels of oil

\section{Figure 15: Split of Rosneft's Russian refining capacity (mm tonnes per annum)}

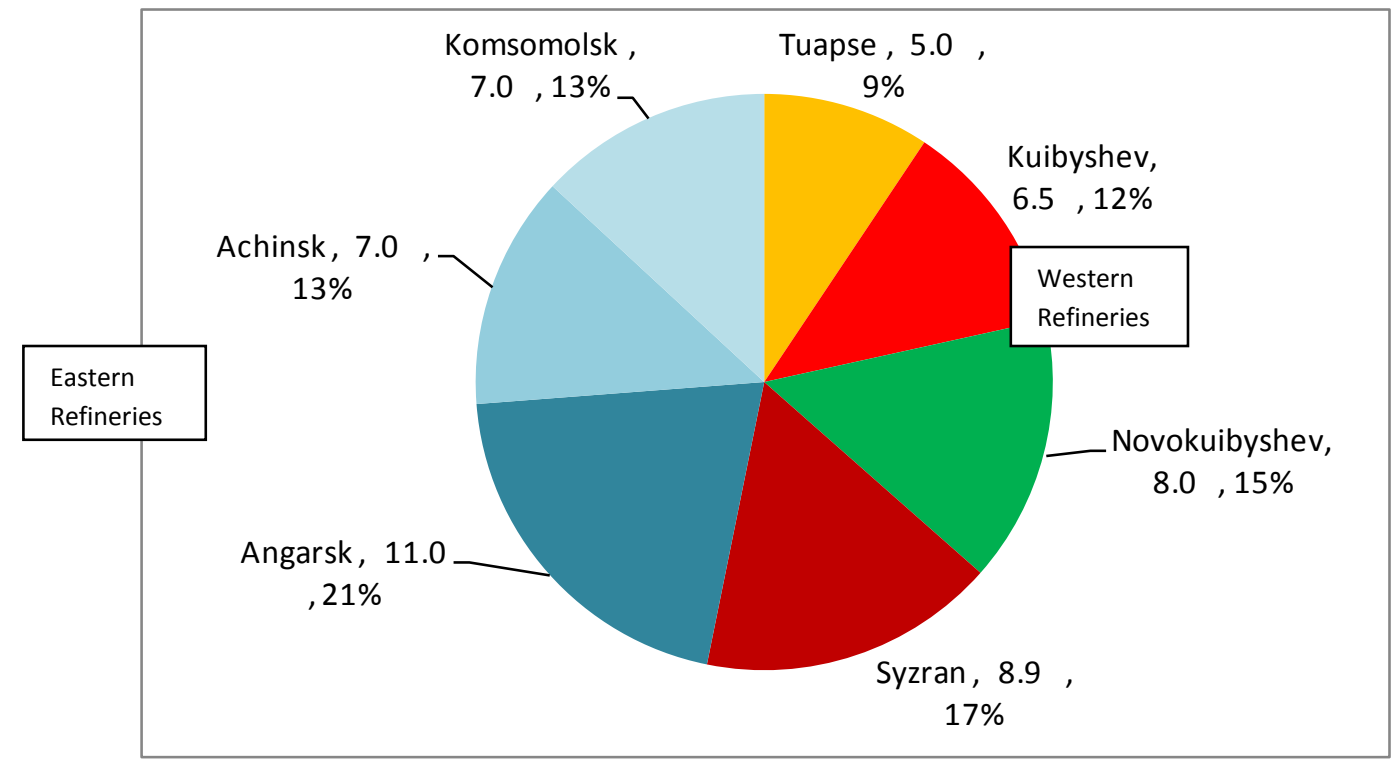

Source: Rosneft company data from $\underline{w w w . r o s n e f t . c o m}$ 
The most important upstream development to date in Eastern Russia, and indeed the largest field brought onstream in Russia in the past 25 years (Rosneft, 2010, p. 16), is the Vankor field located in the north of the Krasnoyarsk region in East Siberia. As shown in Table 4 above, the field has around 2.9 billion barrels of proven and probable oil reserves, and having come onstream in August 2009 is scheduled to reach peak production of 510,000 bpd by 2014, when it will not only be the foundation for Russia's eastern oil exports via the ESPO but will also be providing approximately $5 \%$ of Russia's total oil output.

Rosneft acquired the licence to Vankor when it purchased Anglo Siberian Oil, a small UKlisted exploration and production company, in 2003. The history of the field's development since then demonstrates not only the difficulties of any upstream investment in East Siberia, but also shows the importance of state support and the desire to see domestic control of assets in the region. In 2001 Sibir Energy, another small London-listed company, attempted to take over Anglo-Siberian but its bid was rejected, ${ }^{22}$ and then in 2002 Total attempted to do a deal with Anglo-Siberian to acquire $52 \%$ of the Vankor field but its attempt to gain access to the field was blocked by legal difficulties that were widely viewed as a direct challenge to foreign ownership of the field. ${ }^{23}$ With the active patronage of then President Putin (Poussenkova N. , 2006) Rosneft took control of Vankor in 2003, and after three years of further exploration and appraisal it began construction work. Putin's support culminated in his opening the field in August 2009, when the importance of the asset as a strategic project was emphasised in his statement that "Vankor is the first and therefore a significant step toward the implementation of a large-scale strategic project of comprehensive development of hydrocarbon fields in the northern part of the Krasnoyarsk territory and the YamalNenets autonomous district. A new Russian oil and gas province should appear here within the next few years. ${ }^{24}$ Furthermore the level of state support was also made clear in Putin's insistence that regulations concerning tax exemptions for Vankor and other fields in East Siberia should be accelerated in order to ensure the commercial resilience of the development plans.

Another important aspect of Rosneft's 100\% control over the Vankor field is that it has allowed the company to demonstrate that a domestic company has been able to apply worldclass technology to solve difficult geological and environmental problems. The climate in the

\footnotetext{
22 Upstream Online, "Sibir offensive quashed", 10 July 2001, retrieved 20 Dec 2010

23 Upstream Online, "Total hits Siberian blockage", $23^{\text {rd }}$ February 2003, retrieved 20 Dec 2010

${ }^{24}$ Interfax Russia and CIS Oil \& Gas Weekly, 1 Sept 2009, "Putin launches Vankor field", Moscow
} 
Vankor area is very extreme, ranging from -60 degrees Celsius in winter to +30 degrees in summer, leading to very variable permafrost structures that require difficult technical solutions. As one example, Rosneft quotes "unique thermal soil stabilisation technologies" being used to manage the permafrost in order to avoid movement in the drilling pads and other surface infrastructure (Rosneft, 2010). Below the surface horizontal drilling has been used extensively to maximise the output from the deeper reservoirs, where the thinness of the oil-bearing layers means that vertical wells would be extremely inefficient. In the shallower layers of the field Rosneft is also having to combat high gravity and low well-bore pressure with the use of submersible pumps in directional wells (Uralsib, 2010). This work is being done in partnership with many international service companies, such as Schlumberger and Halliburton, but the success of the field development, completed in only three years, has provided a significant boost to Russia's oil sector credibility.

One further problem, common to all new fields in East Siberia, has been the lack of existing infrastructure, in particular to transport crude oil to market. As a result Rosneft has had to build its own $578 \mathrm{~km}$ trunk pipeline from the field to the village of Purpe, where it can join the trunk pipeline system run by Transneft (Map 2 below). From there the crude is transported south to Taishet, where it enters the ESPO for export to the East (see Map 1). Indeed, following the field start-up in August 2009, the first Vankor crude was exported via tanker from Kozmino Bay, at the end of the ESPO, on December 28th 2009. The importance of this new infrastructure from the Vankor field is demonstrated in Map 2, where the extent of Rosneft's other licences in the Vankor area is clear. Having acquired Vankor in 2003, Rosneft began an extensive acreage acquisition programme between 2005 and 2008, purchasing nine new licences largely through regional auctions and carrying out extensive seismic and exploration work on them. As a result independent reserve auditor DeGolyer \& MacNaughton now estimates that 2.5 billion barrels of prospective recoverable oil resources lie in these blocks (plus $126 \mathrm{bcm}$ of gas), and a first discovery has been made in the Baikalovsky licence which is estimated to contain 388 million barrels of $\mathrm{C} 1+\mathrm{C} 2$ oil reserves (for reserve classification see Appendix 2). The construction of the new pipeline from Vankor into the main Russian trunk pipeline system therefore not only provides a vital link for Vankor crude to international markets, but also makes the commercial development of other discoveries in the area much more likely. Indeed, as will be discussed below, the development of transport infrastructure in this area could allow not only Rosneft's new discoveries but also many other fields in the Yamal region controlled by other companies to be brought successfully to the eastern markets. 


\section{Map 2: Vankor field location with surrounding Rosneft licences}

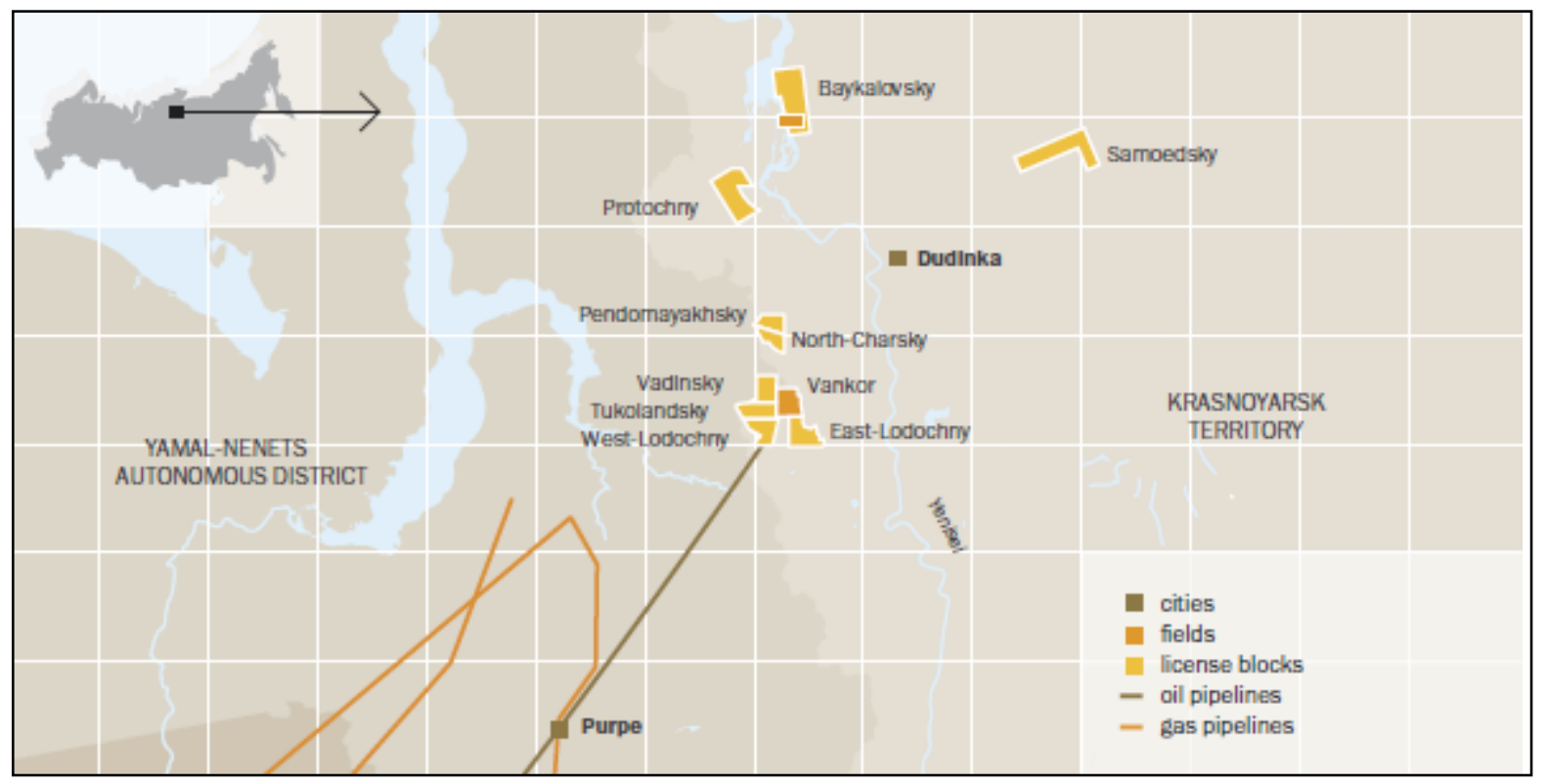

Source: Rosneft Annual Report 2009, page 49

\section{Rosneft's other East Siberian and Far East assets}

Although the Vankor field is Rosneft's largest East Siberian asset in terms of production and proved reserves, the company has built a large portfolio of other fields and licences across the region, in particular in the South of East Siberia. Map 3 shows the extent of the licences that the company has acquired, stretching from the Yurubcheno-Tokhomskoye field in the west of the area to the Verkhnechonskoye field in the east, with all the licences being relatively close to the ESPO pipeline system.

Rosneft gained access to the Yurubcheno-Tokhomskoye field via the acquisition of the East Siberian Oil \& Gas Company (ESOGC) in 2007. ESOGC had previously been owned by Yukos but was put on sale during the bankruptcy auctions, and Rosneft became the obvious buyer given its other Yukos purchases and its dominance of the East Siberia region. The field itself is, like Vankor, complex both geologically and geographically, with a $600 \mathrm{~km}$ pipeline to the start of the ESPO at Taishet being a primary requirement before any commercial development can begin. ESOGC also owns a gas condensate discovery on the Ageleevsky block closer to the ESPO, which could be tied into any new pipeline, and Rosneft may also look to co-operate with Slavneft in developing new infrastructure, as it also owns licences in the region (see Slavneft analysis for detail). Rosneft has also acquired five new licences close 
enough to Yurubcheno-Tokhomskoye to be tied into any new link to the ESPO, thus creating a second potentially significant production base for the company in the East.

\section{Map 3: Rosneft's portfolio of assets in the South of East Siberia}

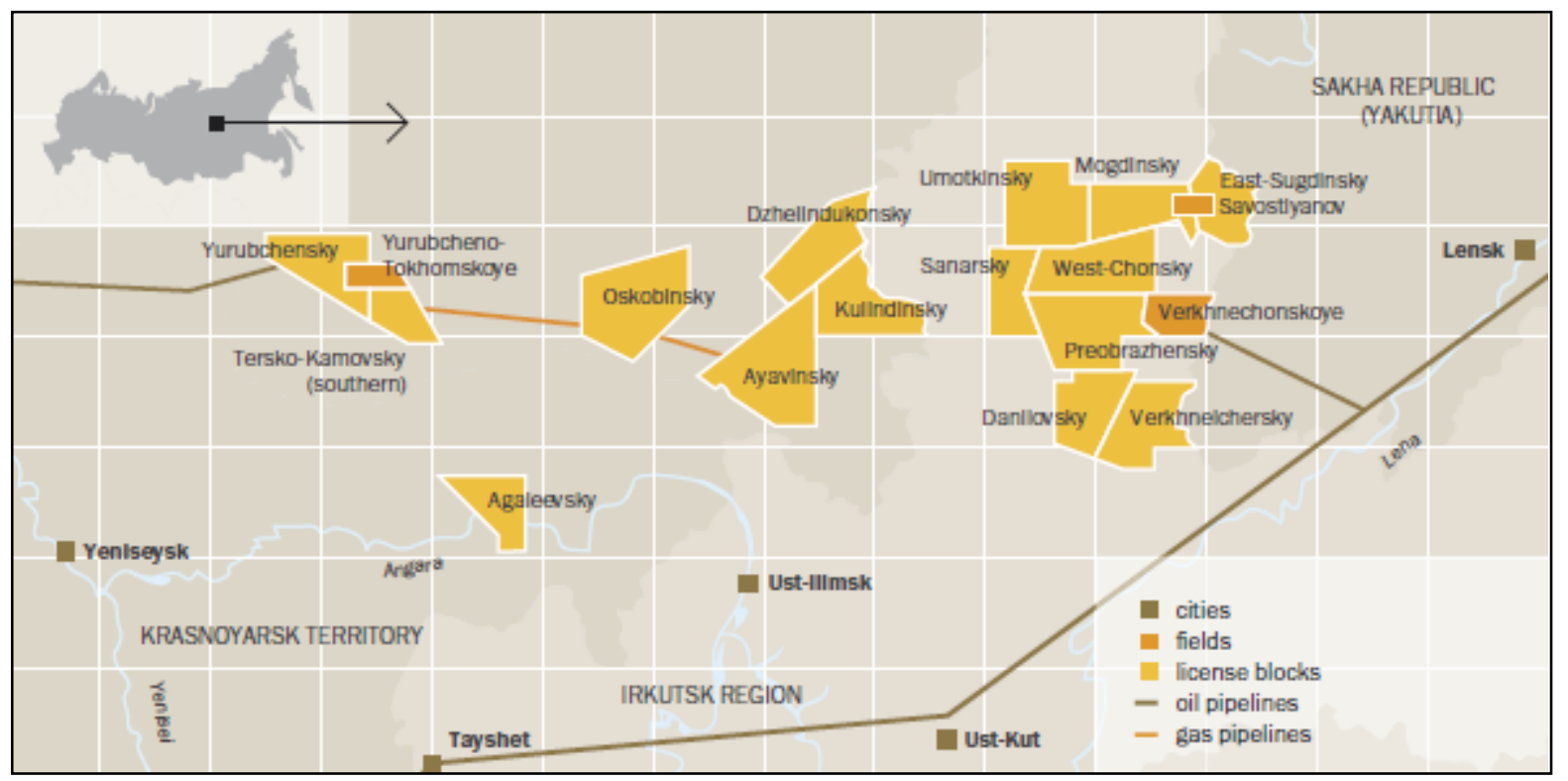

Source: Rosneft Annual Report 2009, page 49

A third core area is being developed around the Verkhnechonskoye field, where Rosneft is a partner with TNK-BP. Although Rosneft only has a $25.9 \%$ interest in Verkhenechonskneftegaz, which operates the main field, it has gradually assumed a dominant position in the region due to further extensive licence acquisitions that have added controlling interests in eight neighbouring blocks to Rosneft's portfolio. A discovery has already been made on the Mogdinsky block, where initial estimates suggest reserves of $1200 \mathrm{~mm}$ barrels at the new Nikolai Savostiyanov field, while a recent assessment of total prospective resources suggests that Rosneft may ultimately discover 7.7 billion barrels of oil plus $800 \mathrm{bcm}$ of gas in its licences in South-East Siberia. As a result, although TNK-BP currently operates the major existing field in the region, with Verkhnechonskoye currently producing 24,000 bpd, Rosneft is likely to become the leading producer in the region and to dominate new infrastructure developments over the next decade.

Rosneft is also using its growing presence in East Siberia to develop deeper relations with its Chinese counterparts, who will receive much of the oil produced in the region. The most important progress to date has been the formation of LLC Vostok Energy, a company owned $51 \%$ by Rosneft and $49 \%$ by CNPC, and the purchase by the company of two of the eight 
blocks neighbouring the Verkhnechonskoye field (Verkhneichersky and West Chonsky). ${ }^{25}$ The two licences were won at auction in July 2007 and extensive seismic was acquired in 2009 prior to a planned drilling programme starting in 2010. No results have been released as yet, but any discoveries would clearly be tied into the existing Verkhnechonskoye infrastructure. Further expansion of Rosneft's co-operation with CNPC was also revealed in December 2010 when Rosneft chairman Igor Sechin announced that Vostok Energy would potentially participate in the development of three blocks off Magadan in the Sea of Okhotsk. ${ }^{26}$ Although no oil resources have yet been identified in the area, the extent of Rosneft's influence as a state company was made clear as the company intended to propose to the licensing authorities that it should be awarded Magadan blocks 1, 2 and 3 on a no-bid basis.

\section{Rosneft represents Russia's oil interests on Sakhalin Island}

In the Far East Rosneft has an even more dominant position as Russia's oil-focused NOC through its interest in projects onshore and offshore Sakhalin Island. Gazprom is Russia's representative there in the gas sector, and does produce some oil from the Sakhalin 2 project, but Rosneft is the domestic company with the longest history in the region and the broadest spread of interests. The company's subsidiary Sakhalinmorneftegaz (SMNG) dominates the onshore developments, and although these are small (approximately $200 \mathrm{~mm}$ barrels of proved and probable reserves) they do contribute 33,000 bpd of production, providing the domestic market with vital supplies via a link to the Komsomolsk refinery, which Rosneft also controls.

SMNG also owns over half of Rosneft's interest in the Sakhalin 1 project. SMNG has an $11.5 \%$ stake in the PSA $^{27}$ with partners ExxonMobil (30\%), Sodeco (30\%) and ONGC (20\%), while Rosneft owns a further $8.5 \%$ via another subsidiary RN-Astra to take its total interest to $20 \% .{ }^{28}$ The project includes three fields, Chaivo, Odoptu and Arkutun-Dagi, which are all located offshore Sakhalin Island and are currently estimated to hold total proved and probable reserves of 1.1 billion barrels of oil plus $285 \mathrm{bcm}$ of gas. Work began on the first

\footnotetext{
${ }^{25}$ Rosneft Management Discussion and Analysis of Financial Condition and Results for Q3 and 9M 2007, p.10

${ }^{26}$ Interfax Russia and CIS Oil \& Gas Weekly, 1 Dec 2010, "Rosneft considering operations in Magadan Shelf", Moscow

${ }^{27}$ Production Sharing Agreement; the legally binding partnership agreement between the field partners and the Russian government, which provides a unique tax and legal framework for the development of a specific oil and gas project. Although PSAs are common for oil and gas projects across the world only three have been signed in Russia, for the Sakhalin 1, Sakhalin 2 and Kharyaga projects.

${ }^{28}$ Data from http://www.sakhalin1.com/Sakhalin/Russia-English/Upstream/about_consortium.aspx, sourced $21^{\text {st }}$ December 2010
} 
stage of Sakhalin-1 in 2004 with the start of full-scale development of the Chaivo field, which came onstream in October 2005 and in 2009 produced 165,000 bpd. Stage 2 then began in May 2009 with first drilling at the Odoptu field, and first production commenced in September $2010 .^{29}$

Stage 3 is more controversial as it involves the development of the extensive gas reserves at the Chaivo field, which the Sakhalin 1 partners are keen to export into the Asian market. However, Gazprom has strongly objected to any scheme that could by-pass its own position as Russia's sole gas exporter, and has insisted that Sakhalin-1 gas be sold to it at domestic market prices. ${ }^{30}$ The dispute is ongoing, with two important implications. The first is clearly that gas sales could be delayed. The second, though, is that this delay could also impact on oil production which is already in decline at Chaivo, and may also make the foreign partners less keen to embark on Stage 4 of the project, the development of the Arkutun-Dagi field which is due to come onstream in 2014. Currently output from the Odoptu field is expected to reach 30,000 bpd in 2011, enough to offset the decline in Chaivo field output, but if the dispute over gas sales continues and the additional debate over total project capital and operating costs, that have been estimated as high as $\$ 100$ billion over the life of the project, ${ }^{31}$ is not resolved with the Energy Ministry, then liquids output could go into short-term decline. Ironically the ongoing dispute could actually benefit Rosneft, as it has been suggested that the Russian Administration may be looking to bring in a domestic operator for the overall Sakhalin 1 project, ${ }^{32}$ an outcome that would mirror the result at Sakhalin-2 where Gazprom took over control from Shell.

Rosneft is not unfamiliar with operating Sakhalin licences as it already controls the Veninsky block on the Sakhalin-3 licence as well as the Sakhalin-5 licence (see Map 4). Sakhalin 3 offers another example of Rosneft's growing partnership links with China, as $25.1 \%$ of the project is still owned by Sinopec (despite reports of exploration work being stopped ${ }^{33}$ ) while Rosneft owns the remaining $74.9 \%$, and the current reserve assessment for the block sees reserves of $34 \mathrm{bcm}$ of gas plus 21 million barrels of condensate under the Russian $\mathrm{C} 1+\mathrm{C} 2$ category. Sakhalin 5, a partnership between Rosneft (51\%) and BP (49\%) is at a slightly

\footnotetext{
${ }^{29}$ Interfax Russia and CIS Oil \& Gas Weekly, 29 Sept 2010, "Exxon puts second Sakhalin-1 field onstream", Moscow

${ }^{30}$ Ibid

${ }^{31}$ Interfax Russia and CIS Oil \& Gas Weekly, 25 Oct 2010, "Exxon Sakhalin-1 costs could hit \$100bn - paper", Moscow

32 Interfax Russia and CIS Oil \& Gas Weekly, 7 Oct 2010, "Russian company could replace Exxon Neftegas as Sakhalin-1 operator - Audit Chamber", Moscow

${ }^{33}$ Bloomberg News, 29 Sept 2010, "Sinopec Group stops exploration at Sakhalin 3", Moscow
} 
more advanced stage of exploration but again the results have been mixed. One of the blocks within the licence (East Schmidt) has been surrendered after disappointing seismic and drilling results. However, the second block (Kaigansko-Vasyukansky) has been retained after a discovery well established initial liquids reserves of 120 million barrels in one of 13 prospects. As a result the licence for the block was extended to 2013, meaning that although hopes of commercial success remain it is clear that Sakhalin-1 will be Rosneft's only offshore producing asset in the region for some time yet.

\section{Map 4: Rosneft's projects offshore Sakhalin Island}

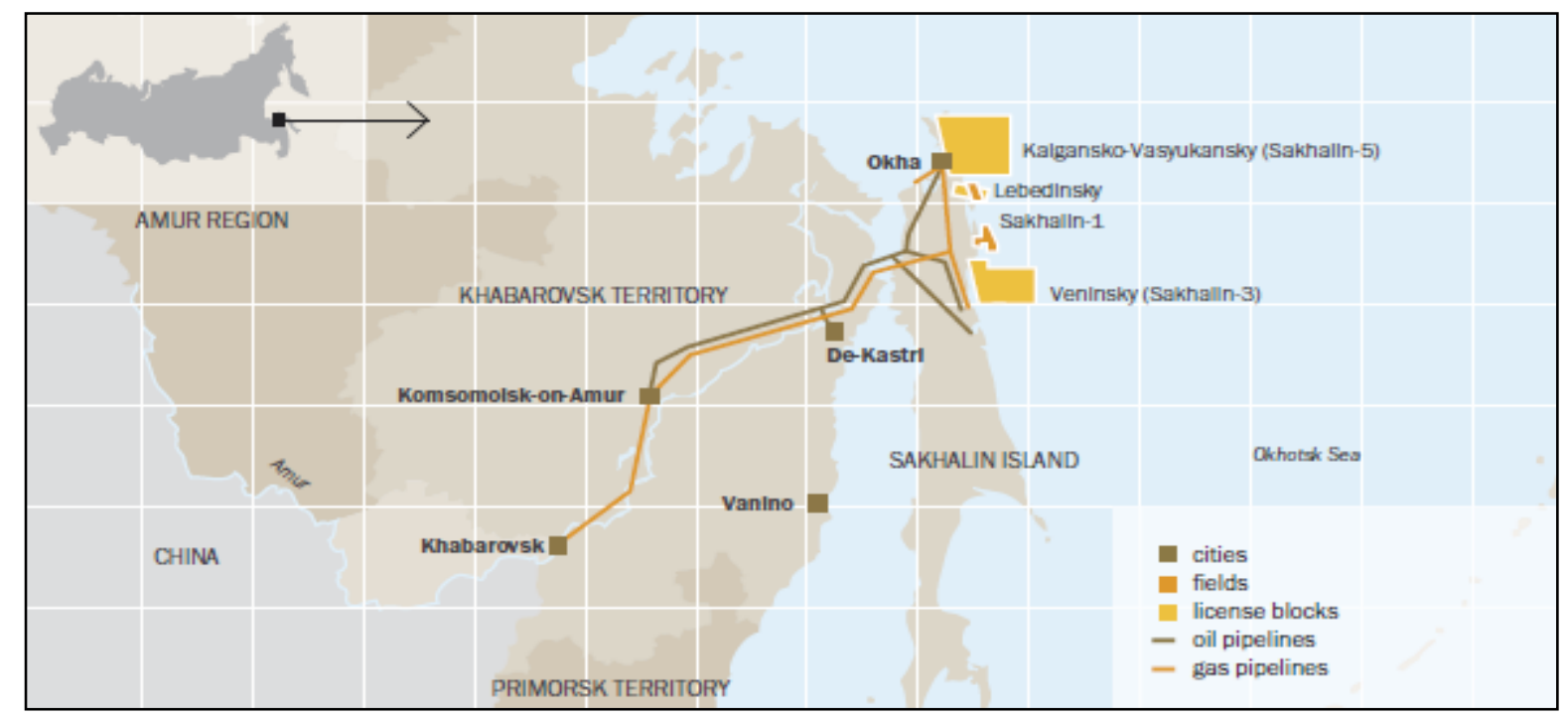

\section{Conclusions on Rosneft in East Siberia and the Far East}

Rosneft is Russia's most important domestic oil company in East Siberia and the Far East, and the region has become an important driver of the company's reserve and production growth over the next two decades. As can be seen from Figure 16 it is likely that Rosneft's production from its existing eastern assets will exceed $700 \mathrm{kbpd}$ by 2017 , and could well be sustained at or slightly above this level with even a moderate amount of exploration and appraisal success. Indeed it is more likely that, given the 1.5 billion barrels of new discoveries already made to supplement the company's 4.4 billion barrels of existing proved and probable reserves in the region, plus a further 10 billion barrels of estimated resources to be explored, output will exceed 1 million barrels per day by 2030 rather than go into any decline.

Rosneft's strategy in East Siberia is being built around three core areas. The Vankor field in the north of the Krasnoyarsk region will be the company's main producing asset in the East 
for the foreseeable future, and a portfolio of exploration licences acquired nearby is likely to provide the extra reserves needed to maintain output once the main field goes into decline. In the south of East Siberia Rosneft is building a further two core areas, one around the Yurubcheno-Takhomskoye field and another around Verkhnechonskoye. The former is more remote from the region's infrastructure, being $600 \mathrm{~km}$ from the ESPO, but Rosneft is likely to co-operate with other companies in the area to build a pipeline into which existing and future discoveries can be linked. The latter field is operated by TNK-BP, but Rosneft has built a significant collection of operated exploration licences nearby and has already made one significant discovery on the Mogdinskaya block. As a result it is likely to become the dominant player in this region too over time, with almost 8 billion barrels of potential resources estimated to exist on its acreage.

In the Far East Rosneft has been a partner at the Sakhalin-1 project since its inception, and the current disputes over gas sales and the budget for future developments could see it become the operator even though it currently has only a $20 \%$ stake. The company already operates at the Sakhalin-3 and Sakhalin-5 licences, although these are both at the exploration stage and have shown limited success to date.

Overall, though, as identified by a number of commentators (including for example Moshkov (2010, pp. 36-48)) Rosneft's East Siberia and Far East assets are likely to be the drivers of any domestic production growth that the company achieves over the next two decades. Indeed the region could be contributing up to $750,000 \mathrm{bpd}$ of oil production, equivalent to one third of the company's total Russian liquids output, by 2020 (see Figure 16). Furthermore Rosneft will also be one of the main actors in Russia's growing energy partnership with China, not only via the crude oil sales agreement that will see the company supplying 300,000 bpd via the ESPO for the next 20 years but also through the Vostok Energy joint venture that has been formed with CNPC. The 2009 loan of $\$ 15$ billion from the China Development Bank to Rosneft ${ }^{34}$ (in addition to the $\$ 10$ billion lent to Transneft) appears to have marked a turning point in Sino-Russian relations, but Rosneft is now broadening the inter-country co-operation beyond the financial sphere to a commercial and operational level.

Furthermore, it is also important to note that Rosneft's growth plans for the region include downstream as well as upstream expansion. Rosneft already owns three plants in the region with 25 mmtpa of refining capacity, and almost $40 \%$ of the company's total oil product exports are now sold to Asian customers (almost $11 \mathrm{mmt}$ of oil products were sold by Rosneft

\footnotetext{
${ }^{34}$ Rosneft press release, 17 Feb 2009, "Rosneft attracted a USD15bn loan from China”, Moscow
} 
into Asia-Pacific markets in 2009). It is now actively considering the construction of a fourth plant to be located in the Primorye region at the end of the ESPO pipeline in order to optimise its potential oil sales to Asia in line with Prime Minister Putin's strategic goal that Russia should add more value to its hydrocarbon exports by selling them as refined products rather

\section{Figure 16: Rosneft's potential production from East Siberia and the Far East to 2030}

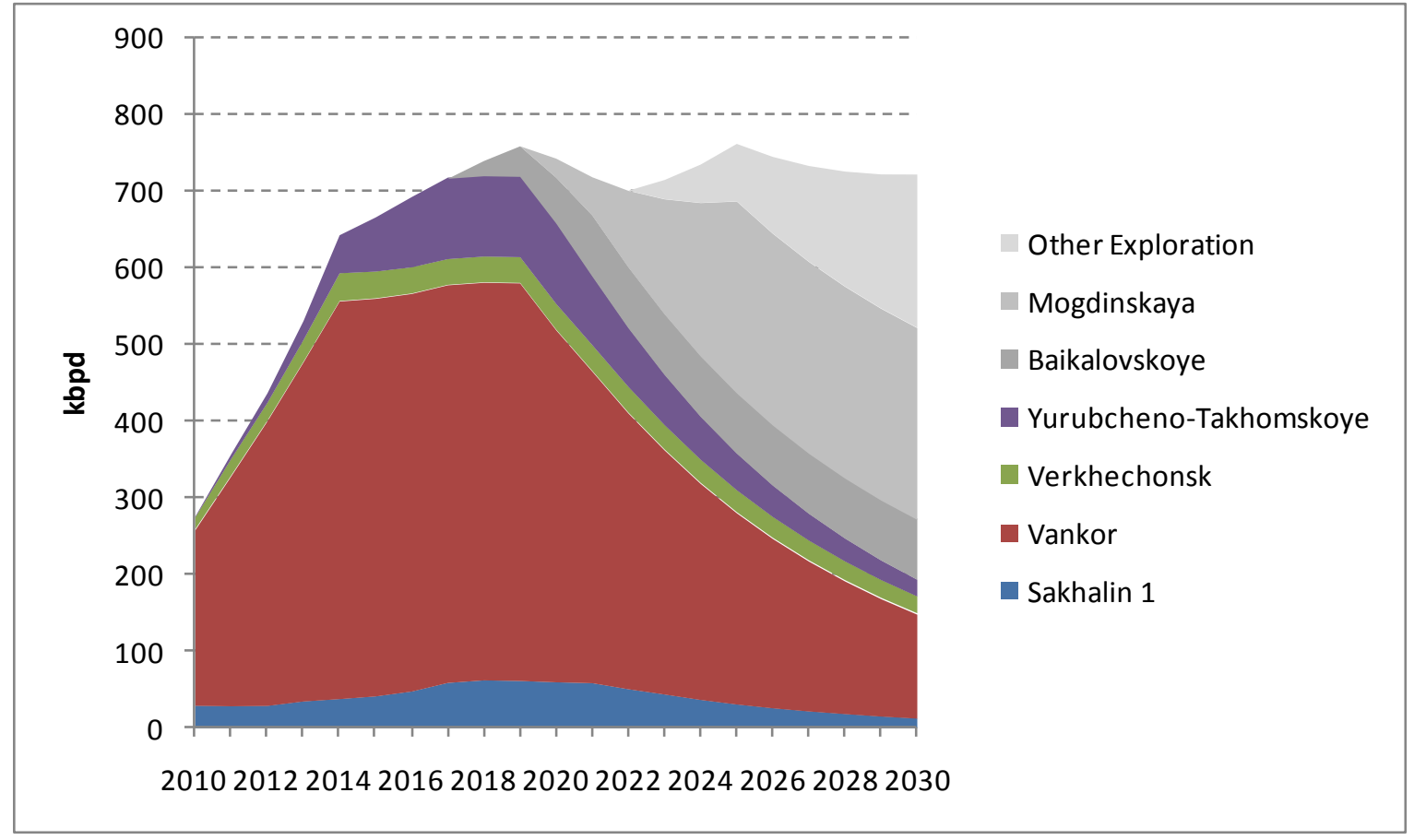

Source: Wood Mackenzie Consultants and Author's Estimates

than crude oil. Plans for the new plant (currently called the Primorye refinery), are at an early stage, $^{35}$ as is reflected in the range of possible size $(10-20 \mathrm{mmtpa})^{36}$ and cost $(\$ 7-14$ billion), ${ }^{37}$ but it seems clear that Rosneft, encouraged by the Russian government, has plans to expand the downstream capacity in eastern Russia and to compete with the existing refineries in the Asia-Pacific region rather than just supply crude oil to them.

Other Key Oil Players in East Siberia and the Far East

\subsection{TNK-BP}

As mentioned above, TNK-BP is the largest shareholder in the Verkhnechonskoye (VKC) field, located in the Irkutsk region of East Siberia, through its subsidiary

\footnotetext{
${ }^{35}$ Interfax Russia \& CIS Oil and Gas News, "Rosneft may decide on building Primorye refinery before year end", 17 May 2010

36 "Japanese firms may invest in Primorye Refinery", Moscow Times, 13 May 2009

37 Interfax Russia \& CIS Oil and Gas News, "Rosneft discussing Primorye refinery with Korean, Japanese firms", 22 Dec 2010
} 
Verkhnechonskneftegaz (VKCNG). Following the recent purchase of a minority $5.48 \%$ stake from a regional company TNK-BP now owns $74 \%$ of VKCNG, with $25.9 \%$ being owned by Rosneft and the remaining $0.1 \%$ held by regional individuals. ${ }^{38}$ TNK-BP and Rosneft have a management agreement in place which allows the two companies to co-operate on field development plans while leaving TNK-BP as the main operator of the field.

The VKC field was discovered in 1978, but a lack of infrastructure combined with the difficult geology of a deep and old field meant that it was left unappraised for 25 years before TNK-BP became involved in 2003 (TNK-BP, 2008). Between 2003 and 2005 a detailed evaluation of the field was carried out which established that the field reservoirs were extremely hard in nature and contained significant salt deposits, with the solution being the drilling of a number of "high angle" rather than vertical wells to maximise oil output. It was further established that of the 4-5 billion barrels of reserves in place approximately 1 billion were recoverable, and the most recent reserves audit has upgraded this figure to 1.3 billion barrels of proved and probable oil reserves (see Table 1 above). Initial exploitation of these reserves began with the implementation of a pilot project in 2005, and confirmation in 2006 of Transneft's plans for the ESPO pipeline led to test production being started in 2007, when 220,000 barrels was produced. The first commercial production was then launched in October 2008 at around $6000 \mathrm{bpd}$, but this increased to 24,000 bpd in 2009.

One of the main commercial advantages of the VKC field is its proximity to the ESPO pipeline, to which the field is connected by an $85 \mathrm{~km}$ spur (see Map 3 above). Initially the two projects had been planned for simultaneous completion at the end of 2008, but a one-year delay in the ESPO deadline led to a potential problem for VKC production. This was resolved by reversing the flow of the ESPO (which had reached VKC by the end of 2008 but did not yet reach Skovorodino) and sending crude from VKC to Rosneft's Angarsk refinery, replacing some of the crude sent by Rosneft from West Siberia. However, now that Stage 1 of the ESPO has been completed any constraint on potential VKC output has been lifted, and production was expected to reach 53,000 bpd in 2010 (see Figure 17) before peaking at 150,000 bpd by 2017 (TNK-BP, 2010, p. 11). Indeed TNK-BP's first tanker of VKC crude left Kozmino Bay at the end of the ESPO line in January $2010,{ }^{39}$ since when it has sold

\footnotetext{
${ }^{38}$ Interfax Russia and CIS Oil \& Gas Weekly, 22 Nov 2010, "TNK-BP to acquire 5.48\% in Verkhnechonsk operator for $1.5 \mathrm{bn}$ roubles", Moscow

${ }^{39}$ Interfax Russia and CIS Oil \& Gas Weekly, 30 Dec 2009, "TNK-BP's first tanker with ESPO oil set to sail Jan 4", Moscow
} 
around two cargoes per month into the Asian market and recently broadened its sales area by concluding its first sale of ESPO crude to Vietnam. ${ }^{40}$

\section{Figure 17: Verkhnechonskoye production profile}

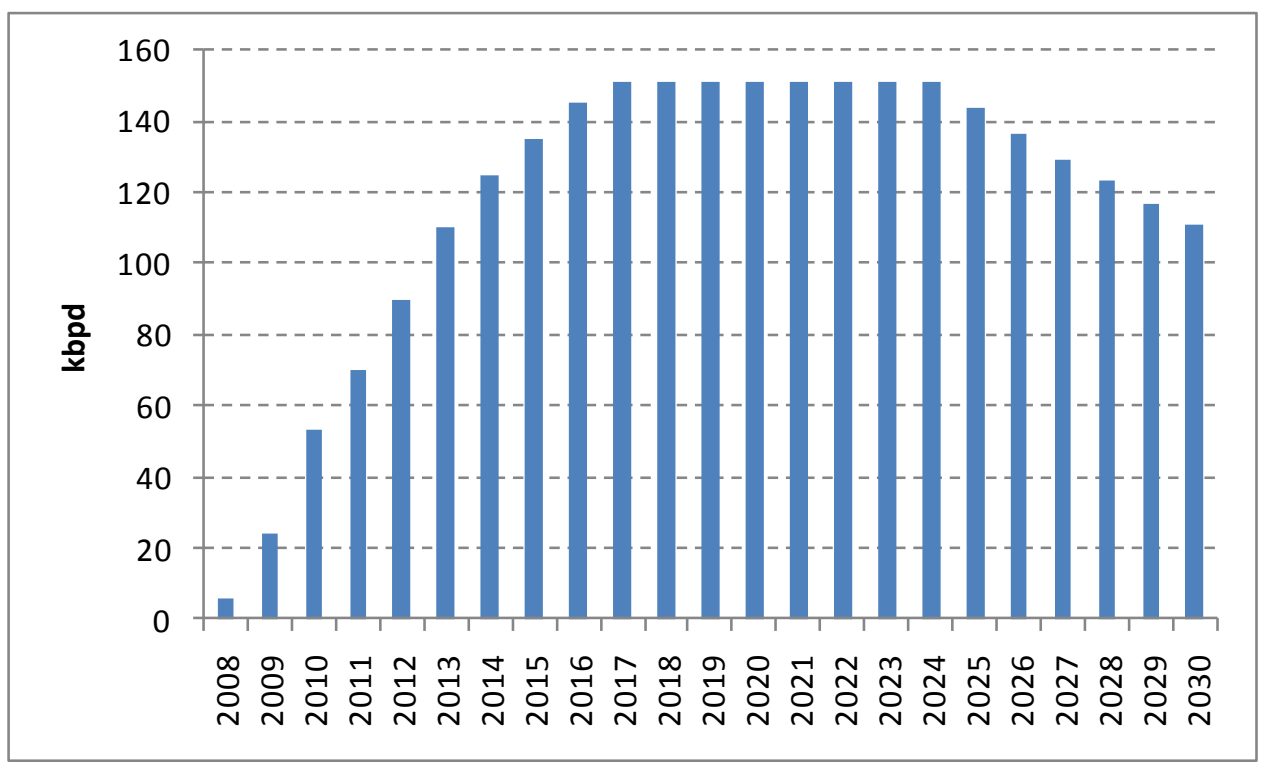

Source: TNK-BP data

Although Verkhnechonskoye is undoubtedly TNK-BP's most important East Siberian asset to date, the company does own two other fields on the list of 22 exempt projects. Interestingly, though, Suzunskoye and Tagulskoye, which are located in the Bolshetetskaya Depression in the northern Krasnoyarsk region, might more accurately be described as West Siberian fields with the potential to provide oil supply to the ESPO pipeline. Their location is directly north of fields such as Zapolyarnoye, which would normally be regarded as West Siberian, but a suggested pipeline link to Purpe could give them the same access to the ESPO as Rosneft's Vankor field.

Suzunskoye and Tagulskoye are both at a relatively early stage of exploration (TNK-BP, 2010, p. 14) but are estimated to contain significant resource potential. Suzunskoye, which is the best explored of the two, is believed to contain $300 \mathrm{~mm}$ barrels of possible reserves and resources, and could come onstream as early as 2015. Tagulskoye, which is a more complicated field with lower quality oil, could contain 1.9 billion barrels of possible reserves and resources, and has a tentative start date of 2016, but the timetable for both fields will be largely subject to the resolution of infrastructure issues, in particular the building of a pipeline to Zapolyarnoye and on to Purpe. As such, although the two fields are included in an

\footnotetext{
${ }^{40}$ Interfax Russia and CIS Oil \& Gas Weekly, 27 Sept 2010, “TNK-BP, PetroVietnam sign ESPO blend oil supply contract", Moscow
} 
estimate of TNK-BP's production potential through the ESPO in Figure 18, the timing of their production remains speculative. Nevertheless their long-term potential is clear, and TNK-BP has a further three discoveries in the same area that have yet to be granted preferential tax status but which could provide further long-term growth.

\section{Conclusions on TNK-BP as an East Siberian oil producer}

TNK-BP's initial interest in East Siberia was focused on the Kovycta gas field, with its potential to supply the Chinese market. However, the stalling of this project by Gazprom and by the ongoing bankruptcy of Rusia Petroleum, the TNK-BP subsidiary that operates the field, ${ }^{41}$ has left the company to focus on its oil potential in the region, which is concentrated in a single field, Verkhnechonskoye. TNK-BP, in partnership with Rosneft, has successfully applied complicated technology to a difficult geological structure and has also exploited the opening of the ESPO to develop a highly commercial field that will be producing 150,000 bpd of oil by 2017. The tax breaks available to East Siberian fields have also been a vital part of the justification for an investment programme that is likely to reach $\$ 4-5$ billion by the time full field construction is completed, and these tax breaks will also be essential for the realisation of TNK-BP's other two "East Siberian" projects, Suzunskoye and Tagulskoye. These fields are effectively in the east of West Siberia, but they have gained tax exempt status because of their potential to fill the ESPO pipeline, although significant infrastructure hurdles need to be overcome before this can be achieved. However, if they can be brought onstream by the middle of this decade then TNK-BP could be producing up to 250,000 bpd through the ESPO and into Asian markets by 2020 (see Figure 18).

\footnotetext{
${ }^{41}$ Interfax Russia \& CIS Oil and Gas News, "Auction of Rusia Petroleum assets pushed back to March 1", 8 Feb 2011
} 


\section{Figure 18: TNK-BP's production potential from East Siberia}

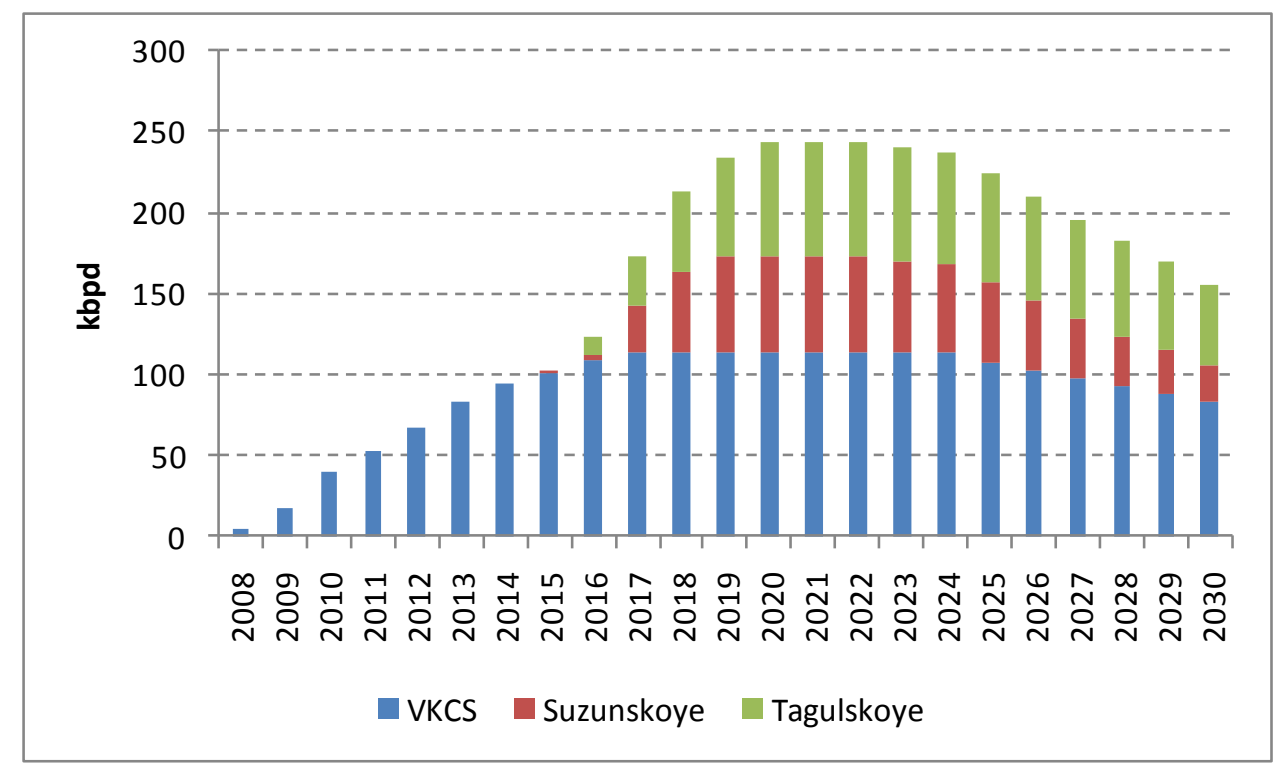

Source: TNK-BP data, Wood Mackenzie Consultants

\subsection{Surgutneftegas}

It is clear from the list of East Siberian fields that have been granted preferential tax status that Surgutneftegas has a broad exposure to the region as eight of the 22 fields are controlled by the company. However, Surgut's traditional reticence about revealing detailed data on its assets means that it is hard to make an accurate assessment of its long-term potential in Eastern Russia. The company itself describes East Siberia as "one of the most promising regions for development of the company's production" (Surgutneftegas, 2010, p. 37) and sees it as a core region for future growth, and it has built one of the largest licence portfolios of any of the domestic companies on which to build its eastern strategy.

Surgut's growth plans are being built around the Talakanskoye field which is located in the Sakha region of East Siberia and is very close to the ESPO pipeline, which actually passes right next to the field at the end of the $1100 \mathrm{~km}$ stretch of the pipe from Taishet to Talakan via Ust-Kut. Work on the Talakanskoye field began as Surgutneftegas first entered East Siberia in 2003, with full construction of well-sites and field infrastructure starting in 2005. Field reserves have been estimated at $124 \mathrm{~mm}$ tonnes of oil (approximately $900 \mathrm{~mm}$ barrels), and these began to be produced in October 2008 when the first section of the ESPO pipeline to Talakan was completed. As with the Verkhnechonskoye field, the first oil flows used the ESPO in reverse, sending oil back to the Angarsk refinery in Irkutsk, but from the end of 2009 oil began to flow east and Surgutneftegas' first cargo from Kozmino Bay was 
despatched in January 2010. Production from the field reached around 60,000 bpd in 2010 and is expected to peak at more than double that rate by 2015, providing a vital support for Surgutneftegas' overall production profile as its West Siberia fields go into decline.

Surgutneftegas has a second producing field in the same region, and in fact the Alinskoye field, which came onstream in mid 2009, is a satellite of Talakanskoye as it is located only 35 $\mathrm{km}$ away. No reserve estimates for the field are available, but some analysts have put the production potential at $10-20,000 \mathrm{bpd}^{42}$ and the company itself has stated that combined output from the two fields (Talakan and Alinskoye) could reach or exceed $7 \mathrm{~mm}$ tonnes per annum $(140,000 \mathrm{bpd}){ }^{43}$

Surgutneftegas then has a further six fields in East Siberia that have been classified as discoveries, and at an investor conference in October 2010 it outlined its plans for a development timetable for them over the next five years. The company plans to launch the Severo-Talakanskoye field in 2012, Vostochno-Alinskoye in 2013, the eastern section of the Talakanskoye field and Yuzhno-Talakanskoye in 2014 and Stanakhskoye and Pilyudinskoye in $2015 .{ }^{44}$ Again, specific data on production volumes and reserves are very limited, but on the assumption that these fields are of a similar scale to Alinskoye then it is possible to estimate total output from these six fields reaching a peak of approximately $60,000 \mathrm{bpd}$ beyond 2020, thus offsetting some of the decline in the Talakanskoye field (see Figure 19 below).

Beyond the eight fields that Surgutneftegas has already discovered in East Siberia, the company has a further 12 licences where the focus is currently on exploration of new prospects. The majority of these are in the Sakha region, but a small number are also located in Irkutsk. The company has been expanding its exploration activities in East Siberia rapidly over the past few years and in 2010, for example, more than $70 \%$ of its $2 \mathrm{D}$ seismic exploration work was scheduled for this region, with the traditional core areas such as West Siberia being significantly downgraded (Surgutneftegas, 2010, p. 39). Drilling is also increasing, with 15 exploration wells drilled in 2009 and a further 17 planned to be completed

\footnotetext{
${ }^{42}$ For example a UBS report of 27 Sept 2010, “Russian Oil \& Gas Sector Review”, pp.72-82

${ }^{43}$ Interfax Russia and CIS Oil \& Gas Weekly, 22 Sept 2010, "Surgutneftegas looks to produce 3 mln tonnes of oil at Talakan in 2010 ", Moscow

${ }^{44}$ Interfax.ru, 11 Oct 2010, "Surgutneftegas plans to double oil output in East Siberia", sourced on 22 Dec 2010
} 
by the end of $2010,{ }^{45}$ while production drilling rose by $32 \%$ in 2009 with the completion of 49 wells, including 19 drilled horizontally.

Although any estimate of the potential impact of this exploration activity must be tentative, it is nevertheless possible to speculate that Surgutneftegas' exploration licences could yield enough success (I assume a further five discoveries similar to Alinskoye) to allow the company to minimise any decline in production after 2020. As a result Figure 19 shows the estimated output from the currently producing Talakanskoye and Alinskoye fields reaching a peak in 2015, but being supplemented by output from the six other fields that Surgutneftegas plans to bring onstream over the next five years. Output from all eight fields could peak at approximately 200,000 bpd by 2020, and then be maintained at between 180-200,000 bpd for the next decade if a reasonable level of exploration success is achieved.

\section{Figure 19: Potential output from Surgutneftegas' East Siberian fields}

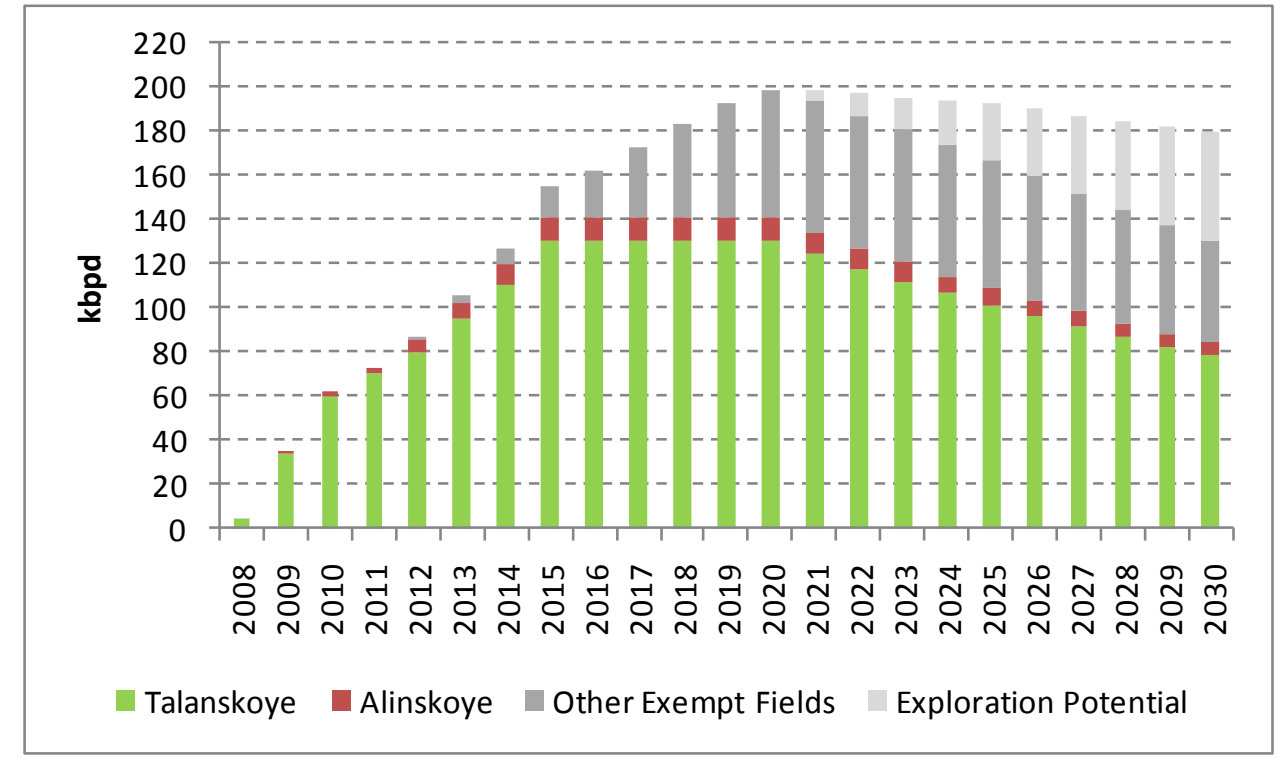

Source: Surgutneftegas data and Author's Estimates

Conclusions on Surgutneftegas in East Siberia

Surgutneftegas has targeted East Siberia as a significant growth area for the company as it seeks to bolster its overall production profile in the face of a declining West Siberian asset base. The company has two currently producing fields on which to base its growth, with Talakanskoye being its core asset in the region. A lack of detailed data means that it is difficult to assess the potential of six new field developments that are planned over the next

\footnotetext{
${ }^{45}$ Interfax Russia and CIS Oil \& Gas Weekly, 26 Oct 2009, "Surgutneftegas plans to boost exploration drilling in Eastern Siberia by $13 \%$ in $2010 "$, Moscow
} 
five years, but it would not seem unreasonable to suggest that Surgutneftegas' total output from East Siberia could reach 200,000 bpd by 2020. The company's extensive exploration portfolio could then be expected to provide enough new assets to at least keep output stable at a similar level, although this is clearly a tentative estimate at this stage. Nevertheless, Surgutneftegas will make a significant contribution to the throughput of the ESPO over the next twenty years and has already sold a number of cargoes into the Asia-Pacific market. ${ }^{46}$

\subsection{Irkutsk Oil}

The smallest company directly involved in producing oil in East Siberia is Irkutsk Oil, which is a privately-owned entity that was formed in 2000 by the Russian entrepreneur Nikolai Buynov. He remains the chairman of the company's board while owning, with the other management of Irkutsk Oil, $91.85 \%$ of the company. The remaining $8.15 \%$ is owned by the EBRD, which purchased its stake in May 2008 for $\$ 85 \mathrm{~mm}$ as part of a deal to provide funds for the company to implement projects to reduce emissions from gas flaring. ${ }^{47}$

Irkutsk remains a local company owning 12 licences in the Irkutsk region, four of which are producing and eight of which are exploration. The company's four producing licences contain fields that were included on the second list of nine assets that have been granted preferential tax status, and output from the Yaraktinskoye, Danilovsky, Markovsky and Ayansky assets is expected to rise sharply over the next five years. However, the company has been reluctant to reveal any definitive data on the reserves which it owns in these fields, probably due to concerns over political views on the strategic nature of such information. Wood Mackenzie Consultants estimates that the gross commercial reserves in Irkutsk's four producing fields total approximately $230 \mathrm{~mm}$ barrels of oil, ${ }^{48}$ although various quotes attributed to the company since 2006 suggest that this figure may be conservative. In September 2006 Irkutsk Oil's current CEO Marina Sedykh stated that the company possessed recoverable reserves under the Russian $\mathrm{C} 1+\mathrm{C} 2$ definition totalling 14.9 million tonnes of liquids plus $70 \mathrm{bcm}$ of gas (110 million barrels of liquids, $530 \mathrm{mmboe}$ of total reserves), ${ }^{49}$ and a further update was provided in September 2008 when it was stated that a further 31 million

\footnotetext{
${ }^{46}$ For example, Bloomberg, July 29 2010, "Surgutneftegas sells East Siberian crude oil cargoes to Mitsui and Vitol", sourced 22 Dec 2010

${ }^{47}$ Interfax Russia and CIS Oil \& Gas Weekly, 26 May 2008, “EBRD invests \$85mm in Irkutsk Oil Company", Moscow

${ }^{48}$ Data from Wood Mackenzie CAT database. Commercial reserves approximate to an estimate of proved and probable reserves under the widely used SPE methodology.

${ }^{49}$ Interfax Russia and CIS Oil \& Gas Weekly, 21 Sept 2006, “Irkutsk Oil Co. Ready to take part in filling ESPO ”, Moscow
} 
tonnes of liquids had been added. ${ }^{50}$ This would imply total $\mathrm{C} 1+\mathrm{C} 2$ reserves of 335 million barrels of liquids plus $70 \mathrm{bcm}$ of gas for a combined total of $755 \mathrm{mmboe}$ of total reserves.

Thanks to the development of this significant resource base Irkutsk Oil has become the fourth largest producer in East Siberia, with oil output totalling 14,000 bpd in 2010 and targeted to reach 25,000 bpd by the end of 2011. Full development of its four producing fields, combined with exploitation of recent exploration successes, could then see further growth towards the company's strategic goal of 75,000 bpd of output by $2015,{ }^{51}$ and potentially to $80,000 \mathrm{bpd}$ beyond that date (see Figure 20). The company's oil, which has a lower sulphur content and is of higher quality than the traditional Russian Urals Blend, has been transported by rail to Nakhodka on the east coast of Russia during 2010, but a further important strategic development for the company will be the completion of a connection with the ESPO pipeline. The link from the Yaraktinskoye field only stretches $61 \mathrm{~km}$, emphasising the proximity of Irkutsk's assets to this important pipeline link, and is expected to be completed in January 2011 with an initial capacity of $30,000 \mathrm{bpd}$ rising to 70,000 bpd as expansion projects are introduced to match the increase in overall company output. Irkutsk Oil will then have much easier and cheaper access not only to the Chinese market but also to Japan, where it has been building important strategic links.

Figure 20: Irkutsk Oil production forecast

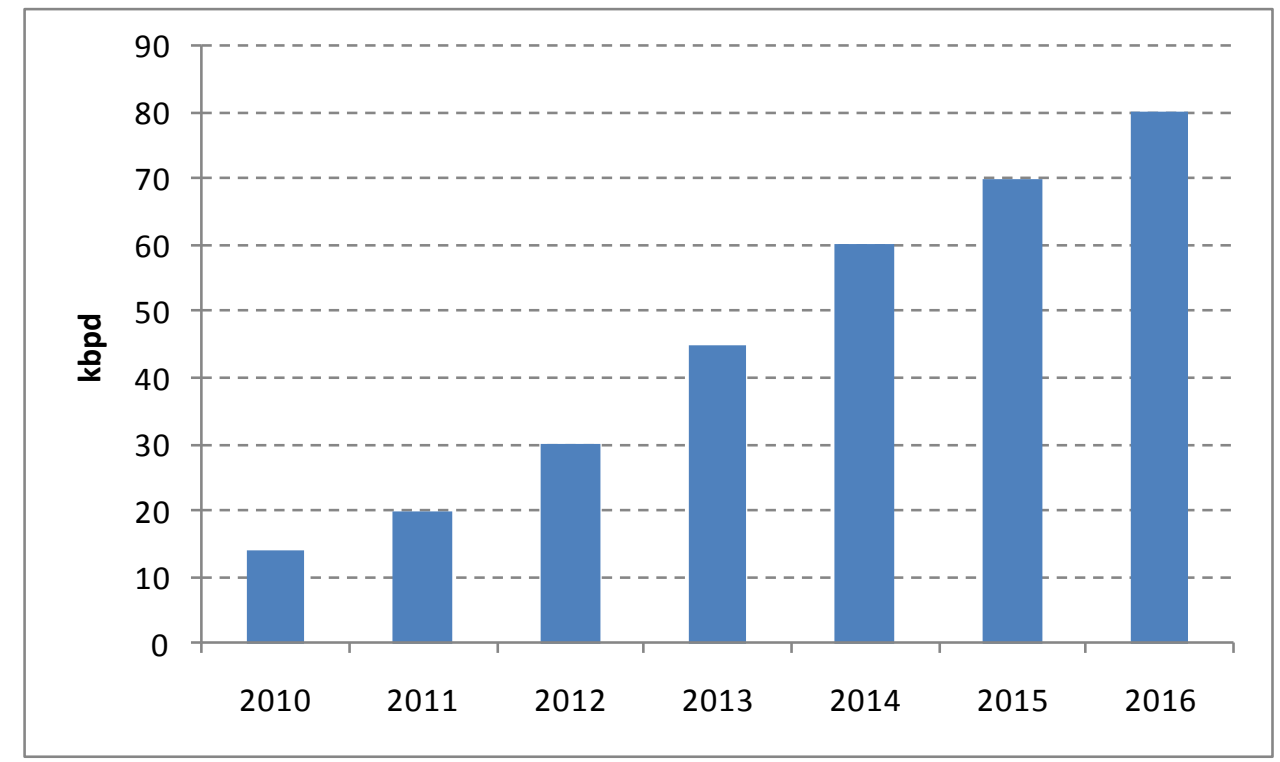

Source: Company data and Author's estimate

\footnotetext{
${ }^{50}$ Interfax Russia and CIS Oil \& Gas Weekly, 11 Sept 2008, “Irkutsk Oil may double input to ESPO”, Moscow ${ }^{51}$ Data from Irkutsk Oil web-site at http://www.irkutskoil.com/section 49/section 62, accessed on Jan $3^{\text {rd }}$ 2011
} 
The importance of the company's growing links with Japan as a source of future growth was emphasised in October 2010 when Irkutsk Oil announced that it had made three new exploration discoveries on licences that it owns via a joint venture with JOGMEC, the 100\% state-owned Japanese oil company. In establishing this JV (in 2007) ${ }^{52}$ with an Asian company Irkutsk has essentially followed the example set by Rosneft in seeking to both explore and produce oil in partnership with a company that can also help to find a secure market outlet for any production. The joint venture is owned $51 \%$ by Irkutsk Oil and $49 \%$ by JOGMEC, and has now made two oil and one gas discovery on its acreage. The most significant find is on the Severo-Mogdinsky block, where two successful wells have been drilled during 2009 and 2010 leading the joint venture to make an initial estimate of recoverable reserves of 110 million barrels of oil. Further prospects on the block suggest additional upside potential towards a total of 350-400 million barrels of total resources. ${ }^{53}$ Further exploration and appraisal work is planned to take place through to 2014 when full field development could begin. Irkutsk's other oil discovery was on the Bolshetirsky block, where a well drilling in Q4 2010 had significant crude inflows, although potential reserve estimates have not yet been made.

The gas discovery is on the Zapadno-Yaraktinsky licence, and although the gas itself will be difficult to commercialise given the small domestic market and lack of export routes, Irkutsk Oil has been making efforts to find markets for its growing gas resources. As early as 2006 the company reached agreement with Gazprom to help provide gas for the gasification of the Irkutsk region, ${ }^{54}$ but the extent of the company's potential gas reserves means that it has now also begun to investigate the development of a GTL project in partnership with JOGMEC. ${ }^{55}$ Although the concept is clearly at an early stage it further demonstrates the desire of Japanese companies to use their technology to help source liquids resources for their home market, and in this case any output could supplement the more easily marketable gas condensate resources owned by Irkutsk Oil.

\section{Conclusions on Irkutsk Oil}

Having started life in 2000 as a small exploration and production company supplying oil and condensate into the local and regional markets, Irkutsk Oil has developed into a growing oil

\footnotetext{
${ }^{52}$ See Irkutsk Oil web-site at http://www.irkutskoil.com/section 29/section 31, accessed Jan $3^{\text {rd }} 2011$

${ }^{53}$ Press Release from Irkutsk Oil, 25 Oct 2010, "Russia: JOGMEC and Irkutsk Oil find oil in 3 East Siberian blocks", Irkutsk

${ }^{54}$ Interfax Russia and CIS Oil \& Gas Weekly, 11 Nov 2006, "Irkutsk Oil to sell Gazprom gas from Markovskoye, Ayanskoye fields", Moscow

${ }^{55}$ Interfax Russia and CIS Oil \& Gas Weekly, 7 Dec 2009, “Irkutsk Oil Co., JOGMEC to prepare GTL feasibility study in 2010", Moscow
} 
producer with significant aspirations to tap export markets in the Far East. The gradual acquisition of a broad spread of licences and a successful exploration programme to prove up more than 300 million barrels of liquids reserves has already made Irkutsk the fourth largest producer in East Siberia, and with a new link to the ESPO set to be established in 2011 the potential for growth in production and export sales is evident, with 75,000 bpd of liquids output a seemingly realistic target for 2015. The company's links with Japan provide not only a ready market for any production but also a source of financing and technology for future growth, and the JV with JOGMEC provides an example of how commercial interests are beginning to break down the political barriers that have hindered relations between Russia and Japan in the post-Soviet era.

\subsection{Slavneft (jointly owned by GazpromNeft and TNK-BP as a 50:50 Joint Venture)}

Slavneft's future as an East Siberia oil producer will largely depend upon co-operation with Rosneft, as the company's core assets are located in the Krasnoyarsk region close to the Yurubcheno-Tokhomskoye field. Given the need for infrastructure development in the area, and in particular a $600 \mathrm{~km}$ link to the ESPO pipeline, it seems likely that Slavneft will need not only to agree a development timetable that fits with the state-owned player in the region but also a sharing of the infrastructure costs. However, the company has identified Krasnoyarsk as an area of strategic growth for the company, and with two fields already discovered and being prepared for production it is likely that Slavneft will be keen to cooperate in any regional development plan.

Slavneft owns seven licences in and around the Evenki municipal district of Krasnoyarsk, with the two most important being Kuyumbinsky and Tersko-Kamovsky where their existing fields are located. The company's 2009 annual report identifies these two fields as holding combined $\mathrm{ABC} 1$ reserves under the Russian classification of 133.4 million tonnes of oil (approximately 1 billion barrels) (Slavneft, 2010, p. 12) while discoveries and other resources discovered to date in the other five licences take the company's total reserves and resource base to 268 million tonnes (approximately 2 billion barrels). ${ }^{56}$ Some analyst reports have suggested even higher figures, with total resources of 2.9 billion barrels suggested for the two fields (Kokin, 2010, pp. 8-9), which implies a level of reserves and resources in excess of TNK-BP's Verkhnechonskoye field, where peak production is expected to be $150,000 \mathrm{bpd}$.

\footnotetext{
${ }^{56}$ Interfax Russia and CIS Oil \& Gas Weekly, 7 Dec 2009, "Slavneft reserves in East Siberia total 268 mln tonnes", Moscow
} 
However, Slavneft is unlikely to realise the production potential of its existing reserve base in East Siberia in the near future. Rosneft's plans for Yurubcheno-Tokhomskoye envisage a first stage of initial development being completed only by 2013, with full-scale production occurring in stages after that. As a result Slavneft is unlikely to be able to develop its fields much before 2015, and therefore short-term output is likely to be restricted to the levels seen in 2009 when production reached 650 bpd for local use only. In the longer term though production from the company's existing assets alone could rise sharply (Kokin, 2010, p. 9), with the Kuyumbinskoye field having potential peak output of 250,000 bpd according to GazpromNeft CFO Vadim Yakovlev, ${ }^{57}$ and with Tersko-Kamovsky having the potential to produce a further 40,000 bpd at peak output. As a result output from these two fields alone could exceed 200,000 bpd by 2020 , before peaking in the middle of the next decade (see Figure 21 below).

Slavneft also has an interest in a further significant asset that could supply the ESPO, although it is located just outside East Siberia in the Yamal region. As with TNK-BP's Suzunskoye and Tagalskoye fields, so Slavneft's Messoyakhinskoye field is located not far to the west of the Vankor field, with potential access to the Vankor-Purpe pipeline. Slavneft has put a considerable exploration effort into the region over the past few years and has already made a number of large discoveries that have allowed the company to recognise $\mathrm{C} 1$ and $\mathrm{C} 2$ reserves totalling 1.7 billion barrels in the Zapadno-Messoyakhskoye and VostochnoMessoyakhskoye fields. ${ }^{58}$ The total resource estimate for the licence area is as high as 5 billion barrels in 15 identified structures, and first pilot production from the existing discoveries is planned to begin in 2013. GazpromNeft, Slavneft's 50\% shareholder, estimates the total ultimate potential output from the area could be as high as 60 million tonnes per annum (1.2 million bpd) but pipeline infrastructure constraints mean that this level is unlikely to be reached even in the medium term. In Figure 21 we estimate that the fields will start full production in 2018 and reach an initial peak of $350,000 \mathrm{bpd}$ by the middle of the next decade.

\section{Conclusions on Slavneft}

Given the proximity of Slavneft's licences to Rosneft's Yurubcheno-Tokhomskoye field the potential development of the company's assets in Krasnoyarsk will hinge largely upon cooperation with Russia's state-owned NOC in the building of new oil infrastructure in the region. As a result, although it is unlikely that Slavneft will be producing much oil there

\footnotetext{
${ }^{57}$ During a Q\&A session with investors during Gazprom's Investor Day in London, $9^{\text {th }}$ February 2010

${ }^{58}$ Slavneft press release, 22 May 2009, "Slavneft invests $190 \mathrm{mln}$ rubles in exploration of new fields located in YANAO", Moscow
} 
before 2015, its Kuyumbinsky and Tersko-Kamovsky fields have the potential to reach combined peak output exceeding 200,000 bpd towards the end of the decade, with further exploration upside also present in the company's five other licences in Krasnoyarsk. Slavneft could further supplement this output by bringing onstream the significant discoveries it is making in the Yamal region at the Messoyakhinskoye licence, which could add an additional 300-400,000 bpd of output during the period 2020-2030 and could possibly produce more than 1 million bpd at its long-term peak. As a result Slavneft could become a significant East Siberia producer over the next ten years, with exports to the Far East dependent upon the construction of transport infrastructure to link with the ESPO both from the Yamal region and from Krasnoyarsk.

\section{Figure 21: Slavneft's potential East Siberian oil production}

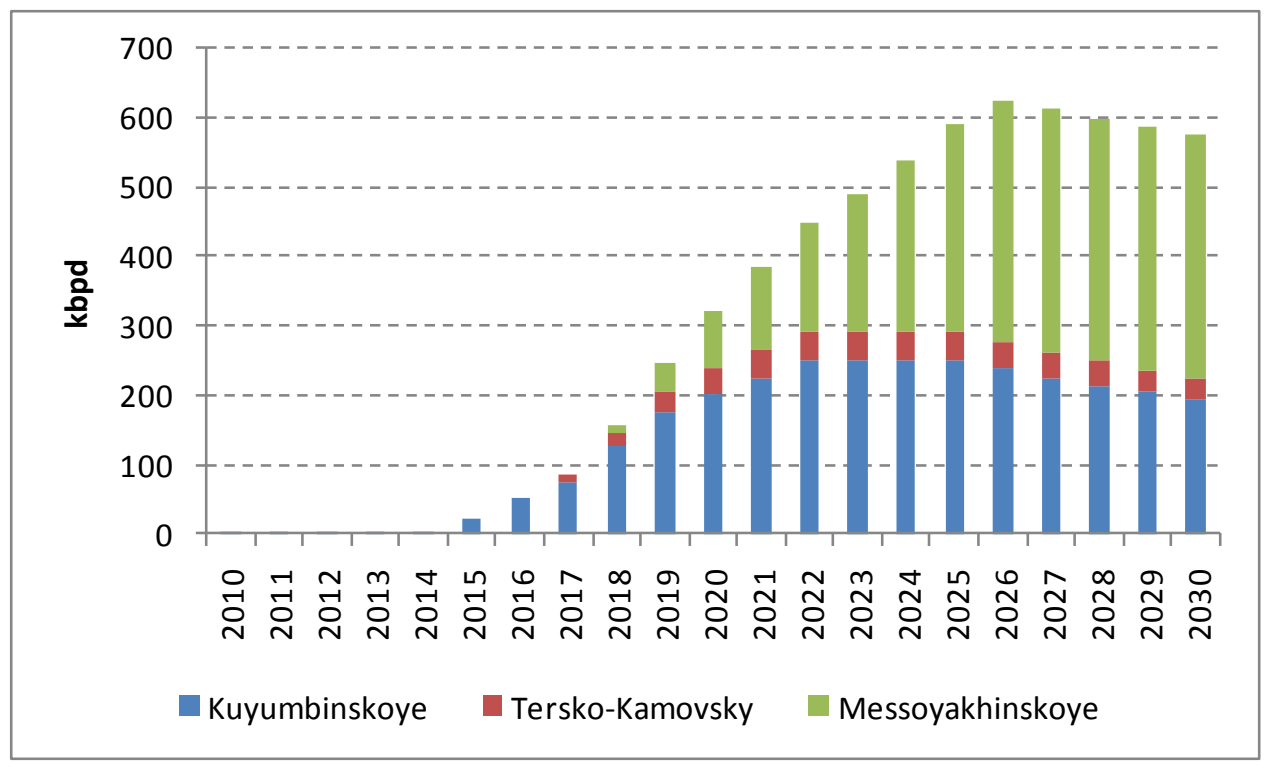

Source: Author's estimates based on company data

\subsection{GazpromNeft}

As a 50\% owner of Slavneft (TNK-BP owns the remaining 50\%) GazpromNeft already has a significant interest in East Siberia, and beyond this investment its direct exposure to the region has remained limited. However, the company did inherit two direct interests in fields in the Krasnoyarsk and Sakha regions from Sibneft, which Gazprom purchased and renamed GazpromNeft in 2005, and it has also announced its intention to send crude through the 
ESPO to Kozmino Bay, ${ }^{59}$ suggesting that an Eastern strategy may be developed over the next few years.

Sibneft acquired its first licence in East Siberia in May 2005 when it won the auction to develop the Srednetaimurinsky block in Krasnoyarsk. ${ }^{60}$ The total resources on the block were estimated at 1.2 billion barrels of oil plus $430 \mathrm{bcm}$ of gas, and the company's eastern portfolio was then further supplemented by the acquisition of the Tympuchikansky block in the Sakha region, with a more modest 124 million barrels of oil resource potential plus 13 bcm of gas. ${ }^{61}$ Following the change of Sibneft into GazpromNeft little interest was taken in these two licences until 2007 when GazpromNeft-Angara was established to promote the development of GazpromNeft's business in East Siberia, which by then amounted to the two licences gained from Sibneft plus two further licences in the Krasnoyarsk region, one more in Sakha and two new licences in Irkutsk. ${ }^{62}$ A drilling programme was planned to commence in 2008, but little further progress has been reported by the company since then, suggesting that the region is no longer a strategic priority for direct investment by GazpromNeft.

\section{Conclusion on GazpromNeft}

Although GazpromNeft does own seven licences across three regions in East Siberia, the company appears to have taken little direct action in the region since the end of 2007. Instead it would appear that it prefers to allow its 50\% interest in Slavneft to provide exposure to the region while it focuses on the development of its core West Siberia business. At some point in the future GazpromNeft's eastern assets may provide some synergy with Slavneft's business there, especially in the Krasnoyarsk region, but for the time being it would appear that there is little prospect of direct GazpromNeft production from East Siberia. As a result, any sales through the ESPO are likely to be sourced from the company's fields in the Tomsk region of West Siberia.

\subsection{Other Small Companies/Assets}

In addition to the assets owned by the large Russian companies outlined above a number of other smaller companies and assets exist in East Siberia that could provide additional output in the region. Perhaps the most interesting of these, because of their recent history, are the

\footnotetext{
${ }^{59}$ Interfax Russia and CIS Oil \& Gas Weekly, 26 Jan 2010, “GazpromNeft to launch oil deliveries from Kozmino sea port", Moscow

${ }^{60}$ Interfax Russia and CIS Oil \& Gas Weekly, 5 May 2005, "Sibneft acquires two new fields, moves into East Siberia", Moscow

${ }^{61}$ Interfax Russia and CIS Oil \& Gas Weekly, 1 July 2005, "Sibneft acquires second field in East Siberia", Moscow

62 Interfax Russia and CIS Oil \& Gas Weekly, 17 Dec 2007, "GazpromNeft sets up a business to develop fields in East Siberia", Moscow
} 
Dulisma and Taas-Yuriakh assets that were owned by Urals Energy until late 2009 but were then transferred to Sberbank in lieu of the repayment of loans that could not be re-financed during the 2008/09 financial crisis. Sberbank has announced that these assets are likely to be for sale in 2011 and they could therefore provide an interesting platform for a new entrant into East Siberia or a supplement to the portfolio of existing players in the region.

The Dulisma field, which Urals Energy had acquired for $\$ 148 \mathrm{~mm}$ in 2006, contains estimated proved and probable reserves of over 460 mmboe (including $142 \mathrm{~mm}$ bbls of liquids), plus a further $105 \mathrm{~mm}$ bbls of possible oil reserves, and prior to the postponement of development due to Urals' financial difficulties the field had been due for production start-up in 2009 (Burgansky, 2008, p. 11). It is located only $75 \mathrm{~km}$ from the ESPO pipeline and Transneft had granted access rights to the pipe prior to the sale of the asset to Sberbank, with peak production set to reach 30,000 bpd within two years of start-up. Gas output from the field was to be used for a local power plant or for sale to Gazprom and total capex for the project had been estimated at approximately $\$ 400 \mathrm{~mm}$.

Sberbank's other major asset in East Siberia is the 35\% stake in Taas-Yuriakh that it also inherited from Urals Energy in 2009 (the remaining 65\% shareholding is owned by a collection of private investors who therefore effectively control the company). ${ }^{63}$ Taas Yuriakh's major asset is the Sredne Botuobinskoye field, and based on a reserve audit by DeGolyer \& MacNaughton in 2007 it would appear that peak production of 130-170,000 bpd was estimated as a reasonable target within five years of first output from a gross reserve base (proved and probable) of approximately $700 \mathrm{~mm}$ barrels of liquids. The field is relatively close to the ESPO (170 km to the north), and before its forced sale to Sberbank Urals Energy had secured the rights from Transneft to connect a spur line from the field in 2009. As a result, it is possible to foresee a further $175,000 \mathrm{bpd}$ of East Siberian production by 2020 if suitable buyers can be found for these two Sberbank fields (see Figure 22).

\footnotetext{
63 Interfax Russia and CIS Oil \& Gas Weekly, 30 Nov 2009, “Urals Energy transfers 35.3\% stake in Taas Yuriakh Neftegazdobycha to Sberbank", Moscow
} 
Figure 22: Potential output from Dulisma and Sredne Botuobinskoye fields

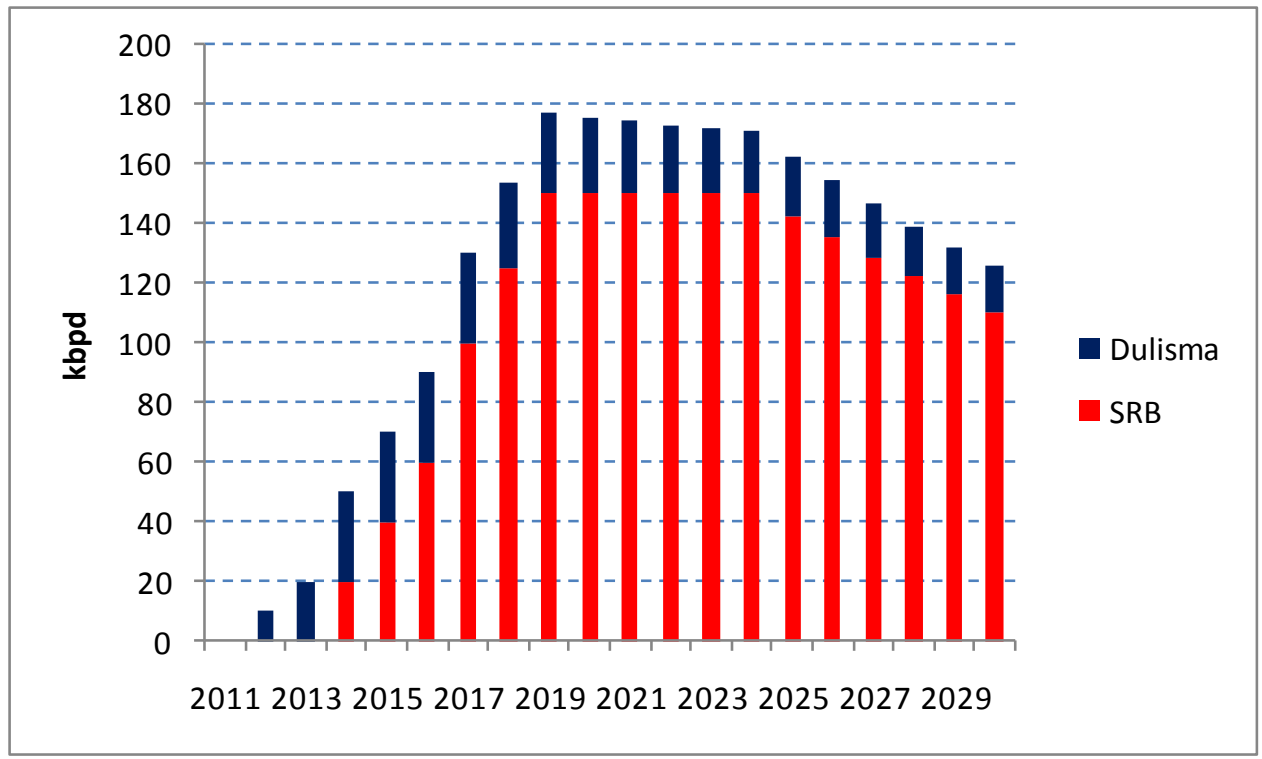

Source: Renaissance Capital, Interfax, Urals Energy

An example of a much longer-term project in the East of Russia is provided by PetroKamchatka, a small exploration and production company quoted on the Toronto Stock Exchange and focused on exploration on the Kamchatka peninsula in the Far East of Russia. The company has acquired interests in seven licences on the west of the peninsula with estimated mean resources of 1.2 billion barrels ${ }^{64}$, and is currently in the middle of a four-well drilling programme that is due to be concluded in late 2011. The exploration programme is clearly high risk, but again has attracted the interest of an Eastern partner, in this case the Korean National Oil Company (KNOC), which has taken a 50\% stake in two of PetroKamchatka's blocks. If an oil discovery is made on the peninsula then significant infrastructure issues will need to be overcome, including the construction of $50 \mathrm{~km}$ of pipeline infrastructure to the nearest shore to allow for shipping of the oil and the need to deal with seasonal ice in the winter months. However, the obvious attraction of the proximity of markets in Japan, Korea and China means that, in the event of significant discoveries being made, these hurdles would be likely to be overcome relatively easily in partnership with potential buyers such as KNOC.

\footnotetext{
${ }^{64}$ DeGolyer \& MacNaughton report of June 30, 2009
} 


\subsection{The Sakhalin Projects}

No analysis of oil production in the East of Russia would be complete without a mention of the Sakhalin projects that have already provided significant output in the region and offer potential for further production increases. Although the projects are not connected to the ESPO, having their own individual export routes via onshore facilities and tankers, they nevertheless have had, and will continue to have, an impact on Far East oil markets that will be further expanded by the full development of the ESPO pipeline. In a sense they provided the initial entry point for Russia to access eastern markets and have also demonstrated the potential benefits, as well as the possible pitfalls, of partnership in the development of oil assets in the region. While a full analysis of the projects would require a separate paper (see for example Bradshaw, 2006), a brief description of the oil reserves and resources of the region is needed to complete the picture of Russia's eastern oil potential, while Map 5 provides an overview of the location of each of the relevant licences.

\section{Sakhalin 1}

The Sakhalin 1 project has already been discussed in the context of Rosneft's involvement, but it should be re-iterated that $80 \%$ of the project is owned by foreign companies, including ExxonMobil (30\%), ONGC (20\%) and the Japanese consortium Sodeco (30\%). Sakhalin 1 was one of the original PSA (production sharing agreement) deals signed by the Russian government in the early 1990s, but significant technological challenges and bureaucratic delays meant that the first of the three fields covered by the agreement did not start producing until 2005. A three-stage development plan was then initiated to develop the project's 1.1 billion barrels of liquids reserves plus $120 \mathrm{bcm}$ of gas, with stage one including production from the Chaivo field starting in 2005 and from the Odoptu field, which came onstream in $2010{ }^{65}$ The Chaivo field has recently entered its decline phase, with output expected to drop from 140,000 bpd in 2010 to 125,000 bpd in 2011, but new production from Odoptu (which will reach 30-35,000 bpd in 2011) will mean that the project as a whole will have output of c. 155,000 bpd in 2011, a small increase on $2010 .{ }^{66}$

\footnotetext{
${ }^{65}$ Oil \& Gas Journal, 29 Sept 2010, "ExxonMobil starts up Sakhalin 1 Odoptu field", New York

${ }^{66}$ Interfax Russia and CIS Oil \& Gas Weekly, 28 Sept 2010, "Sakhalin-1 oil production will rise to 156kbpd in 2011", Yuzhno Sakhalinsk
} 


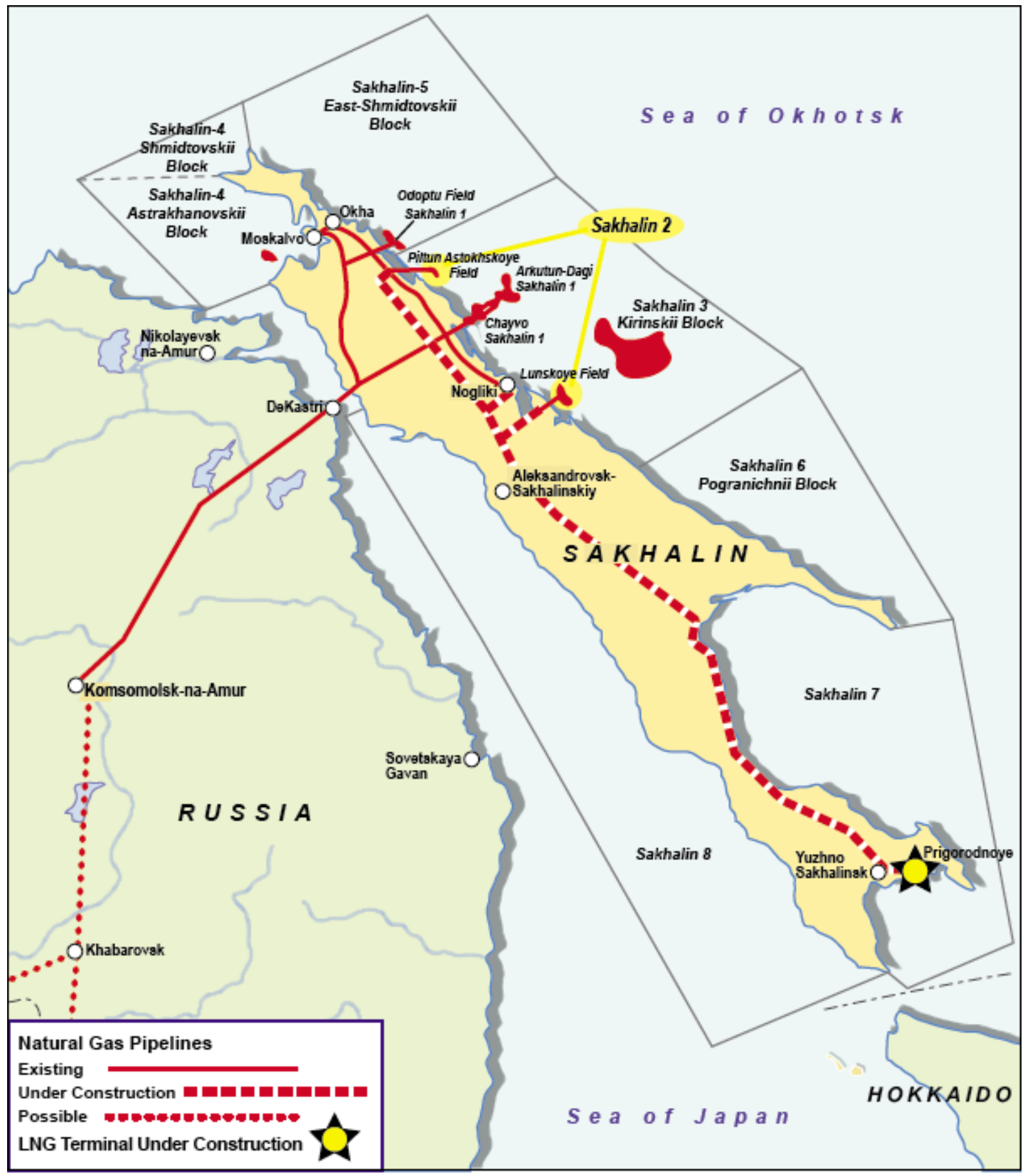

Stage 2 of the Sakhalin 1 development has to date been envisaged as the development of the gas reserves in the Chaivo field, which would not only bring extra revenues but would also help to boost oil production from the field. However, a long-running dispute with Gazprom over where and how the gas should be sold, which has seen ExxonMobil seek export sales in China while Gazprom want to use the gas domestically, ${ }^{67}$ has led to a delay in the

\footnotetext{
${ }^{67}$ Interfax Russia and CIS Oil \& Gas Weekly, 18 Feb 2008, "ExxonMobil, CNPC talks continue on sales of gas from Sakhalin-1", Moscow
} 
development of the reserves which now seem unlikely to be produced before $2015{ }^{68}$ As a result the development of the project's third stage, the Arkutun-Dagi oilfield, is now likely to precede the gas development, with first output planned for 2014, after which total oil output for the Sakhalin 1 project could reach 300,000 bpd by the end of the decade.

However, even this timetable could be undermined by another dispute over project costs and the role of operator for the project. The Russian authorities have recently expressed concern at the rising costs of the overall development of Sakhalin-1, which could ultimately reach $\$ 100$ billion in capital and operating costs, ${ }^{69}$ and it has even been suggested that a Russian company should take over as operator. ${ }^{70}$ The project's budget for 2010 was only passed after a considerable delay, and concern has also been voiced over the inability of the consortium to agree a sales contract, and so although Exxon's position has been re-confirmed for the time being, ${ }^{71}$ the possibility of further delays cannot be discounted, especially if the disagreement over gas sales cannot be solved with Gazprom. Having said that, the technical challenges involved in competing the staged development of the entire Sakhalin-1 project argue in favour of Exxon's ongoing involvement as operator, and this practical reality will most likely lead to an overall solution that will see oil output from the project reaching its planned 300,000 bpd target close to the project schedule.

\section{Sakhalin 2}

The Sakhalin 2 project was also one of the original PSAs agreed in the 1990s, with the current shareholders in the licence being Gazprom (50\% plus one share), Shell $(27.5 \%)$, Mitsui (12.5\%) and Mitsubishi (10\%). Although it is primarily a gas-focused development, with LNG sales of 9.6 million tonnes per annum set to be achieved at peak output in 2011, the first oil output from the Piltun-Astokhskoye field began in 1999. Total oil reserves for the project have been estimated by the former operator Shell at 1 billion barrels (EIA, 2008), but production was initially constrained by the lack of year-round export facilities. As a result output was limited to $60,000 \mathrm{bpd}$ during the summer months until 2009, when phase 2 of the project saw a pipeline built to an ice-free port at Prigorodnoye in the south of Sakhalin Island that has allowed total output to more than double to $150-160,000$ bpd. However, oil

\footnotetext{
${ }^{68}$ Interfax Russia and CIS Oil \& Gas Weekly, 16 Sept 2009, "Sakhalin-1 gas production won't begin before 2015 - Sakhalin governor", Yuzhno Sakhalinsk

69 Interfax Russia and CIS Oil \& Gas Weekly, 14 Oct 2010, “Exxon’s Sakhalin 1 costs could hit \$100bn - paper", Moscow

${ }^{70}$ Interfax Russia and CIS Oil \& Gas Weekly, 26 Oct 2010, “Russian company may become Sakhalin-1 operator Audit Chamber", Moscow

${ }^{71}$ Interfax Russia and CIS Oil \& Gas Weekly, 27 Oct 2010, "Replacement of Sakhalin-1 operator not on agenda Shmatko", Moscow
} 
production has now peaked and is expected to go into decline by the middle of the current decade.

Aside from its physical oil production the Sakhalin 2 project does provide another important driver of developments in the Far East of Russia, namely the importance of the role of the Russian State and its national companies. In this instance the issue of direct Russian participation came to a head in 2006, when negotiations between Shell and its Japanese partners, who then owned $100 \%$ of Sakhalin 2, and Gazprom were only resolved after the controversial interference from the Russian Environmental Agency, who threatened to shut down the project for various licence violations. ${ }^{72}$ The dispute was only resolved when Gazprom was sold a $50 \%$ plus 1 share stake in the project, and effectively only paid past costs for it, at which point the environmental issues were dropped. ${ }^{73}$ The conclusion therefore reached by many commentators ${ }^{74}$ is that the Russian State will certainly dominate all major developments in the region and will enforce its strategy using whatever means are necessary.

\section{Sakhalin 3}

The Sakhalin 3 licence area comprises four blocks that are estimated to contain total resources of 5.1 billion barrels of oil and 1.3 trillion cubic metres of gas. Three of the blocks were originally owned by a consortium comprising ExxonMobil, ChevronTexaco and Rosneft, although the licences were controversially revoked by the Russian Administration in 2004 due to alleged licence violations. ${ }^{75}$ As a result of the re-auctioning of the entire Sakhalin 3 licence, Gazprom now controls three of the blocks (Kirinsky, Ayashky and VostochnoOdoptinsky) with a main focus on developing the estimated $1.4 \mathrm{tcm}$ of gas resources located there, ${ }^{76}$ although the blocks also contain potential oil resources of up to 4.5 billion barrels. ${ }^{77}$ However, initial plans are centred on the development of the Kirinskoye gas field, where 100 bcm of currently estimated reserves are likely to be sold into the Far East market via the Sakhalin-Khabarovsk-Vladivostok pipeline from $2014 .^{78}$

As a result the main oil focus at Sakhalin 3 is likely to be in the remaining Veninsky block owned by Rosneft $(74.9 \%)$ and Sinopec $(25.1 \%)$. Total resources in the block are estimated at

\footnotetext{
72 Oil and Gas Journal, 29 Sept 2006, "Sakhalin 2 project faces more authorisation woes"

${ }^{73}$ New York Times, 18 April 2007, "Gazprom completes Sakhalin 2 takeover"

${ }^{74}$ For example The Economist, 24 May 2007, "Gazprom strikes again?", Moscow

75 The Russia Journal, 29 Jan 2004, “ExxonMobil and ChevronTexaco sacked from Sakhalin”, Moscow

${ }^{76}$ Interfax Russia and CIS Oil \& Gas Weekly, 29 Dec 2010, "ONGC still interested in Sakhalin 3", Moscow

${ }^{77}$ Interfax Russia and CIS Oil \& Gas Weekly, 21 May 2010, "Tax breaks a must for Kirinskoye offshore field Gazprom", Moscow

${ }^{78}$ Data from Gazprom web-site at http://gazprom.com/production/projects/deposits/sakhalin3, accessed 4th Jan 2011
} 
1.2 billion barrels of oil and $260 \mathrm{bcm}$ of gas, and initial exploration drilling was begun in 2006 since when two modest discoveries have been made at the North Veninskoye and Novoveninskoye fields. Exploration and appraisal work is continuing, although it has been reported recently that Sinopec has withdrawn from the project due to the lack of positive results ${ }^{79}$ suggesting that oil production from the block is unlikely in the near future.

\section{Sakhalin 4}

The Sakhalin 4 licence currently holds out little hope for early oil production despite recent interest from international oil companies and the Russian NOCs. The licence comprises two blocks, West Shmidt and Astrakhanovsky, with the former having originally been licensed to a JV between BP and Rosneft. However, following a series of disappointing exploration results licence ownership was renounced in March 2009. ${ }^{80}$ Gazprom has expressed interest in the Astrakhanovsky block, and has been in discussions about a partnership with Shell, ${ }^{81}$ but any exploration is likely to have a gas focus and is unlikely to start in the foreseeable future.

\section{Sakhalin 5}

Sakhalin 5 is another area of co-operation between Rosneft and BP (in a 51\%/49\% JV), and comprises two blocks on the north-eastern part of the Sakhalin shelf. The first, East Shmidt, is located next to the West Shmidt block that is part of the Sakhalin 4 licence, but following the exploration work on Sakhalin 4 and initial analysis of seismic data for Sakhalin 5 it was decided to abandon work in the area ${ }^{82}$ and surrender the block. As a result, all exploration efforts are now focused on the Kaigansko Vasyukansky block, where 13 prospective structures have been identified and where DeGolyer \& MacNaughton have made a preliminary resources estimate of 8.5 billion barrels of oil (EIA, 2008).

To date three successful exploration wells have been drilled, with the last, in March 2007, discovering the Kaigansko-Vasyukanskoye Sea field with estimated ABC1 reserves of 118 mm barrels. ${ }^{83}$ However, discoveries of this size will be difficult to commercialise in the harsh environmental conditions offshore Sakhalin, and as a result Rosneft and BP are re-

\footnotetext{
${ }^{79}$ Upstream Online, 29 Sept 2010, "Sinopec halts work on Sakhalin 3 block", http://www.upstreamonline.com/incoming/article230556.ece accessed 4th Jan 2011

${ }^{80}$ Upstream Online, 2 March 2009, "BP has abandoned the Sakhalin 4 exploration area", www.upstreamonline.com/live/article173200.ece, accessed Jan 4th 2011

${ }^{81}$ Lngpedia.com, 1 July 2009, "Gazprom welcomes Shell back to Sakhalin 3 and 4", www.Ingpedia.com/russiagazprom-welcomes-shell-back-to-sakhalin-3-and-4, accessed Jan $4^{\text {th }} 2011$

82 http://www.rosneft.com/Upstream/Exploration/russia far east/sakhalin-5, accessed Jan $4^{\text {th }} 2011$

83 Interfax Russia and CIS Oil \& Gas Weekly, 29 Dec 2010, "Rosneft, BP to make drilling decision on Sakhalin 5 in mid-2011", Moscow
} 
considering the merits of continuing the drilling campaign, despite the fact that the licence has been extended to 2013. A decision on further exploration plans is expected in mid-2011, but it seems unlikely, even if work were to continue, that any production would occur before 2020.

\section{Sakhalin 6}

Sakhalin 6 is something of an anomaly among the Sakhalin projects as it comprises a small onshore field with a licence area that extends offshore and contains significant exploration prospects. It is also different from the other Sakhalin projects because it is operated by a small company, Petrosakh, that is one of the two remaining subsidiaries of Urals Energy following its financial problems in 2009/10. Petrosakh's current operations are based around the small Okruzhnoye field, where DeGolyer \& MacNaughton estimate proved and probable reserves to be 15.5 million barrels (Butlin, 2010, p. 6). Current production is approximately $1,500 \mathrm{bpd}$ and is transported to a nearby refinery owned by the company from where oil products are sold into the local market. Some crude is also exported, but the real potential of the export market will only be fully tapped if the company can exploit its offshore exploration prospects. However, despite the fact that potential resources offshore are estimated at 600 million tonnes ( 4.5 billion barrels) ${ }^{84}$ only one well has been drilled to date and the exploration licence is due to expire in 2011. The company is currently seeking investors to partner it in the drilling of a further well, but if this cannot be achieved by the end of 2011 then the licence is likely to be revoked and re-auctioned. As such, progress on the development of these potential liquids reserves is likely to be slow.

\section{Other Sakhalin licence areas}

In March 2010 Rosneft was awarded a new Sakhalin licence in the south-eastern part of the Sakhalin Gulf which contains a number of potential hydrocarbon structures but which is only at the very first stages of exploration work, and so has no resource estimates as yet. ${ }^{85}$ The company has stated that it may bring in partners to assess the full potential of the licence, but confirmed that it is only at the initial stages of the decision-making process. ${ }^{86}$

\footnotetext{
${ }^{84}$ Interfax Russia and CIS Oil \& Gas Weekly, 24 Dec 2010, “Urals Energy seeking investors for Sakhalin-6", Moscow

${ }^{85}$ Interfax Russia and CIS Oil \& Gas Weekly, 3 Mar 2010, "Rosneft gets new Sakhalin license without tender", Moscow

${ }^{86}$ Interfax Russia and CIS Oil \& Gas Weekly, 28 Sept 2010, "Rosneft may bring in partners to develop new Sakhalin blocks", Moscow
} 
Sakhalin Island provided Russia's first significant oil production in the Far East and its first access to Asian oil markets when the Sakhalin 2 project produced its first oil in 1999. The region clearly has huge potential, with total recoverable reserve estimates for the area seen at a level of 7 billion barrels of oil plus more than $2 \mathrm{tcm}$ of gas, and with exploration resources having the potential to more than double this figure (EIA, 2008). However, the seven projects that have so far been licensed are at widely differing stages of development, with only Sakhalin 1 and 2 likely to provide significant production in the period to 2020. In particular, output from Sakhalin 1 is expected to double over the next ten years, and while Sakhalin 2 output will go into gradual decline the expectation is that overall oil output from Sakhalin will rise from around $300,000 \mathrm{bpd}$ in 2010 to between 400 and 500,000 bpd in 2020, depending upon field performance and exploration results (see Figure 23). ${ }^{87}$ Beyond that, the Sakhalin 3 and 5 projects seem to hold out the most hope for further growth, but it is too early to make any definitive estimates of production potential.

\section{Figure 23: Potential output from Sakhalin Island projects}

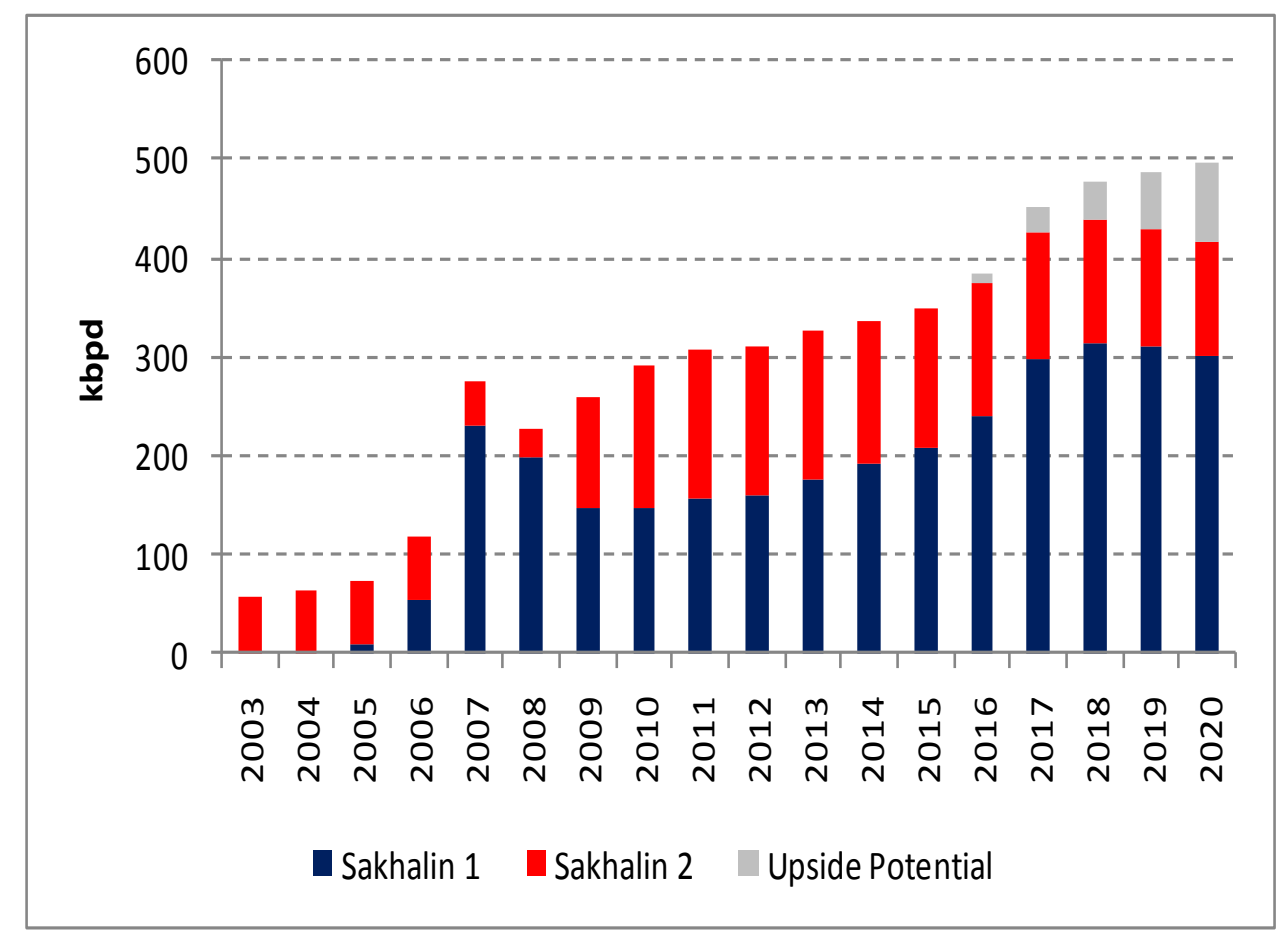

Source: Wood Mackenzie Consultants, Author's estimates

\footnotetext{
${ }^{87}$ Interfax Russia and CIS Oil \& Gas Weekly, 12 Oct 2010, “Oil production in Sakhalin to increase to $15 \mathrm{mmt}$ in 2010", Moscow
} 


\section{Overall Conclusions}

\subsection{Russian Oil Supply from East Siberia and the Far East regions}

The hydrocarbon potential of Russia's eastern regions has been apparent since the Soviet era, when the authorities imagined that oil and gas production from the area would supplement and ultimately replace West Siberian output. A lack of funds and the continued success of the oil and gas sector in the west of the country meant that it was not until the 1990s that serious exploitation of eastern fields was initiated, beginning with the offshore Sakhalin projects in the Far East of Russia. However, although the remoteness of these projects was an attraction to the international investors who were wary of the post-Soviet business environment and were keen to develop fields with direct access to an export market, it did not enable Russia to create a solid base of infrastructure to encourage further eastern oil and gas development. Indeed the original Sakhalin 1 and 2 projects remained Russia's only significant eastern oil and gas investments from their original inception in 1994/95 until 2008, when production from mainland East Siberia began in earnest.

The reasons for the delay in field development on mainland Eastern Russia have been numerous. Firstly, many of the fields are technically challenging and are located in remote areas with little transport infrastructure, meaning that capital and operating costs are relatively high compared to the existing producing areas in West Siberia and European Russia. Secondly, the high tax burden that the Russian Administration has applied to its oil and gas producers over the past decade, while arguably appropriate for existing fields in an era of rising oil prices, has not incentivised new field developments in remote areas such as East Siberia. Thirdly, the markets for East Siberian oil and gas exports have not been easily available. In part this has been because political relations with the obvious buyers of Russia's hydrocarbon exports in the East, China and Japan, have been difficult and lacking in the trust that would encourage either side to become a dependent buyer or seller of strategic energy supplies. This uncertainty has been exacerbated by the other major delaying factor, a lack of hydrocarbon transport facilities. Although oil exports have been sold to China by rail since 1999 (Allen \& Henderson, 2001, p. 13), the full exploitation of East Siberia's oil resources could not be achieved until major pipeline infrastructure had been put in place both inside Russia to the Pacific coast and across China to that country's major refining centres.

These obstacles to investment in field development in East Siberia have gradually been removed over the past five years, to the extent that the region has now become a strategic priority for Russia's oil and gas sector. In particular the development of regions such as 
Yamal-Krasnoyarsk (where Vankor is located) as well as the Irkutsk and Sakha regions of East Siberia are seen as vital to meet Russia's oil supply $\operatorname{targets}^{88}$ and to supplement the expected decline in oil exports to western markets. ${ }^{89}$ The oil industry in particular now stands on the verge of a major eastern expansion as the Russian State, Asia-Pacific buyers and Russian and international corporations have shown ever-increasing enthusiasm for the region. The Russian Administration, concerned about the lack of economic development in the east of the country, has now provided significant investment incentives. Major pipeline infrastructure, in the form of the ESPO, has now been built by state-company Transneft and preferential transport tariffs are being charged. The pipeline came into operation in December 2009 and its capacity will be expanded from the current 600,000 bpd to a potential 1.6 million bpd over the next decade. Furthermore, the pipeline not only reaches to the Pacific coast but also has a spur into China, where the Chinese Administration has now completed its own $900 \mathrm{~km}$ section of the pipe. In Russia, tax incentives have also been introduced in the form of mineral extraction tax holidays and reduced export tax rates, providing a major boost to the economic returns from East Siberian fields. These tax breaks remain short-term at present, reducing the economic security for investors in new fields, but a current review of the country's oil tax system could provide greater long-term direction by the end of $2011 .{ }^{90}$

This increased state support for the oil industry in East Siberia has reduced the impact of the higher cost of operating in the region. As a result companies have invested in seismic work and exploration drilling, encouraging the growth of the service sector in the area and creating a further incentive to cost reduction, as an industry infrastructure of competing companies begins to emerge. Perhaps even more importantly, though, the demand for Russian crude in Asia-Pacific markets has now reached a level where previous political obstacles to interaction with Russia have been overwhelmed by the commercial necessity of securing a diversity of oil imports. China's relationship with the Russian oil sector was sealed with the $\$ 25$ billion loan offered to Transneft and Rosneft in 2009, and it will now receive at least 300 million tonnes of crude over the next 20 years (equivalent to 300,000 bpd). Japan's political dispute with Russia over the Kuril Islands, although ongoing, has not prevented investment by statecompany JOGMEC in oil assets in Irkutsk (adding to Japan's existing investment in the Sakhalin 2 project) and Japan is expected to be a major buyer of ESPO crude as it arrives at the Pacific coast. Other Asia-Pacific countries such as Vietnam, Singapore and Thailand are

\footnotetext{
${ }^{88}$ Interfax Russia and CIS Oil \& Gas Weekly, 16 Aug 2010, “East Siberia alone not enough to achieve $50 \mathrm{mln}$ tpa oil in Russia by 2020", Moscow

89 Reed, A., 24 Aug 2010, “Growing Premium for Russian Crude”, New York

${ }^{90}$ Interfax Russia and CIS Oil \& Gas Weekly, 8 Dec 2010, "Energy Ministry to summit new tax plan to govt. Commission in Q1 2011 - Shmatko", Moscow
} 
also now viewing Russian ESPO crude as a welcome source of diversification from Middle Eastern and West African imports, especially as the Asia-Pacific region's oil import requirement is expected to grow at $2.5 \%$ per annum over the next twenty years (EIA, 2010a).

With the commercial and political obstacles of hydrocarbon development in Eastern Russia having been largely addressed the key question is then whether the existing and future resources of the region can meet supply expectations. An analysis of the main corporate players suggests that the answer to this question is yes, although the exact timing of future production levels remains somewhat speculative. Nevertheless it would appear that five core regions in Eastern Russia, four in what can broadly be defined as East Siberia and one in the Far East, do have the potential to produce over 2 million barrels per day of oil by 2020, with the potential to reach $2.5 \mathrm{mmbpd}$ beyond that.

\section{Figure 24: Future oil supply potential from Eastern Russia}

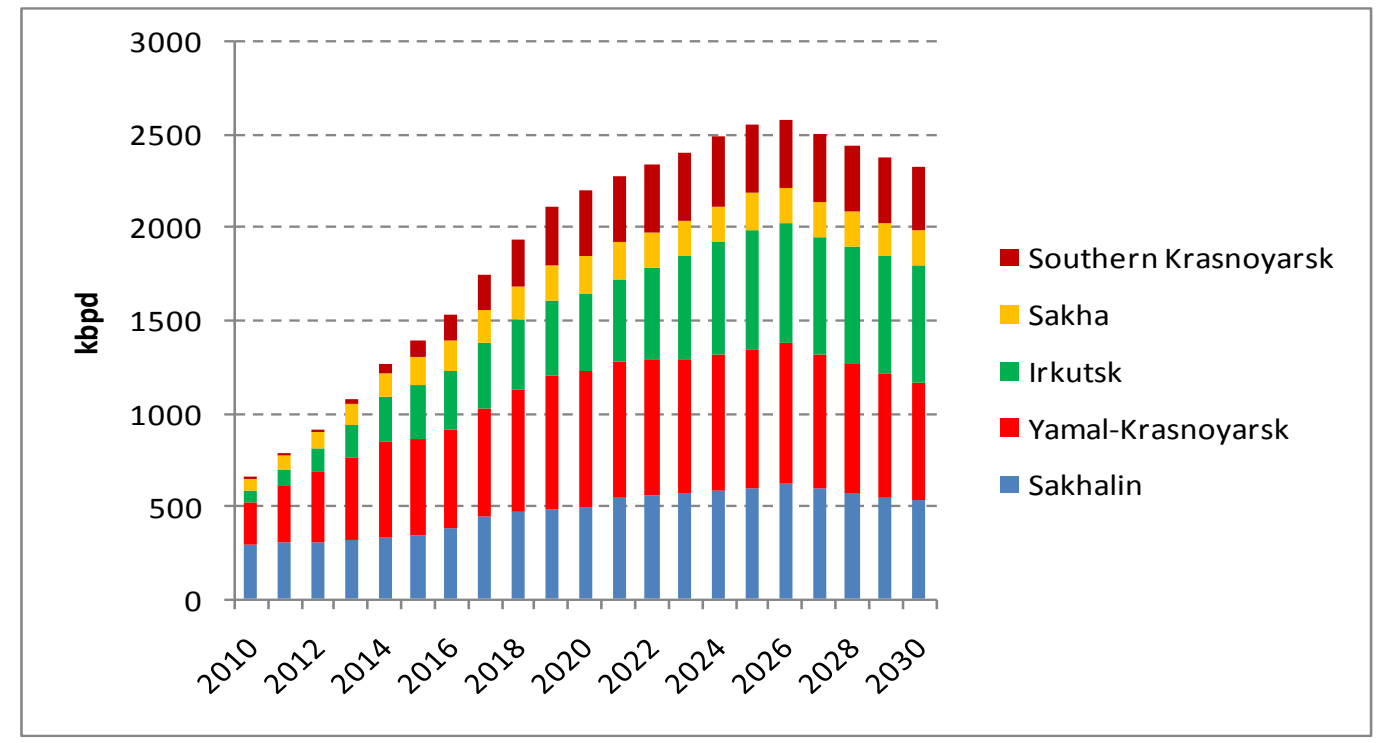

Source: Author's Estimates based on Company Data

Oil has been produced in small quantities onshore Sakhalin Island since the Soviet era, but the major expansion of output in the post-Soviet era came with first production from the offshore Sakhalin 2 project in 1999. Sakhalin 1 then came onstream in 2005 and until 2008 these two projects accounted for almost all of Russia's eastern oil output. The importance of the region to Russia's oil production, however, is in decline as onshore production in East Siberia increases, but output from the area could still reach 500,000 bpd by 2020 if Sakhalin 1 production increases as expected and if one major new project should come onstream from the current exploration prospects and discoveries at the other Sakhalin licence areas. 
However, the major short-term growth in Russia's east-facing production is likely to come from the Yamal-Krasnoyarsk region in the north-west of East Siberia, where Rosneft's Vankor field is located. Vankor production is set to reach a peak of 510,000 bpd within the next two to three years, and output from the region is likely to be supplemented over time by new discoveries in the Vankor area as well as by fields in the Yamal area where TNK-BP and Slavneft have significant reserves awaiting development. Although these fields are strictly in West Siberia, the key to opening this region will be the establishment of a link to the east through the construction of a pipeline to connect via the Zapolyarnoye field to Purpe, which would allow oil production to reach the ESPO via the existing trunk pipeline system. Official sanction to build the pipeline has been granted, ${ }^{91}$ and although the debate about financing the project continues between Transneft and the potential users of the pipe it is likely that the planned timetable of a 3-stage opening between 2013 and 2015 will be met, with an ultimate capacity of $900,000 \mathrm{bpd}$. When the capacity of this new pipe is added to the existing capacity of the Vankor-Purpe line $(500,000 \mathrm{bpd})$ the region will therefore have the infrastructure in place to export 1.4 million bpd. The current assets in Yamal-Krasnoyarsk are estimated to have peak productive capacity of approximately 750,000 bpd (see Figure 24 above) and so there is likely to be ample spare capacity for new discoveries in the region, which is set to remain a key producing area throughout the next two decades with the flexibility to send oil both east via the ESPO and west via the existing Transneft pipeline system.

Further east the Irkutsk region is likely to be the area of fastest output growth in Russia over the next decade if full field development potential can be achieved. The core field in the area at present is Verkhnechonskoye, where TNK-BP and Rosneft are partners, while Irkutsk Oil has a small but growing production base in four smaller fields and the former Urals Energy assets, now controlled by Sberbank, are awaiting full development. The major upside, however, is in the licence areas acquired by Rosneft around Verkhnechonskoye, where one significant 1 billion barrel discovery has already been made and where total resources are estimated at 8 billion barrels. The production assumption shown in Figure 24 assumes that only one new field is developed in the next decade, with regional output reaching 400,000 bpd by 2020 and 650,000 by 2025 as a result, but the resource potential suggests that this is likely to be a very conservative assumption. Directly north of Irkutsk the Sakha region also has significant growth potential based on the assets owned by Surgutneftegas around the Talakanskoye field, as the company has a strategic ambition to grow its output in the area. A

\footnotetext{
${ }^{91}$ Interfax Russia and CIS Oil \& Gas Weekly, 17 May 2010, “Russian govt gives go-ahead to Zapolyarnoye-Purpe pipeline", Moscow
} 
second producing field, Alinskoye, has also been supplemented by six other discoveries that have been placed on the list of tax-exempt fields, suggesting that output from the region could triple to 200,000 bpd by 2020 .

Oilfields in Southern Krasnoyarsk also offer the potential to create a major hydrocarbon centre, with initial development likely to be focused on Rosneft's Yurubcheno-Takhomskoye field. However, of all the onshore regions identified so far Southern Krasnoyarsk is furthest from the ESPO and therefore will require the greatest expenditure on new infrastructure, with $400-600 \mathrm{~km}$ of pipe required to link most of the fields to the trunk pipeline. Slavneft is the other main operator in the region, with the Kyumbinskoye field its major asset, and it will most likely need to co-operate with Rosneft to find the optimal transport outcome over the next few years. Given the difficult issues this will probably involve we suspect that the region will not be fully developed until the second half of this decade, but output could still reach 350,000 bpd by 2020 and be sustained at that level until 2030 .

\section{Figure 25: Eastern Russia oil production by company}

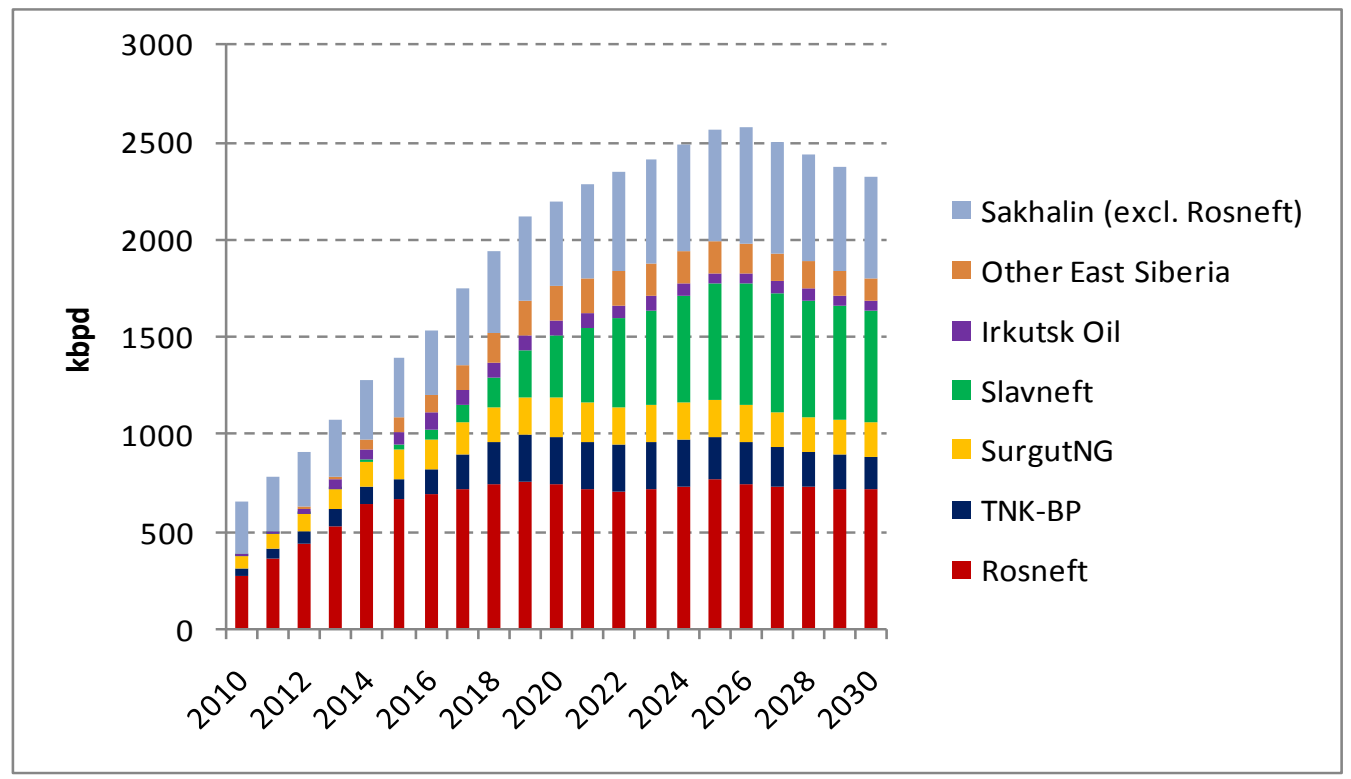

Source: Author's Estimates based on Company Data

From a corporate perspective Rosneft is set to be the driving force behind the growth in Russia's eastern production growth over the next two decades. The company has significant positions in four of the five regional areas discussed above (with Sakha being the current exception) and could see its output from Eastern Russia triple to 750,000 bpd by 2020 . Beyond that date further growth will rely on exploration results and so is not fully reflected in Figure 25, but with even a moderate level of drilling success the company could be producing 1 million bpd in East Siberia by 2030. TNK-BP and Surgutneftegas are the other main 
producers at present, and both have growth potential based on their existing fields and new developments. TNK-BP's Verkhnechonskoye field should reach peak output by 2017, by which time the company's fields in the Yamal-Krasnoyarsk region should also be onstream, leading to overall eastern output of up to $250,000 \mathrm{bpd}$ by 2020 . Surgutneftegas, on the other hand, is likely to remain focused on the Sakha region, where the eight fields it owns on the tax-exempt list, based around the Talakanskoye field, could lead to output of 200,000 bpd on a similar timescale. East Siberia's fourth largest current producer, Irkutsk Oil, could see its output increase by a factor of five times to reach 75-80,000 bpd by 2015 if the development plans for its current assets are met, and its joint venture with Japanese partner JOGMEC has already made exploration discoveries that could sustain longer-term growth.

However, the company with the greatest growth potential is Slavneft, jointly owned by GazpromNeft and TNK-BP, which has exposure to large fields in Yamal-Krasnoyasrk and Southern Krasnoyarsk. All of its assets are dependent on the construction of new pipelines, but the new political and corporate focus on Russia's East means that the momentum to build the infrastructure that will enable commercial development of new fields is strong. As a result the company could go from zero eastern production to output of over 300,000 bpd by 2020 , with the potential to double that figure again by 2030 if its main fields are developed. Of all the estimates in Figure 25 those for Slavneft have the highest risk attached, but the fact that the company represents state-owned GazpromNeft's major exposure to Eastern Russia provides some hope that its targets will be fulfilled.

Other assets identified in East Siberia include the former Urals Energy fields now controlled by Sberbank, which will require a new owner if their potential is to be realised. The assets are currently for sale and therefore the timing of the production estimates is clearly speculative. Figure 25 also groups all the Sakhalin liquids production together (excluding Rosneft's share of Sakhalin 1), and is based on Sakhalin 1 and 2 output to 2020, with an assumption of one more field development thereafter.

\subsection{Key risks to the potential growth of oil production in the Russian East}

However, while the potential for oil output in Russia's eastern regions is clearly large, it would be wrong not to acknowledge some important risks to the development of that potential. The most obvious risk is the ongoing difficulty presented by the regions' geography and geology. Despite the building of the ESPO transport infrastructure remains scarce, and when this is combined with the extra cost of importing oil service equipment and personnel the commercial returns from any project can be quickly undermined. Furthermore, 
the formation of many of the oilfield reservoirs in East Siberia is different to those seen in the west of the region, again with potential consequences for cost and exploration risk. Comments from TNK-BP about its Verkhnechonskoye field highlight the potential problems:

To say that Verkhnechonskoye is remote is an understatement. It lies 4,000 kilometres from Moscow... and the nearest airport is located in the township of Yerbogachen, a rural outpost where horses graze alongside the airfield. [In addition] Verkhnechonskoye is different from the majority of oil reservoirs... "There isn't, actually, a lot of production experience around the world from rock like the one in Verkhnechonskoye", says Francis Sommer, TNK-BP Vice President for Production Technology. Most oil accumulations in West Siberia date back to the more recent, Jurassic period, where the rock is less hard due to less compression over time... One of the central challenges of the field is how to work in the hard rock. There is also a lot of salt embedded in the rock. Both factors mean that conventional drilling is not efficient. (TNK-BP, 2008)

However, these challenges, or at least the cost of them, can be alleviated by the introduction of a tax system that incentivises investment and risk-taking. Until 2009 East Siberia fields were taxed in the same way as the mature producing assets in West Siberia, with the main element of the tax system being two revenue-based taxes, MET and the Export Duty. Following a series of changes during 2009 and 2010, 22 East Siberian fields now pay a reduced export duty and zero MET, but the tax that is paid is still largely revenue based and does not allow for the cost recovery that is essential to the economics of new fields. As a result, companies are still questioning the true economic incentive to invest, especially as the tax breaks are removed when a 15\% IRR cap has been reached. Furthermore, the potential for further changes in the tax system is high, as a debate about the whole structure of oil taxation in Russia is ongoing (Davletshin, 2011), and although the outcome is unlikely to be negative for East Siberian fields the continued uncertainty is not helpful to oil companies.

In addition, the ongoing global economic crisis and the struggle that Russia is currently facing to balance its budget is providing the Russian authorities, mainly through Finance Minister Alexei Kudrin, with a strong argument for increasing rather than reducing oil industry taxes. One current example of the debate is focused on whether tax exemptions for 
the Vankor field should be extended, ${ }^{92}$ with field operator Rosneft arguing that further growth in output needs tax breaks while the Finance Ministry sees no such justification at current oil prices. Vladimir Bogdanov, the CEO of Surgutneftegas, another company with significant East Siberia exploration and production interests, has added his support to the oil industry lobby, stating in mid 2010 that "the potential increase in oil output [for the company as a whole] will largely be determined by tax policy for Eastern Siberia", 93 emphasizing the importance of the issue to Russia's overall production prospects. Given the increasing political focus on the Russian East and the need to find alternative regions to bolster the country's crude output, it would be a surprise if East Siberian tax breaks were undermined completely, but there is nevertheless a clear risk that should government policy change, or be overwhelmed by other fiscal imperatives, then the prospects for the oil and gas industry in East Siberia could suffer as a consequence.

One final broader risk is that the incentive for Russian oil companies to send oil east rather than west may not fully materialise. This could be caused by geo-political factors, such as the ongoing dispute with Japan over the Kuril Islands, or commercial factors, such as the potential to sell oil into competing markets in the Atlantic Basin or the Mediterranean that exists for some of the more westerly fields in East Siberia. However, while this competing market opportunity is clearly present for fields close to the existing Transneft system, such as Vankor or the fields in the Yamal region, the real driver of exports to the East will be the pull from demand centres in the Asia-Pacific region. If China's relations with Russia continue to improve and the spur line of the ESPO is expanded to its full capacity, then the price to be paid for any oil exports is likely to be at global levels thus undermining any competition from other buyers. Furthermore, if Asian importers become increasingly keen to diversify their supply risk away from Middle Eastern producers, then again Russian oil is likely to be in higher demand and the incentive for Russian producers to export east will increase. The converse of these arguments is also of course possible, and if, for example, Russia's negotiations with China over gas export prices break down in acrimony then this could have a broader impact on the growth in oil exports.

However, having outlined these three key risks, the commercial reality of growing oil demand in China and the Asia-Pacific region as a whole combined with the potential for growing supply in Russia would appear to provide a strong basis for believing that the

\footnotetext{
${ }^{92}$ Interfax Russia and CIS Oil \& Gas News, "No decision yet on extending discount for Vankor oil - Kudrin", 2 Feb 2011, Moscow

${ }^{93}$ Interfax Russia and CIS Oil \& Gas News, "Surgutneftegas' production growth is only possible thanks to tax breaks in East Siberia - Bogdanov", 25 June 2010, Moscow
} 
export-import trade in oil and oil products will increase rapidly. Infrastructure issues will be resolved as the industry grows, geological risk is unlikely to prevent long-term development given the progress already made at a number of fields and licences, and the Russian government is likely to continue to provide tax incentives as its eastern regions will remain a vital strategic priority for decades to come. Therefore, although the development of any new hydrocarbon province is never without significant risks, the commercial logic behind the development of hydrocarbons in East Siberia would appear to be strong enough to mitigate their likely impact.

\subsection{The potential impact of East Siberian crude on Russia's overall production and exports}

It appears, therefore, that Russian oil companies, led by Rosneft and encouraged by the incentives offered by the Russian Government, are increasingly focused on developing the oil resources of East Siberia and Russia's Far East. Further, it would also seem likely that the resources are technically available in the region to generate a significant boost to production, with a theoretical potential as high as $2.5 \mathrm{mmbpd}$, if a reasonable amount of exploration success is assumed. Of this total $500-600,000 \mathrm{bpd}$ is likely to come from Sakhalin Island, in particular the Sakhalin 1 and 2 projects, but the remaining 2 million barrels per day will be produced onshore in East Siberia and then transported to domestic and export markets via the expanding ESPO pipeline. As can be seen in Figure 26, it is not difficult to create a scenario in which the ESPO can be expanded to its full $1.6 \mathrm{mmbpd}$ capacity by 2020 and be filled with East Siberian crude.

Figure 26: Eastern Siberia oil production and ESPO capacity

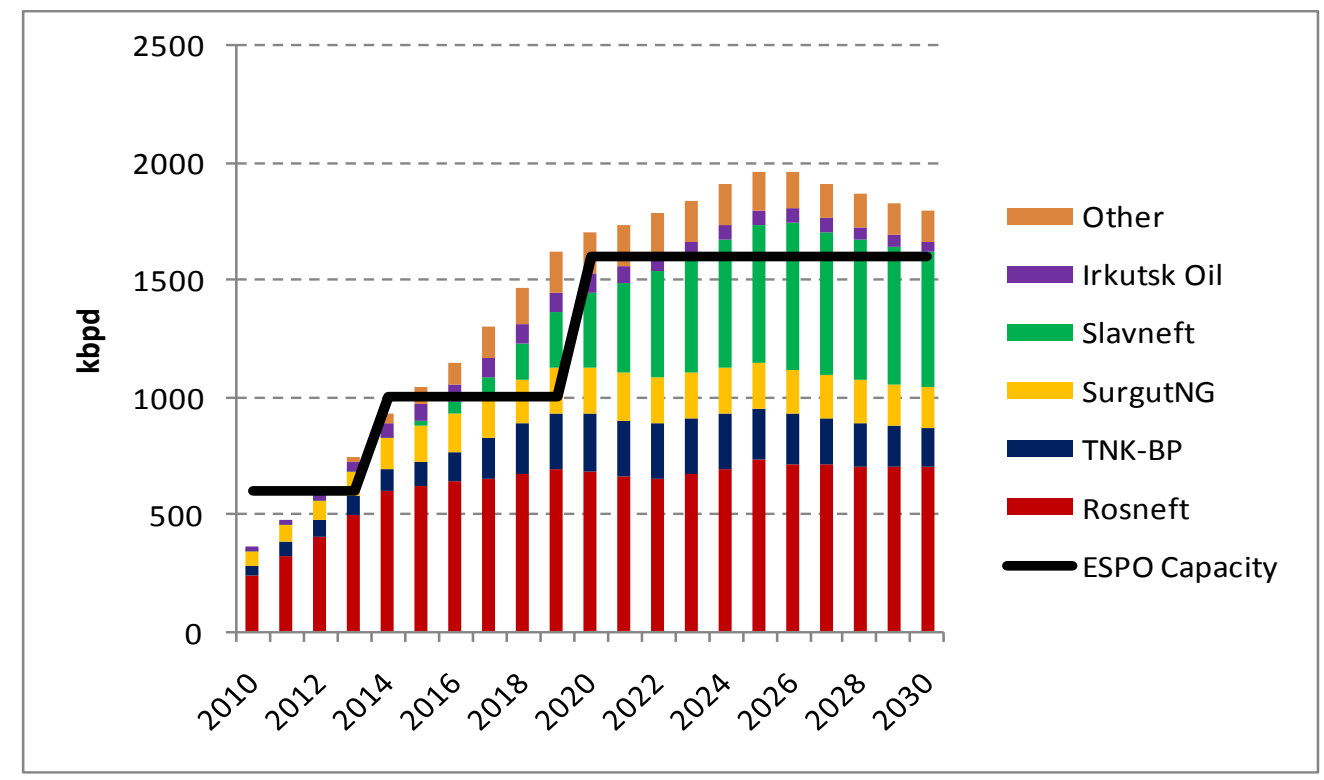


As a result it would appear very likely that the Russian Government's target of $1.5 \mathrm{mmbpd}$ of East Siberian oil production by 2030 can be met or even exceeded, and that this growth will enable Russia to maintain its overall oil output at or above $10 \mathrm{mmbpd}$. Furthermore, it also seems very feasible to assume that Russia's oil exports to Asia will increase along the same trajectory towards the government's target of $1.3 \mathrm{mmbpd}$ by 2030 . Indeed it is interesting to note that oil output from East Siberia and Russia's Far East is already playing a key role in maintaining the country's oil production and exports. In 2010, for example, overall Russian oil production rose by $2.2 \%$ from $9.92 \mathrm{mmbpd}$ to $10.15 \mathrm{mmbpd}$, an increase of 230,000 bpd. ${ }^{94}$ Over the same 12-month period production from the Vankor field rose by $182,000 \mathrm{bpd}$ and output from Verkhnechonskoye increased by 31,000 bpd (Rosneft, 2011), Surgutneftegas's East Siberian output increased by 17,000 bpd ${ }^{95}$ and Irkutsk Oil's production rose by 7500 bpd. $^{96}$ As a result the growth in East Siberian production, which totalled $237,500 \mathrm{bpd}$, accounted for $103 \%$ of Russia's total production increase in 2010, demonstrating that the region is already making up for declines elsewhere in the country.

A similar story is also emerging in terms of Russia's crude exports. Figure 27 shows that prior to the start-up of the ESPO in December 2009 Russia was exporting between 400$500,000 \mathrm{bpd}$ of crude to Asian markets via a combination of tankers from Sakhalin Island and rail transport to China. In 2010 the level of exports jumped by almost 300,000 bpd as the ESPO opened as far as Skovorodino, allowing onward transport of crude to Kozmino Bay on the Pacific Coast. From January 2011 ESPO exports will jump by up to a further 300,000 bpd as the spur pipeline from Skovorodino to the Chinese border also becomes operational, although this will probably reduce rail exports to China and so the overall total will rise only by a further $100,000 \mathrm{bpd}$ to approximately $900,000 \mathrm{bpd}$. As a result it is again apparent that exports from Eastern Russia to Asia have already started to replace the declining sales to Europe that can be seen appearing through 2010. Although the effect is only marginal at present it is expected to accelerate over the next three years, with exports to Europe estimated to decline by 600,000 bpd between 2009 and 2014 while exports to Asia should have increased by around 800,000 bpd over the same period (Reed, 2010).

\footnotetext{
94 Interfax Russia \& CIS Oil and Gas Report, 11 Jan 2011, “Oil production in Russia up 2.2\% in 2010”, Moscow

95 Platts Oil News, 5 Oct 2010, "Russia's Surgut eyes doubling of East Siberian oil output by 2015"

${ }^{96}$ Irkutsk oil web-site at http://www.irkutskoil.com/presscenter/companynews?id=30, "Crude production is growing", accessed 18 Feb 2011
} 
Although it is too early to say what impact this increase in Russian exports will have on the Asia-Pacific crude market, it is nevertheless interesting to note the diversity of buyers that has already emerged, ranging from the traditional markets of South Korea and Japan to newer buyers such as Thailand, the Philippines and even the USA (see Figure 28). Furthermore, although in 2011 Russia will only account for 4-5\% of Asia-Pacific oil imports, by 2020 this figure could be approaching 10\% if the full capacity of the ESPO is built and filled. As discussed in the Rosneft section above, these ESPO-sourced sales may combine crude oil and oil products if the new Primorye refinery is built on Russia's eastern seaboard, but nevertheless the increase in overall oil exports from Eastern Russia will be significant over the next decade.

\section{Figure 27: Russia crude oil exports to Europe and Asia}

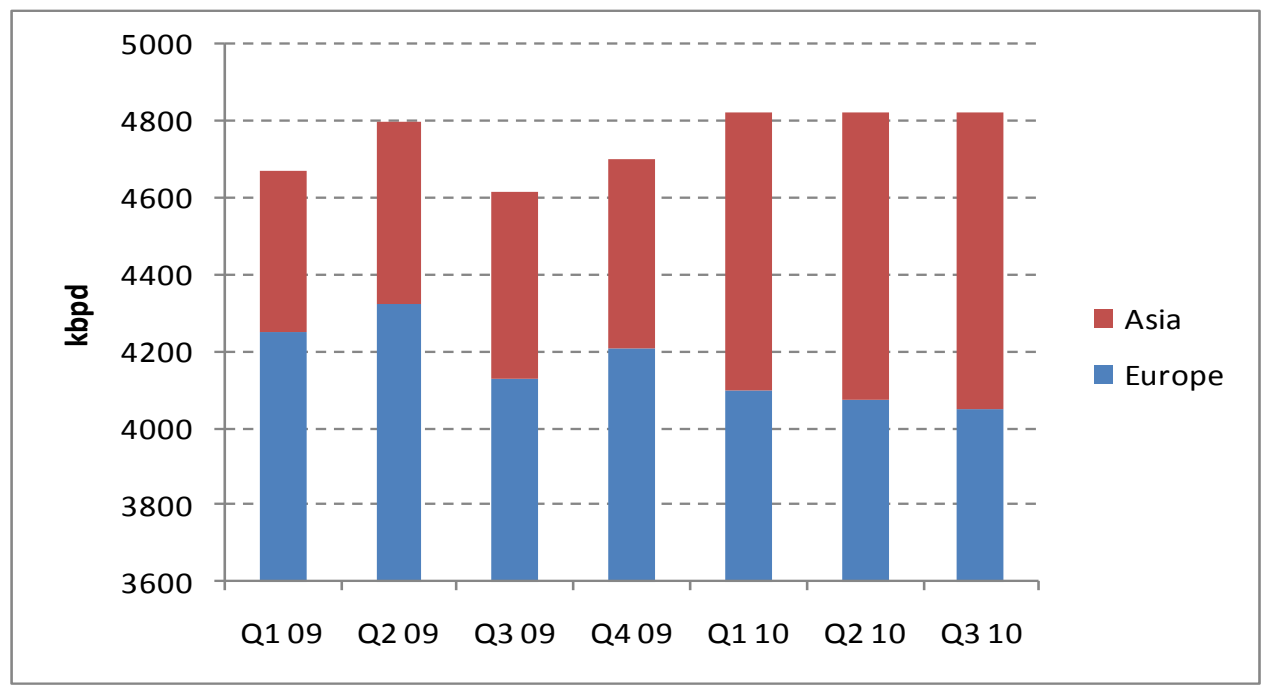

Source: Energy Security Analysis Inc.

Figure 28: ESPO crude exports by destination (December 2009 to October 2010) 


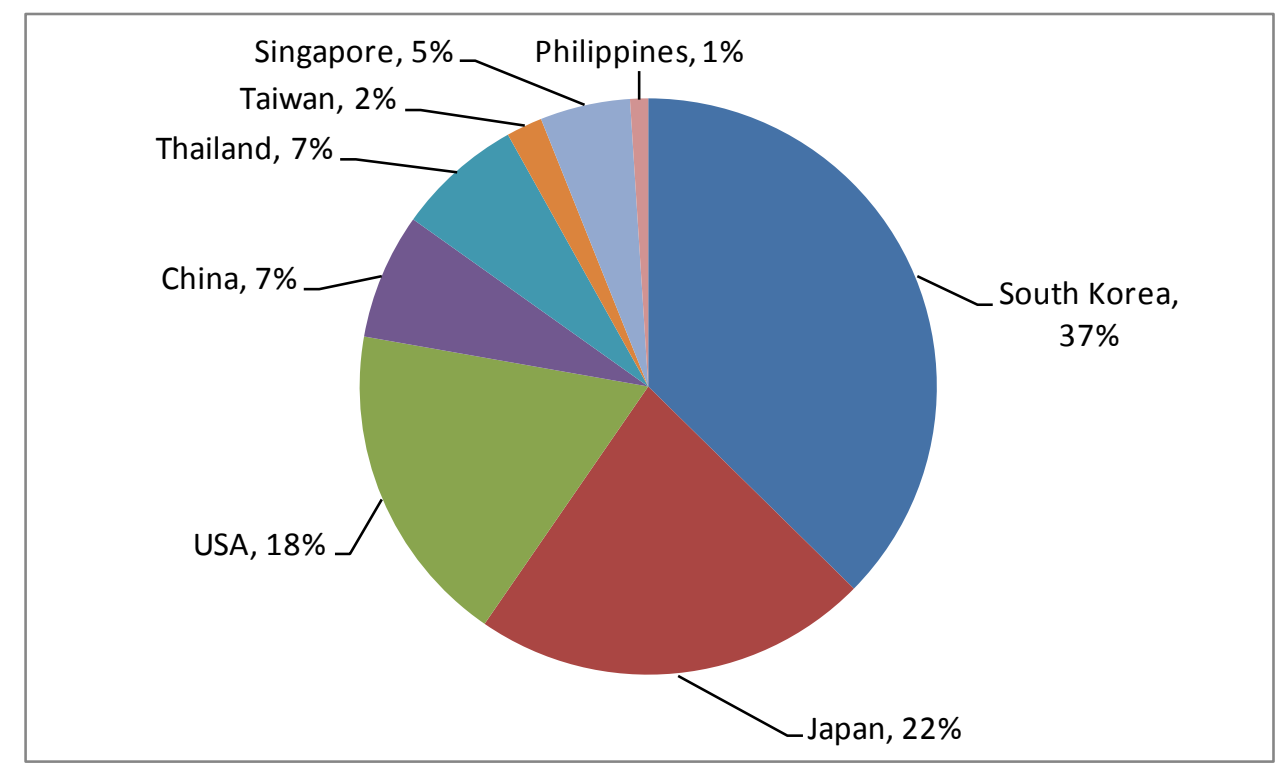

Source: Platts

It would therefore appear that Russian ESPO crude is likely to have an important role not only in bolstering Russia's oil production and exports over the next two decades but also in providing a significant new source of oil imports for the Asia-Pacific markets. Development of East Siberia and the Far East is a strategic priority for the Russian Administration and it has now put the commercial and infrastructure incentives in place to encourage field development. It is clear that enormous reserves are already available for exploitation, with production growing fast enough to fill the 1 million bpd capacity of ESPO Phase 2 by 2014 if current plans are met. Beyond that, the development of the third phase of the pipeline system to a capacity of 1.6 million bpd would appear to be justified on the conservative assumption that only a minimal level of extra exploration success is achieved over the next decade (see Figure 26). As such the development of Russia's oil resources in East Siberia and the Far East might not only provide it with a replacement for declining sales in the West, but can also potentially provide Asia-Pacific markets with a source of supply diversification. An analysis of whether ESPO crude can become a significant new crude benchmark in the region is beyond the scope of this study, and will depend upon political, commercial and geological factors impacting the development of Russia's eastern regions over the next few years. However, it is possible that over the next decade, given appropriate corporate investment, government support and market access, Russian ESPO crude could provide a challenge to the dominance of Middle Eastern crude in the Asia-Pacific region. 


\section{Appendix 1: Definitions of East Siberia and Far East of Russia}

Geographically Eastern Siberia is generally regarded as stretching from the Pacific Coast in the East to the Yenisei River system in the West, effectively covering the whole of mainland Russia to the east of the Yamal Nenets Autonomous Okrug (the heartland of West Siberia). ${ }^{97}$ However, this general definition does not fit exactly with the economic and political regions established by the Russian Administration. Indeed in a political sense East Siberia does not actually exist as an entity, as all the geographical territory of Eastern Russia is covered within the Siberian and Far East Federal Districts (see Map A-1)

\section{Map A-1: The Seven Federal Districts in Russia}

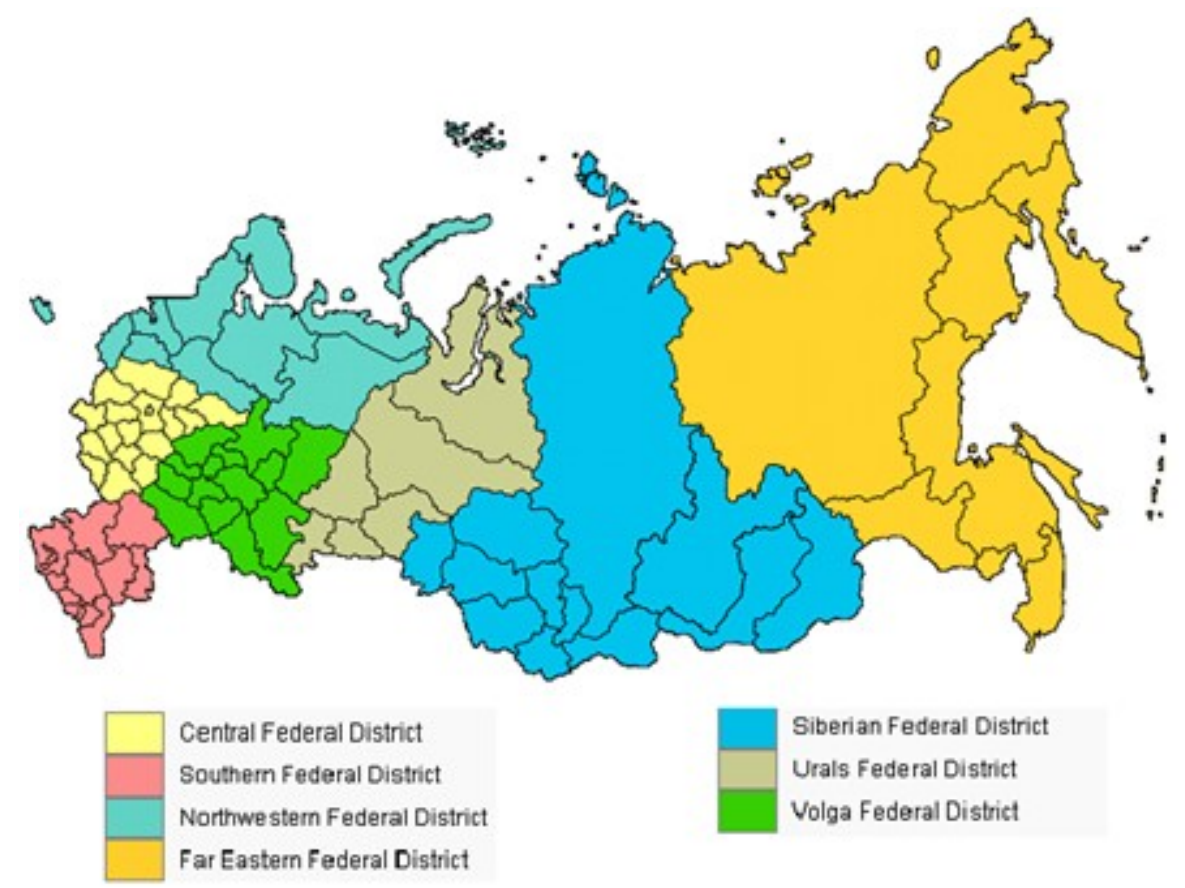

Source: Gusev, 2010

However, the more detailed division of Russia into twelve economic regions does recognise East Siberia as a separate area, covering the Republics of Buryatia, Tyva and Khakassia as well as Krasnoyarsk Krai and the Oblast of Irkutsk and Chitinsk. The Far East region is then defined as the Republic of Sakha, the Krais of Primorsk and Khabarovsk and the Oblasts of Amur, Kamchatka, Magadan and Sakhalin (see Map A-2).

\footnotetext{
${ }^{97}$ The School of Russian and Asian Studies at http://www.sras.org/eastern_siberia, accessed on January $19^{\text {th }}$ 2011
} 


\section{Map A-2: The 12 Economic Regions of Russia}

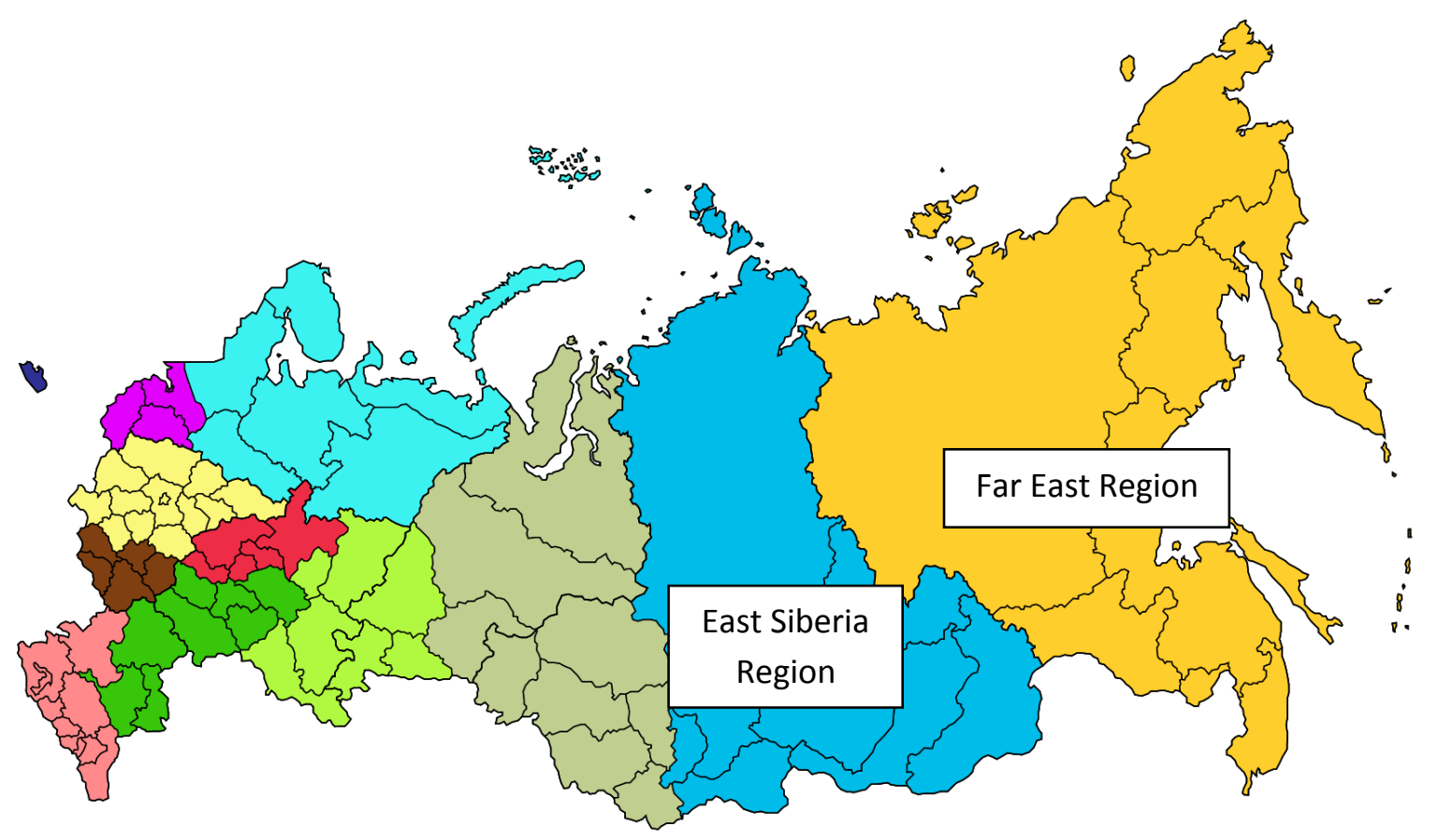

In terms of defining the two areas from an oil and gas industry perspective, most of the fields described in this analysis fit into this economic definition of East Siberia. Rosneft's Vankor field is in the East Siberian region of Krasnoyarsk as are all the fields and licences in the Yurubcheno Takhomskoye area. TNK-BP's Verkhnechonskoye field and the surrounding licences are in the Irkutsk Oblast, again in East Siberia, and all of Irkutsk Oil's assets are also (not surprisingly) in the same area. Meanwhile the Sakhalin fields and licences are quite clearly in the Far East region, as are the new licences that have been issued offshore Magadan and Kamchatka.

There are only two anomalies in terms of the regional definitions. The first, and most immediately important, is the location of the Sakha (Yakutia) region, which is strictly in the Far East but is generally referred to as being in East Siberia. Surgutneftegas, the main producer in the region at its Talakanskoye field, refers generally to all its assets in the area as being in East Siberia (Surgutneftegas, 2010), and it is interesting that Rosneft also refers to the Republic of Yakutia as being located in East Siberia (Rosneft, 2006). As a result, when the locations of fields or assets in Sakha are referred to in this analysis, they are treated as being in East Siberia rather than in the Far East region.

A second anomaly is the treatment of the oil fields referred to by TNK-BP and Slavneft as their Yamal projects. Technically these fields are located on the border of the Yamal-Nenets 
and Krasnoyarsk regions, and their geology is in reality linked to the fields of West Siberia. However, this tectonic definition is also true of the Vankor field, which is generally regarded as an East Siberian asset, and the proximity of the Messoyakha, Suzun and Tagul fields owned by TNK-BP and Slavneft to the Vankor field encourages their inclusion in an analysis of East Siberia. The fields are likely to be linked into the Vankor-Purpe pipeline system, or will have their own direct link to Purpe and from there to the ESPO and on into the Asian markets. Interestingly the Suzun and Tagul fields have also been included in the list of 22 East Siberian fields that are eligible for tax exemptions, and so even the Russian Administration is prepared to stretch its definition of East Siberia in this case (see Table 3 above).

In conclusion, this paper defines fields in East Siberia in a rather loose fashion, to include assets in the six republics or oblasts that make up the East Siberia economic region as well as fields that may in future be linked into the Vankor pipeline system to the ESPO. East Siberia is also defined as including the Republic of Sakha (Yakutia), while the Far East is defined as any republic to the east of this, and most importantly is dominated by the oil and gas fields found on and around Sakhalin Island.

\section{Appendix 2: Reserve Classification in Russia}

Russian methodology for defining reserves differs from that used by the international oil industry. Reflecting its Soviet origins, the system pays less attention to profitability than to technical feasibility (IEA, 2002, pp. 70-71). Russian nomenclature designates different reserve categories in descending order of geological certainty, reflecting the degree of exploration that has occurred. "Explored reserves" are the sum of Russian categories A, B, and $\mathrm{C}$, while "proven reserves" are the sum of categories A, B and a subset of C referred to as $\mathrm{C} 1(\mathrm{~A}+\mathrm{B}+\mathrm{C} 1)$. Well-test or $\log$ data are required for reserves certified as $\mathrm{C} 1$ or higher. $\mathrm{C} 2$ reserves are typically extensions of proven fields. C3/D0 "reserves" are based only on seismic data, while D1 and D2 are speculative estimates of unsurveyed prospects in proven or unproven petroleum provinces. The key differences between the Russian and international methodologies are shown in Figure A2-1 below: 
Table A-1: Key differences between Russian and international reserve methodologies

Soviet Reserve Classification

\section{Explored / Commercial Reserves}

$A+B+30 \%$ of $C 1$

A Geologically and geophysically examined Delineated by exploration \& production Engineering data show recoverability Represent reserves in current production

B Geologically and geophysically examined Evaluated by adequate drilling Engineering data show recoverability Represent unused producing capacity

C1 (30\%) Reserves adjacent to A and B categories Geologically and geophysically examined Verified by minimal drilling Engineering data show recoverability ( $30 \%$ will shift to $B$ and then $A$ categories)

\section{Prospective Reserves}

$70 \%$ of $C 1+C 2+D 1+D 2$

\section{C1 (70\%) As above}

C2 Presumed to exist, based on favourable geologic and geophysical data analagous to that of verified reserves

D1 Speculative reserves presumed to exist, based on geologic analogy to reference areas

Some will shift to C2 category

D2 Speculative reserves presumed to exist, based on geologic analogy to reference areas

Less evaluated than D1 Some will shift to D1 category

\section{Western Reserve Classification}

\section{Proved}

Reserves which geological and engineering or drilling data demonstrate to be recoverable under existing economic and operating conditions

\section{Probable}

Incompletely defined reserves estimated to occur: In known producing areas / extensions of endowed areas

In undiscovered areas within known resource-bearing geologic trends

Recoverable under existing economic and operating conditions

\section{Possible}

Inferred reserves estimated to occur

In undiscovered areas analogous to other known resource-bearing geologic trends

Recoverable under existing economic and operating conditions

Source: IEA Russia Energy Survey 2002 


\section{Bibliography}

Allen, S., \& Henderson, J. (2001). Yukos: Growth Prospects Outweigh Risks. Moscow: Renaissance Capital.

Barbajosa, A. (2010). Russia raises eyebrows with inroads of ESPO crude. Singapore: Reuters.

Bradshaw, M. J. (2006). Sakhalin 2 In The Firing Line. London: Russian Analytical Digest.

Burgansky, A. (2008). Urals Energy: Funding Concerns. Moscow: Renaissance Capital.

Butlin, M. (2010). Urals Energy: Major re-rating potential. London: Allenby Capital.

Davletshin, I. (2011). Russian oil sector taxation: The fiscal saga; end of Part One. Moscow: Renaissance Capital.

EIA. (2010b). China Brief. Washington: Energy Intelligence Agency.

EIA. (2010a). International Energy Outlook. Washington: EIA.

EIA. (2008). Sakhalin Brief. Washington: EIA.

Gusev, A. (2010). RegionalEconomic Inequality: Impact on Economic Growth and its Optimal Value in Russia. Sochi: Krasnodar Region Investment Forum.

Huasheng, Z. (2010). Sino-Russian Relations 2009-2010: A Perspective from China. Russian Analytical Digest 73/10, 5-8.

IEA. (2002). Russia Energy Survey 2002. Paris: International Energy Agency.

Itoh, S. (2010). Sino-Russian Energy Relations: True Friendship or Phony Partnership? Russian Analytical Digest 73/10 , 9-12.

Kokin, A. (2010). GazpromNeft: Fair Value Decrease. Moscow: Metropol Investment.

Minina, O. (2007). Pipelines of East Siberia: From Local Supplies to Large-Scale Exports. Pipeline and Gas Journal , 60-69.

Moshkov, M. (2010). Taxable production lower, oil taxes higher. Moscow: UBS.

Olcott, M. B., \& Petrov, N. (2009). Russia's Regions and Energy Policy in East Siberia. Houston: James Baker III Institute for Public Policy \& The Institute of Energy Economics, Japan.

Platts. (2009). Russian crude oil exports to the Far East - ESPO starts flowing. New York: McGraw Hill.

Platts. (2010). Russian crude oil exports to the Pacific Basin - ESPO starts flowing. New York: McGraw-Hill. 
Platts. (2010). Russia's ESPO Crude Oil Gains Acceptance as a Key Asia-Pacific Reference. New York: Platts Analysis.

Portyakov, V. (2010). Russian-Chinese relations: Current trends and future prospects. Russian Analytical Digest 73/10 , 2-4.

Poussenkova, N. (2008). All Quiet on the Eastern Front. Russian Analytical Digest 33 , $13-$ 18.

Poussenkova, N. (2006). Lord of the Rigs: Rosneft as a Mirror of Russia's Evolution.

Moscow: Carnegie Moscow Center.

Poussenkova, N. (2007). The Wild Wild East. Moscow: Carnegie Endowment for International Peace.

Reed, A. (2010, August 24). Growing Premium for Russian Crude. CISWatch .

RF Ministry of Energy. (2009). Russian Energy Strategy to 2030. Moscow: Government of the Russian Federation.

Rosneft. (2010). Annual Report 2009. Moscow: Rosneft.

Rosneft. (2011). Full Year 2010 Financial Results Presentation. Moscow: Rosneft.

Rosneft. (2006). Rosneft President Sergey Bogdanchikov Visits China as part of a Russian Govt Delegation. Moscow: Rosneft.

Slavneft. (2010). Annual Report 2009. Moscow: Slavneft.

Surgutneftegas. (2010). Annual Report 2009. Moscow: Surgutneftegas.

TNK-BP. (2008). Far Eastern Express. Moscow: TNK-BP.

TNK-BP. (2010). Investor Presentation November 2010. Moscow: TNK-BP.

Uralsib. (2010). Rosneft: Vankor Field Visited. Moscow: Uralsib. 